\author{
UNIVERSIDADE DE SÃO PAULO \\ FACULDADE DE ZOOTECNIA E ENGENHARIA DE ALIMENTOS
}

\title{
LAURA LIMA SOARES
}

Gestão da qualidade em cooperativas leiteiras e laticínios: um estudo de caso do programa Qualileite da Danone 


\section{LAURA LIMA SOARES}

Gestão da qualidade em cooperativas leiteiras e laticínios: um estudo de caso do programa Qualileite da Danone

\section{Versão Corrigida}

Dissertação apresentada à Faculdade de Zootecnia e Engenharia de Alimentos da Universidade de São Paulo, como parte dos requisitos para a obtenção do título de Mestre em Ciências do programa de Mestrado Inovação da Indústria Animal.

Área de Concentração: Gestão e Inovação da Indústria Animal.

Orientador: Profa ${ }^{a}$ Dra . Fabiana C. V. Leonelli 
Ficha catalográfica elaborada pelo Serviço de Biblioteca e Informação, FZEA/USP, com os dados fornecidos pelo(a) autor(a)

Lima Soares, Laura Laticínios: um estudo de caso do programa Qualileite da Danone / Laura Lima Soares ; orientadora Fabiana C. V. Leonelli. -- Pirassununga, 2016. $92 \mathrm{f}$.

Dissertação (Mestrado - Programa de Pós-Graduação em Mestrado Profissional Gestão e Inovação na Indústria Animal) -- Faculdade de Zootecnia e Engenharia de Alimentos, Universidade de São Paulo.

1. GESTÃO DA QUALIDADE. 2. QUALIDADE DO LEITE. 3. CADEIA DE SUPRIMENTOS. 4. PDCA. 5. INSTRUÇÃO NORMATIVA $\mathrm{N}^{\circ}$ 62. I. C. V. Leonelli, Fabiana, orient. II. Título. 
SOARES, L. L. Gestão da qualidade em cooperativas leiteiras e Laticínios: um estudo de caso do programa Qualileite da Danone. 2016. 92 f. Dissertação (Mestrado) - Faculdade de Zootecnia e Engenharia de Alimentos, Universidade de São Paulo, Pirassununga, 2016

Aprovada em: 15/08/2016

\section{Banca Examinadora}

Profa. Dra. Fabiana C. V. Leonelli Instituição: FZEA USP

Orientador

Julgamento: Aprovado

Dr Laerte D. Cassoli

Instituição: Clínica do Leite

Julgamento: Aprovado

Prof ${ }^{a}$. Dr ${ }^{\text {a }}$ Vivian Larados Santos Silva

Instituição: FZEA USP

Julgamento: Aprovado 


\section{Agradecimentos}

Agradeço a Deus por me proporcionar discernimento para buscar conhecimento, com foco e determinação;

Minha família por todo apoio para atingir mais um objetivo, em especial meus avós Rosires e Odette, Vó Lia, Bruno e Cláudio;

Meu noivo Lincoln que sempre incentiva e colabora na superação de todos os obstáculos;

Em memória ao meu pai João Victor Fasano Soares por sempre ter me incentivado a ler, estudar e vencer;

Ao departamento de aprovisionamento do leite da Danone, especificamente ao Roberto Costa que possibilitou o desenvolvimento do Qualileite;

Às Cooperativas Corples e Coopas, em especial a Elaine, Manir, Wellington, Venicio e Bruna que tiveram sucesso e evolução nos resultados da qualidade na cadeia de leite.

A minha orientadora $\operatorname{Prof}^{a} \operatorname{Dr}^{a}$ Fabiana Leonelli por todo apoio, motivação e aprendizagem que me proporcionou durante o mestrado;

E a Universidade de São Paulo pela qualidade do ensino e o rigor exigido para a obtenção de cada título, fator que faz com que seus estudantes deem mais valor em sua formação. 


\section{Dedicatória}

Dedico este trabalho a minha mãe Rosália Campos de Lima que sempre me incentivou a estudar, estudar e estudar. Diante de todas as dificuldades venci mais uma conquista. O estudo é o bem mais valioso que podemos levar para o resto de nossas vidas. 


\section{RESUMO}

SOARES, L. L. Gestão da qualidade em cooperativas leiteiras e Laticínios: um estudo de caso do programa Qualileite da Danone. 2016. 92 f. Dissertação (Mestrado) - Faculdade de Zootecnia e Engenharia de Alimentos, Universidade de São Paulo, Pirassununga, 2016

O aumento do rigor na aplicação da Instrução Normativa 62 (IN 62) estabelecido pelo Ministério da Agricultura, Pecuária e Abastecimento (MAPA) desde 2011, aliado à demanda por leite de qualidade pelas indústrias e consumidores, tem motivado esforços de toda a cadeia produtiva do leite, no sentido de elevar o patamar de qualidade do produto. Sendo assim, objetivo deste trabalho é aprimorar a gestão da qualidade em cooperativas fornecedoras de leite à planta industrial da Danone, localizada em Poços de Caldas - MG, proporcionando melhores resultados de qualidade e, sobretudo, atendimento às exigências da IN 62. Para isso, foram traçados planos de ações pautados na metodologia "Planejar, Fazer, Verificar e Agir" (sigla em Inglês PDCA), direcionados para a melhoria dos procedimentos e processos, no qual envolvem a qualidade do leite da cooperativa fornecedora, de modo a obter melhorias nos indicadores da qualidade do leite de toda a cadeia de captação da empresa fornecedora até a recepção na Danone. A partir da verificação dos resultados práticos da aplicação da metodologia de gestão da qualidade do leite, foram analisados os pontos críticos de todas as etapas do leite desde os produtores, transportadores, recepção e resfriamento na cooperativa. Além disso, uma efetiva comunicação, alinhamento e qualificação dentre os responsáveis pela captação e qualidade do leite foi proposta, visando diminuir problemas de falta de comunicação. Este trabalho contribuiu na superação dos desafios diante das ineficiências do processo, pois propôs ações efetivas de melhoria da gestão da qualidade das cooperativas, refletindo em melhores resultados de Contagem Bacteriana Total na recepção de leite da Danone.

PALAVRAS-CHAVE: Instrução Normativa 62, leite, PDCA, cadeia de suprimentos, fornecedores. 


\begin{abstract}
SOARES, L. L. Quality management in dairy and Dairy cooperatives: a case study of Qualileite Danone project. 2016. 92 f. Dissertação (Mestrado) - Faculdade de Zootecnia e Engenharia de Alimentos, Universidade de São Paulo, Pirassununga, 2016

The increased rigor in the application of normative Instruction 62 (IN 62) established by the Ministry of Agriculture, Livestock and Supply (MAPA) since 2011, coupled with the demand for quality milk by industries and consumers have motivated efforts inside of milk production chain in order to raise the quality level of the product. Thus, the aim of this work is to improve the milk quality management of cooperatives that supply milk for Danone factory located in Pocos de Caldas - MG. Ìn order to get better quality results and, above all, comply with the requirements of IN 62, action plans were drawn up based on PDCA (Plan, Do, Check, Act) methodology to improve the processes that involve the quality of milk in the cooperative supplier and achieve better quality indicators throughout the chain, since the milk producer until Danone. Based on verification of the practical results of applying milk quality management methodology, critical points were analyzed in all stages of milk since the producers, transporters, reception and cooling in the cooperative. In addition, effective communication, alignment and qualification among those responsible for the collection and quality milk has been proposed in order to reduce problems of miscommunication. This work contributed in overcoming the challenges over inefficient processes proposing effective actions to improve the quality management of cooperatives, reflecting better results of Total Bacterial Count in Danone Milk reception.
\end{abstract}

KEYWORDS: Instruction 62, milk, PDCA, supply chain, suppliers. 


\section{LISTA DE FIGURAS}

Figura 1- Produção anual de Leite no Brasil. ........................................................13

Figura 2-Concentração da produção de leite nas regiões do Brasil........................14

Figura 3 - "Linha do Tempo" da construção da qualidade do leite no Brasil.............22

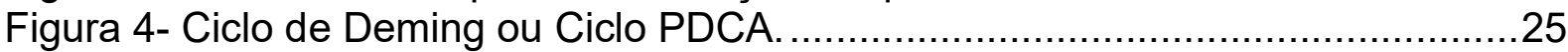

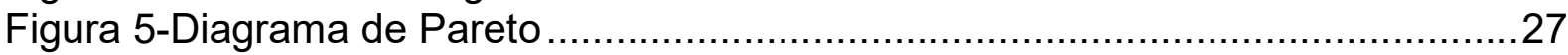

Figura 6-Diagrama de Pareto aplicado no controle da qualidade do leite ................28

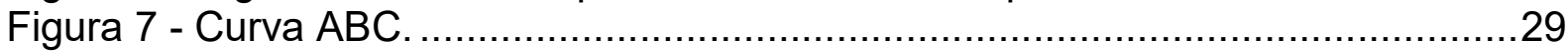

Figura 8-Diagrama de Ishikawa ou Espinha-de-peixe............................................

Figura 9-Diagrama de Causa e Efeito no estudo de caso de fatores de risco da CBT

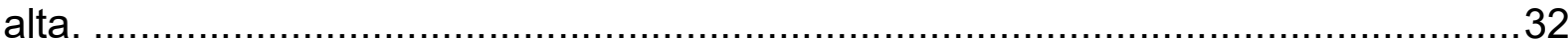

Figura 10- Principais componentes e objetivos da boas práticas de produção de leite.

Figura 11 - Árvore decisória usada para a identificação dos PCC's........................52

Figura 12 - Etapas do trabalho de campo .....................................................56

Figura 13 - Abordagens metodológicas utilizadas na pesquisa............................56

Figura 14 - Passo-a-passo de implementação do programa..................................60

Figura 15 - Segregação do leite em rotas que vão direto para a Danone..................62

Figura 16 - Transferência do leite segregado para caminhões que vão direto para a

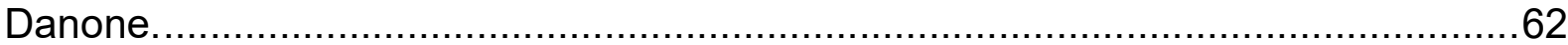

Figura 17- Segregação do leite de rotas em silos específicos ..............................63

Figura 18 -\% do volume de leite provido de cooperativas na recepção Danone com

CBT < 300.000 UFC/mL em 2014 .................................................................69

Figura 19 - \% do volume de leite provido de cooperativas na recepção Danone com

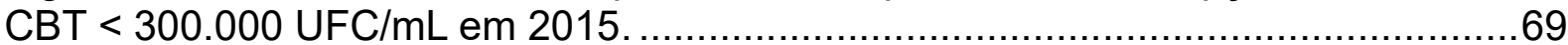

Figura 20 - Média Geométrica Trimestral CBT Produtores Corples ........................71

Figura 21 - Indicador CBT Corples em 2012 com o inicio do Qualileite em junho.....72

Figura 22 - Indicador CBT Corples de 2012 à abril de 2016 na recepção de leite

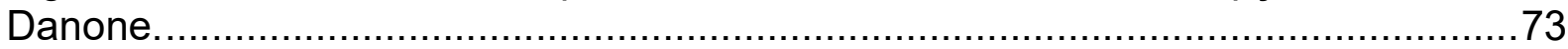

Figura 23 - Média Geométrica Trimestral CBT Produtores Coopas .........................75

Figura 24 - Indicador CBT COOPAS de 2012 a 2015 na recepção de leite Danone.76

Figura 25 -Indicador CBT Coopas em 2014 com o início do Qualileite em junho. ....77

Figura 26 - Média Geométrica Trimestral CBT Produtores Cooperativa X" ................78

Figura 27 - Indicador CBT Cooperativa "X" 2014, com início do Qualileite em março.

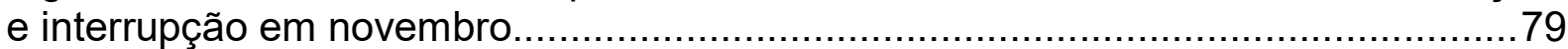

Figura 28 - Porcentagem de ações não cumpridas diante das estabelecidas nos

primeiros seis meses do programa 


\section{LISTA DE TABELAS}

Tabela 1- Requisitos microbiológicos, físicos, químicos, de CCS, de resíduos químicos do Leite Cru Refrigerado.

Tabela 2 - Requisitos Físicos e Químicos em Leite Cru Refrigerado a serem avaliados pela RBQL.

Tabela 3 - Exigências na qualidade do Leite Cru Refrigerado.

Tabela 4 - Plano de Ação com objetivo de Redução na CBT (contagem Bacteriana total) do leite de produtores.

Tabela 5 - Características das cooperativas participantes do programa Qualileite...57 


\section{LISTA DE QUADROS}

Quadro 1 - Determinação de perigos e pontos críticos de controle do processamento do leite pasteurizado. .............................................................................54 Quadro 2 - Mapa descritivo dos pontos críticos de controle do processamento de ..55 Quadro 3 - Check-List de ações e passos do Qualileite. 82 Quadro 4: Respostas das cooperativas ao questionário de avaliação do programa. Continua. 


\section{SUMÁRIO}

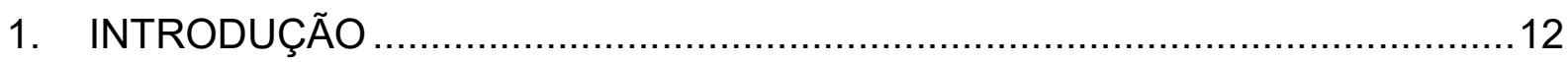

1.1. Contextualização do Problema de Pesquisa: O programa Qualileite da

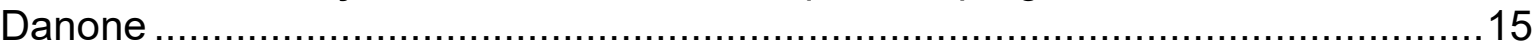

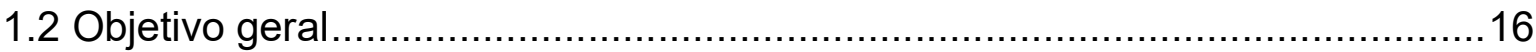

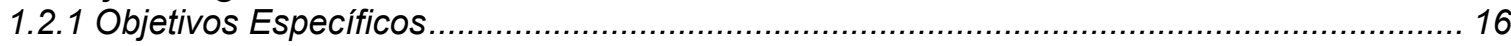

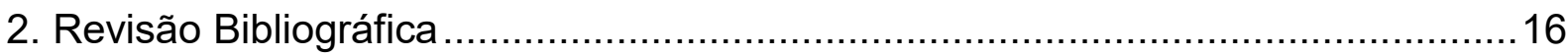

2.1. Histórico da legislação da Qualidade do Leite no Brasil ..............................16

2.1.1 A Instrução Normativa 51 (2002) ........................................................................... 18

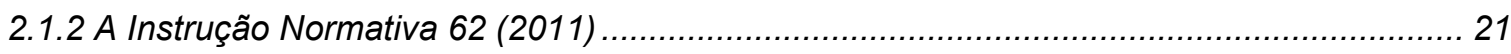

2.2 Gestão da Qualidade ..................................................................23

2.2.1 A Importância da Gestão da Qualidade na Cadeia de Lácteos ........................................ 23

2.2.2 Ferramentas da Gestão da Qualidade....................................................................... 24

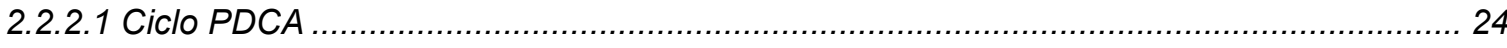

2.2.2.2 Diagrama de Pareto ............................................................................................... 27

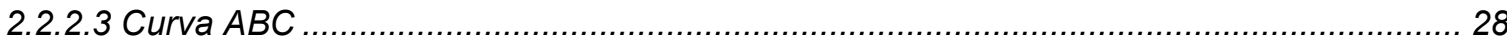

2.2.2.4 Diagrama de Causa e Efeito........................................................................................ 29

2.2.2.5 Planos de ação e análise: 5 Ws e $2 \mathrm{Hs}$............................................................. 32

2.2.2.6. Método de Análise e Solução de Problemas (MASP) ............................................... 33

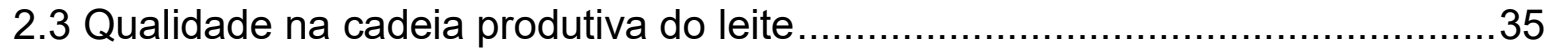

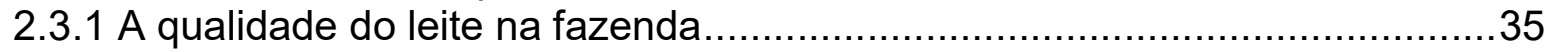

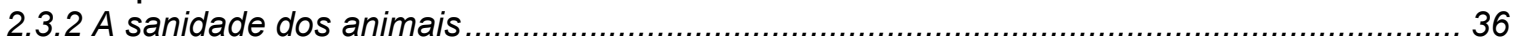

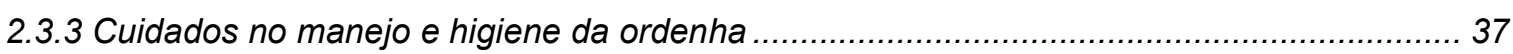

2.3.4 Manutenção preventiva da ordenha mecânica................................................................ 39

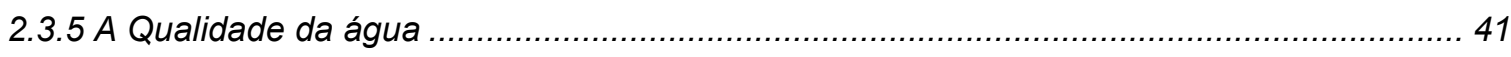

2.3.6 Limpeza do equipamento de ordenha, utensilios e tanque ............................................. 41

2.3.7 Tipos de microrganismos e a importância da cadeia de Frio ............................................. 44

2.3.8 A Qualidade do Leite no Transporte ....................................................................... 46

2.3.9 O Controle da Qualidade do Leite Cru Refrigerado na Recepção ..................................... 48

2.3.10 Garantia da Qualidade do Leite na Indústria ou Usina de Beneficiamento do Leite.......... 48

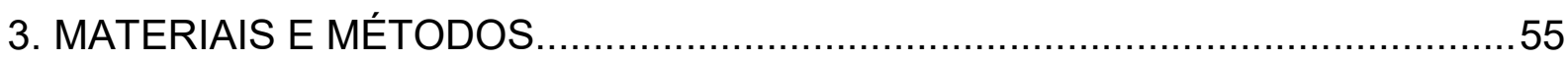

3.1 Descrição das cooperativas participantes do Programa Qualileite ..................56

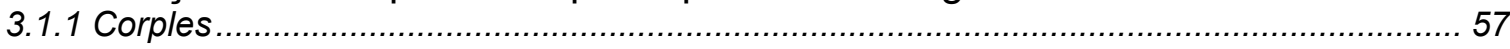

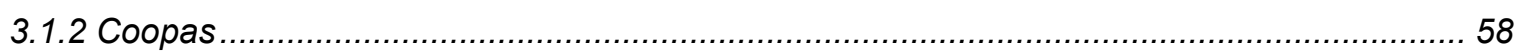

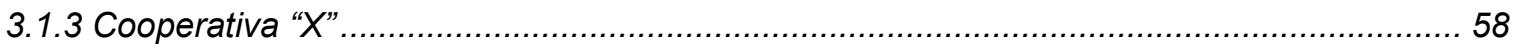

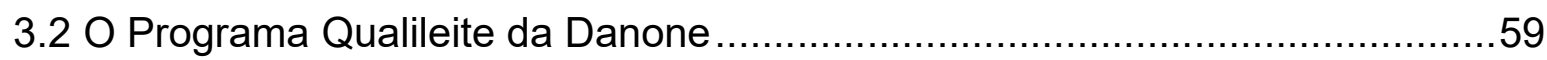

3.3 Implementação do Programa Qualileite..................................................6

3.3 Análise quantitativa dos resultados ........................................................65

3.4 Análise qualitativa do Qualileite ...........................................................67

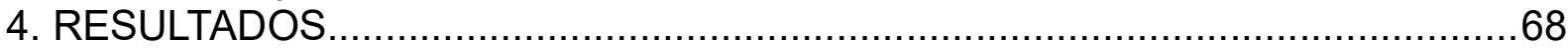

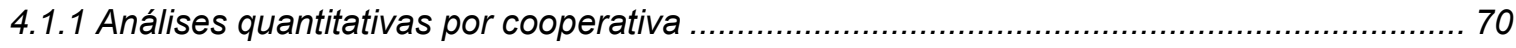




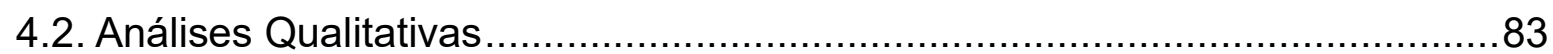

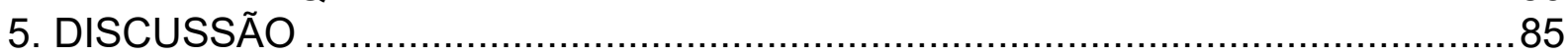

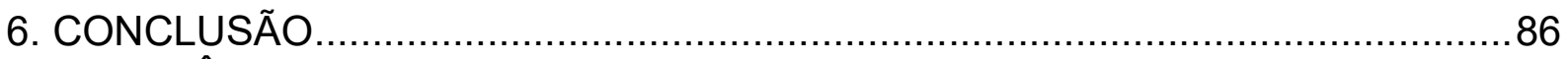

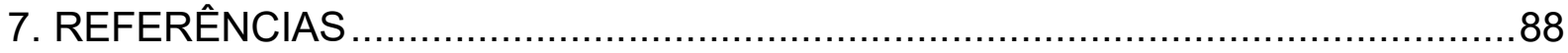




\section{INTRODUÇÃO}

O leite é um alimento rico em nutrientes essenciais para o crescimento, desenvolvimento e a manutenção de uma vida saudável. É considerado um alimento nobre, pois apresenta composição rica em proteínas, vitaminas, gorduras, carboidratos e sais minerais essenciais para o ser humano.

A produção e composição do leite de vaca são influenciadas por vários fatores como raça, genética, estágio de lactação, número de lactações e fatores ambientais como clima, fatores patológicos e fisiológicos, fração da ordenha, ou seja, $1^{\mathrm{a}}, 2^{\mathrm{a}}$ ou $3^{\mathrm{a}}$ ordenha do dia, e fatores nutricionais. Geralmente, a composição média do leite de vaca está assim distribuída: $87,4 \%$ de água e 12,6\% de Extrato Seco Total (EST), sendo $3,9 \%$ de gordura; $3,2 \%$ de proteína; $4,6 \%$ de lactose; e $0,9 \%$ de minerais diversos (HARDING, 1995).

Em 1992, o Departamento de Agricultura dos Estados Unidos (United States Departmant of Agriculture - USDA) desenvolveu a Pirâmide Alimentar a fim de conscientizar a população de uma maneira didática, a adotar uma dieta equilibrada e saudável. Nesta Pirâmide, recomenda-se o consumo de três porções de leite e produtos lácteos ao dia (PHILIPPI et al., 1999).

No que diz respeito à demanda por lácteos, de acordo com Hemme et al (2010), de 2003 a 2010 houve ascensão no consumo, com variação média de $3,7 \%$ ao ano, atingindo 159 litros/habitante/ano em 2010. De 2010 a 2015 este crescimento foi reduzido, ou seja, em média de 1,9\% atingindo os 174 litros/habitante/ano em 2015 (RABOBANK, 2015 apud ROCHA, 2015). A perspectiva da demanda será retração do consumo em 2016 para 171 litros/habitante/ano devido à situação econômica atual com desemprego crescente e inflação em alta, voltando a crescer somente em 2018 de forma gradual para 173 litros/habitante/ano (RABOBANK, 2015 apud ROCHA, 2015).

Diante do cenário da demanda de lácteos, o consumo médio por pessoa ainda está abaixo do ideal, pois o Ministério da Saúde recomenda que o consumo esteja entre 200 e 210 litros/habitante/ano. A União Europeia, por exemplo, tem consumo de leite maior que 291 litros/habitante/ano (EMBRAPA, 2010), devido à cultura de grande consumo de lácteos em todas as faixas etárias. Diante disso, encontram-se oportunidades para o Brasil aumentar cada vez mais a demanda por lácteos. 
Consequentemente, consumidores, indústrias e a legislação se tornam cada vez mais exigentes para a garantia da qualidade dos alimentos. A indústria deve manter um padrão de qualidade sensorial, nutricional e com biossegurança adequada para o abastecimento e consumo de seus clientes. Com isso, toda a cadeia de suprimentos deve ser monitorada, rastreada e certificada desde sua produção até o produto acabado, a fim de garantir a qualidade do produto (ABNT, 2006).

A produção de leite no Brasil está em constante crescimento, segundo dados do Instituto Brasileiro de Geografia e Estatística (Figura 1) (IBGE, 2014), a produção cresceu em média 4\% ao ano entre 2004 até 2014, atingindo a marca de 35,17 bilhões de litros de leite em 2014. Com este dado, o Brasil ocupou a quinta posição no ranking mundial de produção de leite em 2014, atrás da União Europeia, Índia, Estados Unidos e China (USDA, 2014).

Figura 1- Produção anual de Leite no Brasil.

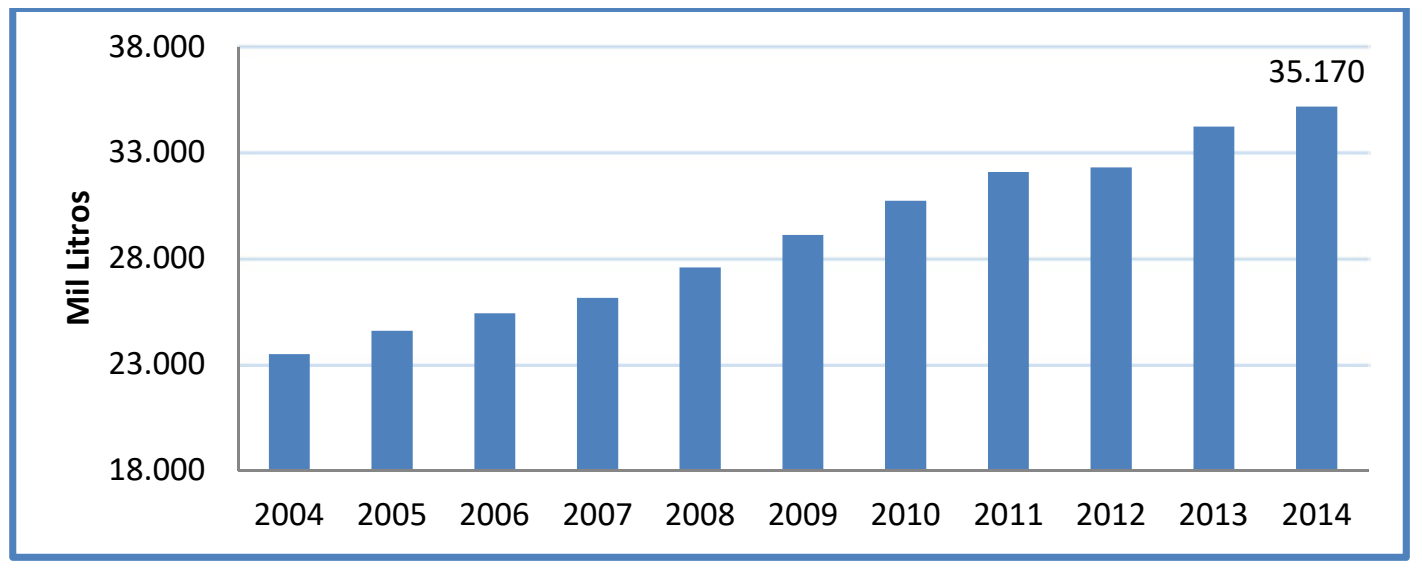

Fonte: INSTITUTO BRASILEIRO DE GEOGRAFIA E ESTATÍSTICA. Quantidade de Leite Total. IBGE, 2014.

A produção de leite no Brasil em 2014, pela primeira vez, se concentrou na região Sul com uma ligeira diferença sobre a região Sudeste, representando $34,7 \%$ da produção, ou seja, aproximadamente 12,2 bilhões de litros, seguida pela região Sudeste com 12,17 bilhões (34,6\% do total). O Centro-Oeste respondeu por $14,1 \%$ (com 4,96 bilhões de litros), a região Nordeste, 11,1\% (com 3,9 bilhões de litros) e a região Norte com $5 \%$ do total (1,9 bilhões de litros) (Figura 2) (IBGE, 2014). 
Figura 2-Concentração da produção de leite nas regiões do Brasil.

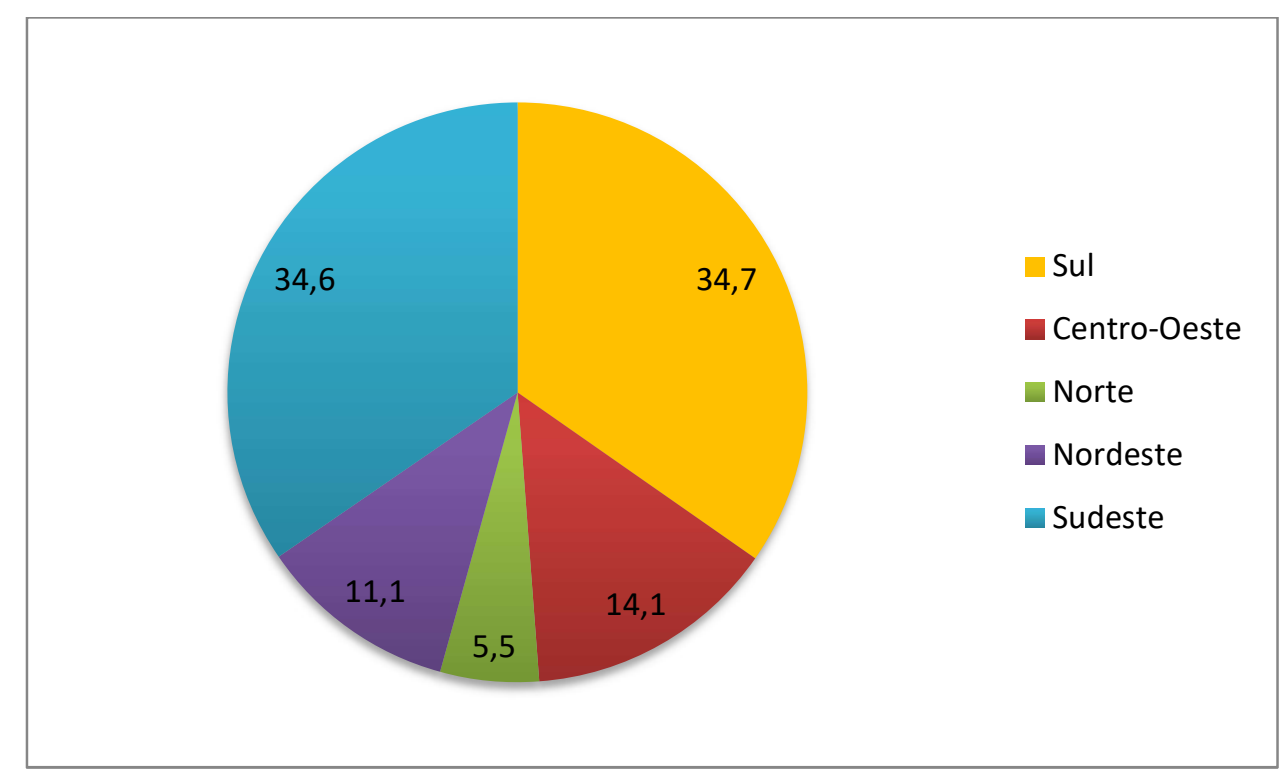

Fonte: INSTITUTO BRASILEIRO DE GEOGRAFIA E ESTATÍSTICA. Quantidade de Leite Total. IBGE, 2014.

De acordo com levantamento realizado pela Embrapa Gado de Leite (2009), o agronegócio do leite e seus derivados desempenham um papel relevante no suprimento de alimentos e na geração de emprego e renda para a população brasileira. O país tem em torno de 1,1 milhões de propriedades rurais que exploram a atividade leiteira, garantindo mão-de-obra direta na atividade de 3,6 milhões de pessoas. Em termos de geração de emprego, o agronegócio do leite é responsável por $40 \%$ dos postos de trabalho no meio rural.

Apesar da evolução em volume de leite produzido e da importância econômica da atividade leiteira, 91,5\% dos produtores no Brasil possuem uma produção inferior a 100 litros leite/dia (IBGE, 2011). Estes produtores representam 47\% do volume total produzido e são classificados pela Embrapa Gado de Leite como Produção de Subsistência. Com isso, a produtividade no Brasil ainda está inferior a países de destaque na produção de leite com apenas 4 litros/vaca/dia enquanto os Estados Unidos, por exemplo, atingem 26 litros/vaca/dia (FAO, 2013). O aumento da produtividade se dá por meio da adoção da tecnologia, conhecimentos técnicos e de gestão e organização na produção de leite.

Neste sentido, fomentar o aumento da produtividade e da qualidade do leite produzido no Brasil deve ser foco de ações governamentais e de empresas atuantes no setor, como é o caso da Danone. 


\subsection{Contextualização do Problema de Pesquisa: O programa Qualileite da Danone}

A Danone é uma multinacional de origem Francesa, líder mundial em produtos lácteos frescos e vice-líder em águas, nutrição infantil e hospitalar. Segundo o ranking das maiores empresas de laticínios do Brasil em 2014, divulgado pela LEITE BRASIL - Associação Brasileira dos Produtores de Leite (2015), a Danone ficou em $8^{\circ}$ lugar com capitação total de 518 bilhões de litros de leite em 2014. Deste volume, $65 \%$ são de Produtores integrados à Danone e 35\% de terceiros (cooperativas e laticínios). Segundo esta mesma pesquisa, a média de produção diária dos produtores da Danone é 1.564 litros de leite por dia, por outro lado, os produtores dos fornecedores terceiros da Danone têm um perfil caracterizado por baixa adoção tecnológica e, consequentemente, uma baixa produção diária, ou seja, em média 185 litros de leite por dia.

Com a missão de levar saúde e nutrição para o maior número de pessoas, a Danone tem se preocupado em obter sua principal matéria-prima com parâmetros satisfatórios para o controle de qualidade, atendendo assim as exigências da Instrução Normativa $\mathrm{n}^{\circ} 62$ (IN 62) que, desde 2011, tem aumentado o rigor para Contagem Bacteriana Total (CBT) e Contagem de Células Somáticas (CCS).

O objetivo da Danone é atender o limite de CBT em 300.000 UFC/mL na recepção de leite e, para que isto aconteça, o limite de CBT do leite coletado na fazenda é 100.000 UFC/mL. Diante disso, analisaram-se os indicadores da qualidade da CBT dos caminhões das cooperativas na recepção de leite da Danone no ano de 2012 , os quais apenas $17 \%$ do volume atendiam ao objetivo.

Quanto à CCS, o objetivo da Danone é obter leite abaixo de 400.000 céls $/ \mathrm{mL}$ e nesta mesma amostragem de caminhões providos de cooperativas em 2012, apenas $11 \%$ do volume das cooperativas atendiam ao objetivo.

Portanto, havia um desafio em obter melhorias em CBT e CCS das cooperativas fornecedoras de leite à Danone, entretanto, naquele momento as ações foram intensificadas em obter melhores padrões de higiene que trariam melhores resultados principalmente em CBT.

Além do interesse qualitativo, a Danone buscou desenvolver ações para o aprimoramento dos seus fornecedores, atendendo aos interesses econômicos e sociais, já que as cooperativas possuem uma parcela de extrema importância à companhia, uma vez que recebem leite de pequenos produtores, dando oportunidade de difundir o conhecimento técnico a estes, a fim de tornarem competitivos no 
mercado de leite. O desafio, portanto, é propor formas de interação efetivas que tragam resultados mais objetivos, seja para a empresa, quanto para às cooperativas e seus cooperados.

Sendo assim, o programa Qualileite foi desenvolvido com o objetivo de aprimorar a gestão da qualidade em cooperativas fornecedoras de leite à planta industrial da Danone, localizada em Poços de Caldas - MG, proporcionando melhores resultados de qualidade e, sobretudo, atendimento às exigências da Instrução Normativa $\mathrm{n}^{\circ} 62$ de 2011 no quesito CBT.

\subsection{Objetivo geral}

Aprimorar a gestão da qualidade em cooperativas fornecedoras de leite à planta industrial da Danone, localizada em Poços de Caldas - MG, por meio da implantação e avaliação do Programa Qualileite da Danone.

\subsubsection{Objetivos Específicos}

- $\quad$ Avaliar a efetividade do programa Qualileite, quanto à melhoria dos indicadores de CBT dos produtores das cooperativas e da cooperativa na recepção Danone;

- Apontar conformidades e não-conformidades no atendimento às exigências de CBT da IN 62;

- $\quad$ Avaliar se houve melhorias na gestão interna das cooperativas atendidas pelo programa e no relacionamento entre a empresa e seus fornecedores.

\section{Revisão Bibliográfica}

\subsection{Histórico da legislação da Qualidade do Leite no Brasil}

Segundo Durr (2004), em 1990 foi implementada no país uma política de abertura comercial que, associada com o fim do controle estatal de preços ao produtor e ao consumidor, fez com que investimentos no negócio leiteiro passassem a ser bem mais atraentes aos grandes grupos do setor, o que desencadeou uma reorganização da agroindústria do leite. O impacto desta política afetou os diferentes elos produtivos 
da cadeia, demandando adequações de padrão produtivo e tecnológico para atender as exigências do mercado.

Em 1997, na Embrapa Gado de Leite, por iniciativas do Ministério da Agricultura Pecuária e Abastecimento (MAPA), comunidade científica e acadêmica, setores produtivos e indústrias de leite, iniciaram-se as discussões do Programa Nacional de Melhoria da Qualidade do Leite (PNQL). O PNQL é o conjunto de medidas que visam instituir e consolidar uma política nacional de incentivo à produção de leite de alta qualidade.

Em 2000, elaborou-se o projeto da Rede Brasileira de Laboratórios de controle da Qualidade do Leite (RBQL), sendo oficializado em 2002, através da Instrução Normativa 37 (IN 37).

Em 2002, com a publicação da Instrução Normativa 51 (IN 51) de 18 de setembro de 2002, foram estabelecidos critérios de qualidade que, até então, não existiam, além de instaurar a obrigatoriedade de análises de leite de produtores por todas as indústrias sob o Serviço de Inspeção Federal (SIF) pela RBQL.

Os novos parâmetros foram estipulados em 2002, entretanto, considerando o prazo necessário para adequação dos produtores e laticínios aos novos critérios, as novas exigências de qualidade estabelecidas pela IN 51 só passaram a vigorar em 2005, 3 anos após a publicação da mesma. Inicialmente, estes parâmetros foram bastante permissivos, por se tratar de um conjunto de exigências pioneiras e de total desconhecimento da grande maioria dos produtores e laticínios; todavia, continha um cronograma de redução gradual dos limites de CCS e CBT, com objetivo de atingir os níveis Europeus ${ }^{1}$.

A contagem bacteriana total (CBT) é o número de bactérias contidas no leite, cujo valor numérico é expresso em unidades formadoras de colônias (UFC) por mililitro de leite (UFC/mL). A CBT indica as condições gerais de higiene de ordenha e dos utensílios utilizados bem como da refrigeração, transporte e armazenamento do leite. A alta CBT e a produção de enzimas bacterianas causam vários prejuízos para a cadeia do leite, como alterações no sabor e odor e composição do leite e derivados e alterações no tempo de validade do leite in natura e dos produtos lácteos, tendo, portanto, um importante impacto na segurança dos alimentos.

${ }^{1}$ A título de informação, o padrão Europeu é de 100.000 UFC/mL para CBT e 400.000 Céls/mL para CCS. 
A Contagem de Células Somáticas (CCS) é originada do conjunto de células de origem do sangue (linfócitos, macrófagos, e neutrófilos) e células epiteliais de escamação da própria glândula mamária presentes no leite. Essas células são um indicativo da ocorrência de inflamação intramamária e podem ser utilizadas para distinguir uma glândula mamária infectada de uma não infectada. Na glândula sadia, a contagem de células do leite é menor que 200.000 Céls/mL (SANTOS; FONSECA, 2007).

\subsubsection{A Instrução Normativa 51 (2002)}

A IN 51 foi um grande marco para a melhoria da qualidade do leite, pois aprovou os Regulamentos Técnicos de Produção, Identidade e Qualidade do Leite tipo A, do Leite tipo B, do Leite tipo C, do Leite Pasteurizado e do Leite Cru Refrigerado e o Regulamento Técnico da Coleta de Leite Cru Refrigerado e seu Transporte a Granel. Abaixo, são definidas as principais categorias de leite, segundo a IN 51:

a) Leite Pasteurizado tipo A: definido como leite classificado quanto ao teor de gordura em integral, padronizado, semi-desnatado ou desnatado, produzido, beneficiado e envasado em estabelecimento denominado Granja Leiteira, observadas as prescrições contidas no Regulamento Técnico (BRASIL, 2002).

b) Leite Cru Refrigerado tipo B: produto definido no Regulamento Técnico (BRASIL, 2002), integral quanto ao teor de gordura, refrigerado em propriedade rural produtora de leite e nela mantido pelo período máximo de 48h (quarenta e oito horas), em temperatura igual ou inferior a $4^{\circ} \mathrm{C}$ (quatro graus Celsius), que deve ser atingida no máximo $3 \mathrm{~h}$ (três horas) após o término da ordenha, transportado para estabelecimento industrial, para ser processado, onde deve apresentar, no momento do seu recebimento, temperatura igual ou inferior a $7^{\circ} \mathrm{C}$ (sete graus Celsius).

c) Leite Cru tipo C: definido no Regulamento Técnico (BRASIL, 2002), como leite não submetido a qualquer tipo de tratamento térmico na fazenda leiteira onde foi produzido e integral quanto ao teor de gordura, transportado em vasilhame adequado e individual de capacidade até 50 I (cinquenta litros) e entregue em estabelecimento industrial adequado até às 10:00 h (dez horas) do dia de sua obtenção. O prazo de vigência do leite tipo $C$, cru ou pasteurizado foi até 01/07/2005 nas regiões Sul, Sudeste e Centro-Oeste e até 01/07/2007 nas regiões Norte e Nordeste.

d) Leite Cru Refrigerado: definido como produto refrigerado e mantido em temperatura máxima de conservação do leite: $7^{\circ} \mathrm{C}$ na propriedade rural/Tanque 
comunitário e $10^{\circ} \mathrm{C}$ no estabelecimento processador, transportado em carro-tanque isotérmico da propriedade rural para um Posto de Refrigeração de leite ou estabelecimento industrial adequado, para ser processado. Entretanto, admite-se o transporte de leite em latões e em temperatura ambiente, desde que o estabelecimento processador concorde em aceitar trabalhar com este tipo de matériaprima, que o leite seja entregue ao estabelecimento processador até no máximo 2 horas da conclusão da ordenha e que atinja os padrões de qualidade exigidos para o leite cru refrigerado.

Outro grande avanço nesta normativa foi o desenvolvimento da Rede Brasileira de Laboratórios de Controle da Qualidade do Leite (RBQL), a qual está credenciada ao MAPA e atende a mesma metodologia de referência em todos os laboratórios. A IN 51 exige que os estabelecimentos de captação de leite sejam responsáveis pela coleta de, no mínimo, uma amostra mensal por produtor para a realização de análises de composição, CCS e CBT, com limites estabelecidos conforme Tabelas 1 e 2.

Tabela 1- Requisitos microbiológicos, físicos, químicos, de CCS, de resíduos químicos do Leite Cru Refrigerado.

\begin{tabular}{|c|c|c|c|c|}
\hline $\begin{array}{ll}\text { Índice medido } & \text { por } \\
\text { propriedade rural ou por } \\
\text { tanque comunitário }\end{array}$ & $\begin{array}{lll}\text { Até } \quad 01 / 07 / 2005 & \text { Regiões } \\
\text { S/SE/CO } & \\
\text { Até } 01 / 07 / 2007 & \text { Regiões } \\
\text { N/NE } & & \end{array}$ & $\begin{array}{l}\text { De 01/07/2005 à 01/07/2008 } \\
\text { Regiões S/SE/CO } \\
\text { De 01/07/2017 à 01/07/2010 } \\
\text { Regiões N/NE }\end{array}$ & $\begin{array}{l}\text { De } 01 / 07 / 2008 \text { à } 01 / 07 / 2011 \\
\text { Regiões S/SE/CO } \\
\text { De 01/07/2010 à 01/07/2012 } \\
\text { Regiões N/NE }\end{array}$ & $\begin{array}{l}\text { A partir de 01/07/2011 } \\
\text { Regiões S/SE/CO } \\
\text { A partir de à } 01 / 07 / 2012 \\
\text { Regiões N/NE }\end{array}$ \\
\hline $\begin{array}{l}\text { Contagem Padrão em } \\
\text { Placas (CPP) expresso em } \\
\text { UFC/mL (mínimo de } 1 \\
\text { análise mensal com } \\
\text { geométrica sobre o período } \\
\text { de } 3 \text { meses). }\end{array}$ & $\begin{array}{l}\text { Máximo de } 1.000 .000 \text { para os } \\
\text { estabelecimentos que se } \\
\text { adequarem antecipadamente } \\
\text { aos termos do RTIQ. }\end{array}$ & $\begin{array}{l}\text { Máximo de } 1.000 .000 \text { para } \\
\text { todos os estabelecimentos } \\
\text { nos termos do RTIQ. }\end{array}$ & Máximo de 750.000 & $\begin{array}{l}\text { Máximo de } 100.000 \\
\text { (individual) } \\
\text { Máximo de } 300.000 \text { (leite de } \\
\text { Conjunto) }\end{array}$ \\
\hline $\begin{array}{l}\text { Contagem de Células } \\
\text { Somáticas (CCS) expresso } \\
\text { em Céls/mL (mínimo de } 1 \\
\text { análise mensal com } \\
\text { geométrica sobre o período } \\
\text { de } 3 \text { meses). }\end{array}$ & $\begin{array}{l}\text { Máximo de } 1.000 .000 \text { para os } \\
\text { estabelecimentos que se } \\
\text { adequarem antecipadamente } \\
\text { aos termos do RTIQ. }\end{array}$ & $\begin{array}{l}\text { Máximo de } 1.000 .000 \text { para } \\
\text { todos os estabelecimentos } \\
\text { nos termos do RTIQ. }\end{array}$ & Máximo de 750.000 & Máximo de 400.000 \\
\hline $\begin{array}{l}\text { Pesquisa de Resíduos de Ant } \\
\text { - MAPA }\end{array}$ & ióticos/Inibidores do crescim & to microbiano: Limites máxim & s Previstos no Programa Nacio & al de Controles de Resíduos \\
\hline
\end{tabular}

Fonte: INSTRUÇÃO NORMATIVA Nº 51 de 18 de setembro de 2002. Ministério de Agricultura,

Pecuária e Abastecimento. 
Tabela 2 - Requisitos Físicos e Químicos em Leite Cru Refrigerado a serem avaliados pela RBQL.

\begin{tabular}{|c|c|}
\hline Requisitos & Limites \\
\hline Matéria Gorda, $\mathrm{g} / 100 \mathrm{~g}$ & Teor original, com o mínimo de 3,0 \\
\hline Densidade relativa a $15 / 15^{\circ} \mathrm{C} \mathrm{g} / \mathrm{Ml}$ & 1,028 a 1,034 \\
\hline Acidez titulável, g ácido lático/100 MI & 0,14 a 0,18 \\
\hline Extrato seco desengordurado, $\mathrm{g} / 100 \mathrm{~g}$ & mín. 8,4 \\
\hline Índice Crioscópico máximo & $-0,530^{\circ} \mathrm{H}$ (equivalente $\mathrm{a}-0,512^{\circ} \mathrm{C}$ ) \\
\hline Proteínas, g /100g & mín. 2,9 \\
\hline \multicolumn{2}{|c|}{$\begin{array}{l}\text { Métodos Analíticos de Referência: Matéria Gorda, g/100 g (FIL } 1 \text { C: 1987); Extrato seco desengordurado, g/100 g (FIL } 21 \text { B: } \\
\text { 1987); Índice Crioscópico (FIL } 108 \text { A: 1969); Proteínas, g /100g (FIL } 20 \text { B:1993). }\end{array}$} \\
\hline
\end{tabular}

Fonte: INSTRUÇÃO NORMATIVA № 51 de 18 de setembro de 2002. Ministério de Agricultura, Pecuária e Abastecimento.

Além das análises mensais pela RBQL, o leite proveniente de um conjunto de produtores deve ser analisado no recebimento no Estabelecimento Beneficiador para cada compartimento do tanque, com as seguintes análises:

- Temperatura;

- Teste do Álcool /Alizarol na concentração mínima de 72\% v/v (setenta e dois por cento volume/volume);

- Acidez Titulável;

- IÍndice Crioscópico;

- Densidade Relativa, a $15 / 15^{\circ} \mathrm{C}$;

- Teor de Gordura;

- Pesquisa de Fosfatase Alcalina (quando a matéria-prima for proveniente de Usina e ou Fábrica);

- Pesquisa de Peroxidase (quando a matéria-prima for proveniente de Usina e ou Fábrica);

- $\quad \%$ de Extrato Seco Total e Desengordurado;

- Pesquisa de Neutralizantes da Acidez e de Reconstituintes da Densidade;

- $\quad$ outras pesquisas que se façam necessárias.

Em suma, a IN 51 foi um marco na evolução da qualidade do leite no Brasil, pois estabeleceu normas e limites nos parâmetros de qualidade e determinação dos tipos de leite. A RBQL foi desenvolvida para analisar as amostras de leite dos produtores e, assim, ter visibilidade geral quanto à qualidade do leite produzido no Brasil. A granelização da coleta do leite em tanque isotérmico foi um grande avanço 
na qualidade do leite recebido pelos laticínios, pois reduz a perda da qualidade no transporte, uma vez que conserva a temperatura do leite coletado na fazenda.

\subsubsection{A Instrução Normativa 62 (2011)}

Em 31 de dezembro de 2011 a IN 62 revogou o Anexo II e III da IN 51 (2002), os quais dizem respeito ao Regulamento Técnico de Produção, Identidade e Qualidade (RTIQ) do Leite B e C e Alterou os Anexos I, IV, V, e VI. Com isso, a IN 62 abrange a RTIQ do Leite A, Leite Pasteurizado e Leite Cru Refrigerado e seu Transporte a Granel.

O Leite Cru Refrigerado refere-se ao leite produzido nas propriedades rurais do território nacional e destinado à obtenção de Leite Pasteurizado para consumo humano direto ou para transformação em derivados lácteos em todos os estabelecimentos de laticínios submetidos à inspeção sanitária oficial.

Em 2011, a RBQL estimava que cerca de $40 \%$ do volume do leite não se adequava aos limites estabelecidos pela IN 51 (2002) para CBT e CCS. Com isso, a IN 62 (2011) estabeleceu um novo calendário de entrada em vigor de requisitos de qualidade, conforme descrito na Tabela 3.

Tabela 3 - Exigências na qualidade do Leite Cru Refrigerado.

\begin{tabular}{|c|c|c|c|c|}
\hline $\begin{array}{ll}\text { Índice medido } & \text { por } \\
\text { propriedade rural ou por } \\
\text { tanque comunitário }\end{array}$ & $\begin{array}{l}\text { De } 01 / 07 / 2008 \text { à } 31 / 12 / 2011 \\
\text { Regiões S/SE/CO } \\
\text { De } 01 / 07 / 2010 \text { à } 31 / 12 / 2012 \\
\text { Regiões N/NE }\end{array}$ & $\begin{array}{l}\text { De } 01 / 01 / 2012 \text { à } 30 / 06 / 2014 \\
\text { Regiões S/SE/CO } \\
\text { De } 01 / 01 / 2013 \text { à } 30 / 06 / 2015 \\
\text { Regiões N/NE }\end{array}$ & $\begin{array}{l}\text { De } 01 / 07 / 2014 \text { à } 30 / 06 / 2016 \\
\text { Regiões S/SE/CO } \\
\text { De } 01 / 07 / 2015 \text { à } 30 / 06 / 2017 \\
\text { Regiões N/NE }\end{array}$ & $\begin{array}{l}\text { A partir de } 01 / 07 / 2016 \\
\text { Regiões S/SE/CO } \\
\text { A partir de 01/07/2017 } \\
\text { Regiões N/NE }\end{array}$ \\
\hline $\begin{array}{l}\text { Contagem Padrão em } \\
\text { Placas (CPP) expresso em } \\
\text { UFC/mL (mínimo de } 1 \\
\text { análise mensal com } \\
\text { geométrica sobre o período } \\
\text { de } 3 \text { meses). }\end{array}$ & Máximo 750.000 & Máximo 600.000 & Máximo 300.000 & Máximo 100.000 \\
\hline $\begin{array}{l}\text { Contagem de Células } \\
\text { Somáticas (CCS) expresso } \\
\text { em Céls/mL (mínimo de } 1 \\
\text { análise mensal com } \\
\text { geométrica sobre o período } \\
\text { de } 3 \text { meses). }\end{array}$ & Máximo 750.000 & Máximo 600.000 & Máximo 500.000 & Máximo 400.000 \\
\hline $\begin{array}{l}\text { Pesquisa de Resíduos de An } \\
\text { - MAPA }\end{array}$ & oióticos/Inibidores do crescime & to microbiano: Limites máxim & s Previstos no Programa Naci & nal de Controles de Resíduos \\
\hline
\end{tabular}

Fonte: INSTRUÇÃO NORMATIVA No 62 de 29 de dezembro de 2011. Ministério de Agricultura, Pecuária e Abastecimento. 
Em 4 de maio de 2016 foi publicado no Diário Oficial da União alterando o prazo para adotar o limite de CBT 100.000 UFC/mL e CCS 400.000 céls/mL que iriam vigorar a partir de 01/07/2016 Regiões S/SE/CO e 01/07/2017 Regiões N/NE (Tabela 3), passam a vigorar somente a partir de 01/07/2018 Regiões S/SE/CO e 01/07/2019 Regiões N/NE (BRASIL, 2016).

A IN 62 também trouxe algumas exigências em termos de qualidade e sanidade na produção de leite, tais como:

- Critérios de sanidade do rebanho no Regulamento de Leite Cru Refrigerado, os quais os veterinários devem atestar que o rebanho esteja livre de doenças infectocontagiosas como Brucelose e Tuberculose;

- Controle de mastite e parasitoses;

- Pesquisa de agentes inibidores do crescimento microbiano nas análises de recepção da matéria-prima a fim de impedir o processamento de leite com antibiótico;

- Os caminhões de transporte de leite devem ser lavados externamente antes da descarga e internamente após cada descarga de leite;

- A empresa captadora de leite deve implantar um programa de educação continuada dos participantes que deve ter sua eficácia demonstrada pelos resultados de análises de qualidade dos seus fornecedores realizados pela Rede Brasileira de Laboratórios da Qualidade do Leite.

A Figura 3 ilustra a "Linha do Tempo" com os principais fatos que colaboraram para da construção da qualidade do leite no Brasil e o que ainda está por vir.

Figura 3 - "Linha do Tempo" da construção da qualidade do leite no Brasil

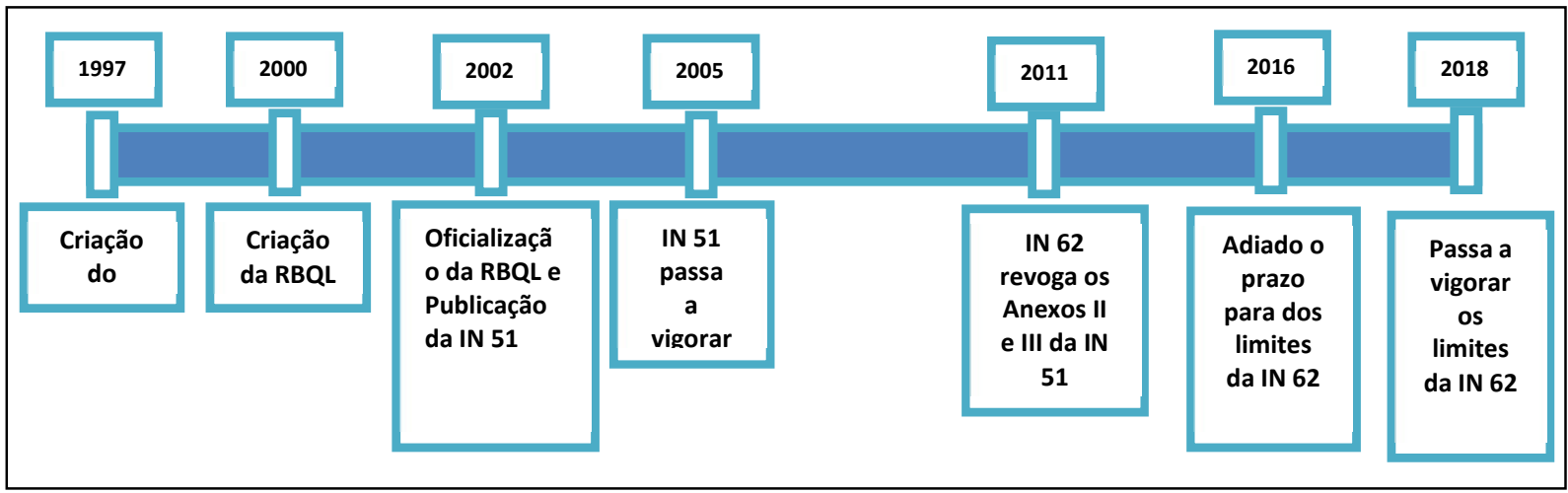

Fonte: Própria autoria 


\subsection{Gestão da Qualidade}

\subsubsection{A Importância da Gestão da Qualidade na Cadeia de Lácteos}

A qualidade de um produto acabado está diretamente relacionada com o nível de coordenação e estratégias focadas em qualidade aplicadas em toda a cadeia de produção. De acordo com Toledo et al. (2004), para promover a garantia e melhoria da qualidade ao longo de uma cadeia de produção agroalimentar é preciso estabelecer um enfoque coordenado (envolvendo produtores, processadores, governo, varejo, exportadores) orientando-se para o mercado, buscando satisfazer suas exigências.

A busca incessante na melhoria da qualidade do produto, tanto no que diz respeito à segurança do alimento, como no que diz respeito à satisfação do consumidor são fatores cruciais para a competitividade. Isso quer dizer que a atenção deve ser dada em todas as etapas da cadeia produtiva, ou seja, obtenção da matéria prima, processamento industrial, distribuição e comercialização (RAMOS et al., 2010). Portanto, a competitividade e sobrevivência dos laticínios brasileiros estão ligadas à gestão da qualidade (TOLEDO et al., 2004).

A coordenação deste tipo de programa de gestão da qualidade deve ser sinérgica, de modo que a capacitação e implantação de Boas Práticas de Manejo e Ordenha na propriedade leiteira devem estar vinculadas a um robusto sistema de gestão da qualidade desempenhado pelo laticínio, no qual engloba o sistema de pagamento pela qualidade do leite, planejamento de análises do leite captado em cada propriedade e assistência técnica ao produtor em caso de não atendimento das normas (SCALCO; TOLEDO, 2002).

Além disso, para que a empresa captadora de leite receba as cargas com qualidade na recepção do leite, é necessário ter gestão das rotas, respeitando os horários de coleta, taxa de ocupação máxima, controle de manutenção, checagens e limpeza do caminhão e do tanque de transporte de leite. Este fato é confirmado por Assumpção (2002), no qual defende que a cadeia de suprimento engloba, além das atividades envolvidas no processo de fabricação, as atividades relacionadas à logística entre as unidades produtivas.

Existem várias metodologias e ferramentas que auxiliam a gestão da qualidade nas organizações. Dentre estas, destacam-se: PDCA (Planejar, Executar, Verificar, Agir), Diagrama de Pareto, Curva ABC, Diagrama de Causa e Efeito, Plano de Ação 
e Análise (5Ws2Hs), Método de Análise e Solução de Problemas (MASP), as quais serão descritas nos tópicos a seguir (MARIANI, 2005).

\subsubsection{Ferramentas da Gestão da Qualidade}

\subsubsection{Ciclo PDCA}

O Ciclo PDCA, também é conhecido como Ciclo de Shewhart, Ciclo da Qualidade ou Ciclo de Deming. Trata-se de uma metodologia que tem como função básica o auxílio no diagnóstico, análise e prognóstico de problemas organizacionais, sendo extremamente útil para a solução de problemas (PACHECO et al., 2007).

A metodologia foi desenvolvida por Walter A. Shewhart na década de 30 e consagrada por Willian Edwards Deming na década de 50, onde foi empregada com sucesso nas empresas japonesas para a melhoria da qualidade dos processos (PACHECO et al., 2007).

Como a utilização do Ciclo PDCA está intimamente ligada ao entendimento do conceito de processo, é importante que todos os envolvidos em sua aplicação entendam a visão processual e estejam comprometidos com o trabalho de melhoria da qualidade (PACHECO et al., 2007).

O ciclo PDCA é um método gerencial para a promoção da melhoria contínua, através de suas quatro fases, praticadas de forma cíclica e ininterrupta, a fim de obter consolidação da padronização de práticas (MARSHALL JUNIOR et al., 2007).

Como pode ser observado na própria nomenclatura e também na Figura 4, o Ciclo PDCA está dividido em quatro fases bem definidas e distintas, conforme detalhado a seguir: 
Figura 4- Ciclo de Deming ou Ciclo PDCA.

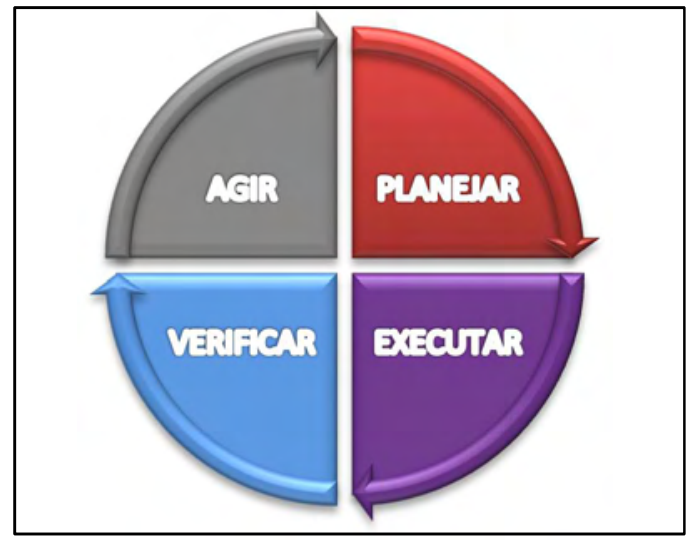

Fonte: MARSHALL JUNIOR, I. et al. Gestão da Qualidade. Rio de Janeiro. Ed FGV, 2007. 196p.

\section{1a Fase: $\mathbf{P}$ (Plan = Planejar)}

Segundo Pacheco et al. (2007), esta fase é caracterizada pelo estabelecimento de um plano de ações e está dividida em duas etapas:

a) a primeira consiste em definir o que se quer com a finalidade de planejar o que será feito. Esse planejamento envolve a definição de objetivos, estratégias e ações, os quais devem ser claramente quantificáveis (metas);

b) a segunda consiste em definir quais os métodos que serão utilizados para se atingir os objetivos traçados.

Aplicando esta fase do PDCA no cenário de uma indústria captadora e/ou processadora de leite com problemas na qualidade do leite, o primeiro passo é realizar um diagnóstico para entender qual é o trabalho desempenhado na gestão da qualidade do leite. Considerando os objetivo e metas de atender $100 \%$ as exigências da IN 62 nos limites de CBT e CCS, por exemplo, é possível definir a metodologia e ferramentas que deverão ser aplicadas no modelo de gestão da qualidade desta empresa, a fim de obter solução no problema de qualidade do leite.

\section{2a Fase: D (Do = Executar)}

De acordo com Pacheco et al. (2007), esta fase caracteriza-se pela execução do que foi planejado e, da mesma forma que a primeira fase, está dividida em duas etapas:

a) Capacitar a organização para que a implementação do que foi planejado possa ocorrer. Envolve, portanto, aprendizagem individual e organizacional;

b) Consiste em implementar o que foi planejado. 
Neste sentido, ao aplicar esta fase em um laticínio, os treinamentos devem ser colocados em prática para que sejam possíveis os andamentos das ações planejadas no início do Ciclo PDCA. Por exemplo, treinar os técnicos de campo para orientarem os produtores de leite a produzirem um leite com qualidade, capacitar um analista para que faça o controle adequado dos resultados das análises de qualidade do leite por meio da elaboração da Curva $\mathrm{ABC}$, documentar procedimentos e registros de ações, desenvolver check-list para verificações de possíveis desvios.

\section{$3^{\mathrm{a}}$ Fase: $\mathbf{C}($ Check $=$ Verificar $)$}

Esta fase consiste em verificar se o planejado foi consistentemente alcançado através da comparação entre as metas desejadas e os resultados alcançados. Para esta verificação devem ser utilizadas ferramentas de acompanhamento dos resultados e indicadores, ou seja, esta comparação deve ser baseada em fatos e dados e não em opiniões (MARSHALL JUNIOR et al., 2007).

Na prática do laticínio, esta verificação deve ser acompanhada por ferramentas de indicadores da qualidade, os quais acompanham os resultados e relacionam com o volume de cada fazenda, caminhão e silo de armazenamento. Deste modo, podese acompanhar a evolução ou não dos resultados diante das ações estabelecidas no planejamento do ciclo PDCA.

\section{$4^{\text {a }}$ Fase: $\mathrm{A}$ (Action = Agir corretivamente)}

Nesta fase têm-se duas alternativas. No caso de não terem sido alcançadas as metas planejadas buscam-se as causas fundamentais a fim de prevenir a repetição de efeitos indesejados ou, no caso das metas planejadas serem alcançadas, adotase como padrão o planejado na primeira fase (MARSHALL JUNIOR et al., 2007).

Segundo Marshall Junior et al. (2007), girar o PDCA significa obter previsibilidade nos processos e aumento da competitividade organizacional. A previsibilidade acontece pela obediência dos padrões, pois quando a melhoria é bemsucedida adota-se o método planejado, padronizando-o.

Na prática do laticínio verifica-se o cumprimento das metas e caso haja desvios, deve haver uma investigação a fim de determinar a causa raiz e implementar ações corretivas, por exemplo, capacitação de grupos de produtores através de ensinamentos práticos. Essas ações corretivas devem ser feitas até que se atinja um padrão de procedimentos e não haja interferência na qualidade. 
$\mathrm{Na}$ utilização do método PDCA muitas ferramentas de melhoria contínua podem ser utilizadas para possibilitar o desenvolvimento das etapas que envolvem o ciclo.

\subsubsection{Diagrama de Pareto}

O Diagrama de Pareto foi desenvolvido por Joseph Juran a partir de análises e estudos realizados pelo economista italiano Wilfried Fritz Pareto e pelo americano Max Otto Lorens. Tem como objetivo o estabelecimento de prioridades, ou seja, mostra a ordem em que os problemas acontecem e devem ser resolvidos (SELEME; STANDLER, 2010).

Conforme o exposto na Figura 5, os dados relacionados a todos os problemas que ocorrem em um processo, são organizados em ordem decrescente, de acordo com o giro de ocorrências ou a gravidade de cada problema, é possível avaliar no gráfico quais são os problemas mais graves e que precisam ser tratados com mais urgência.

Figura 5-Diagrama de Pareto

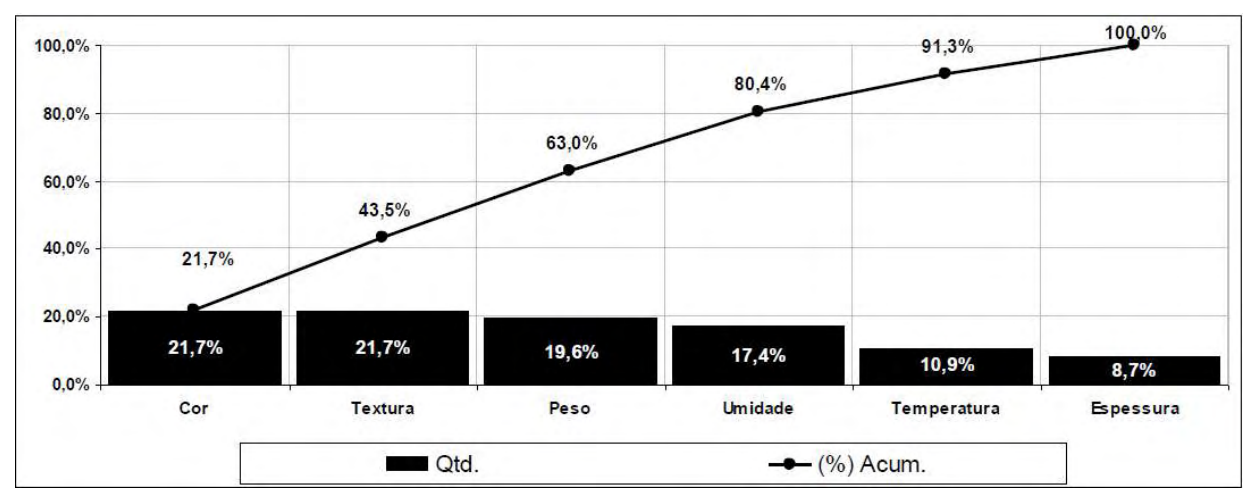

Fonte: SIMÕES, L.; RIBEIRO, C. M. O Ciclo PDCA como ferramenta da Qualidade Total. In: Encontro Cientifico Unisalesiano. 2009.

Normalmente se planejam as ações de melhoria para os itens que fazem parte do percentual acumulado de cerca de $80 \%$ dos problemas indicados no gráfico, já que estes representam os itens de maior impacto.

Na prática, o Diagrama de Pareto é muito utilizado para definir a prioridade que o técnico de campo deve agir nos trabalhos focados em melhoria da qualidade. Por exemplo, uma relação de produtores com resultado ruim da qualidade é relacionada 
com os volumes de leite diário, deste modo é possível determinar a representatividade do volume de cada produtor. Através desse raciocínio, uma simulação foi desenhada conforme a Figura 6, no qual apresenta a prioridade das ações no campo, de modo que a sequência dos produtores $\mathrm{B}, \mathrm{C}, \mathrm{H}, \mathrm{D}$ e $\mathrm{G}$ representam mais de $80 \%$ dos problemas, ou seja, estes devem ser visitados e orientados pelo técnico de campo primeiro.

Figura 6-Diagrama de Pareto aplicado no controle da qualidade do leite

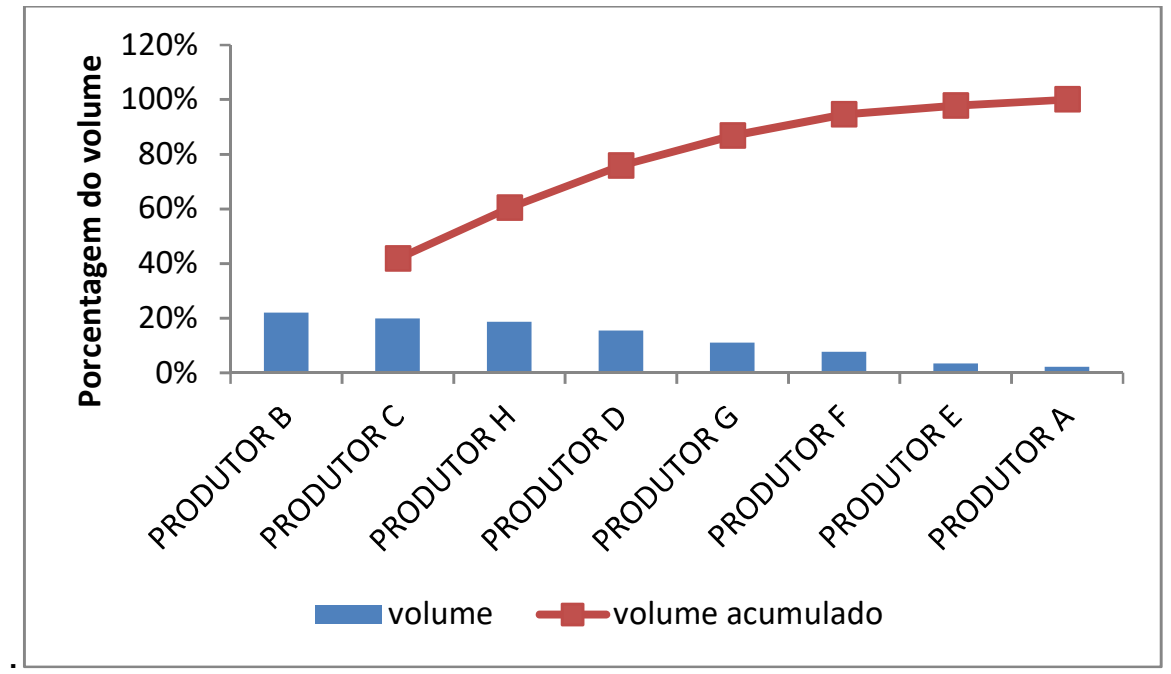

Fonte: Própria autoria.

\subsubsection{Curva $A B C$}

A Curva $A B C$ foi fundamentada com base no teorema do economista Wilfried Fritz Pareto, da Itália, no século XIX, que realizou um estudo sobre a distribuição de renda das populações, no qual observou que uma pequena parcela da população concentrava a maior parte da riqueza, restando uma pequena percentagem de renda para uma grande parcela da população (GONÇALVES, 2010).

No início da década de 1950 foi colocado em prática por engenheiros da General Eletric, nos Estados Unidos, os quais começaram a estudar esse efeito da distribuição de renda na administração de materiais utilizados na organização (GONÇALVES, 2010). Com isso, a Curva $A B C$ tem sido uma ferramenta útil e de fácil aplicação nos princípios de controle de estoque (POZO, 2002).

O principal objetivo da Curva ABC, segundo Gonçalves (2010):

Identificar os itens de maior valor de demanda e sobre eles exercer uma gestão mais refinada, especialmente porque representam altos 
valores de investimentos e seu controle mais apurado vai permitir grandes reduções nos custos dos estoques.

Deste modo, a Figura 7 representa um exemplo de Curva $A B C$ que relaciona a porcentagem do volume de produção de leite pela porcentagem de produtores. A Classe A representa $20 \%$ dos produtores que produzem $50 \%$ do volume de leite. A Classe B representa $30 \%$ dos produtores que produzem $30 \%$ do volume de leite. A Classe $C$ representa $50 \%$ dos produtores que produzem apenas $20 \%$ do volume.

Figura 7 - Curva ABC.

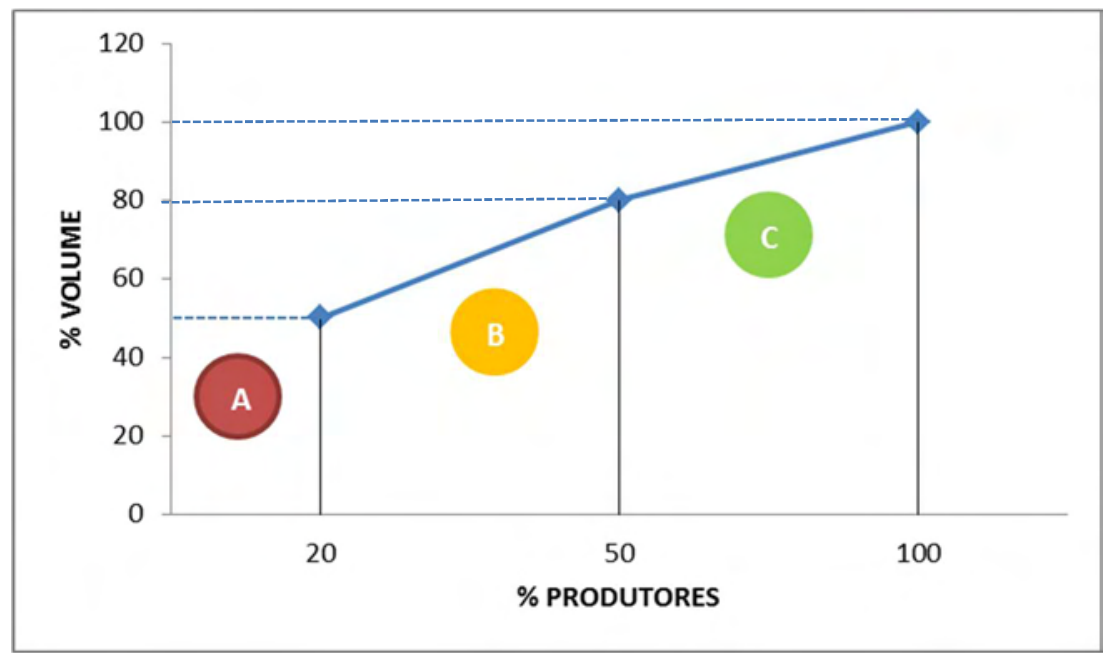

Fonte: Própria autoria.

Com isso, o refinamento da gestão aponta a Classe A como detentora de maior volume e menor número de produtores e por este motivo, deve ser trabalhada com prioridade para obtenção de maior resposta. Em seguida a gestão de prioridade segue para os produtores da Classe B e por último a Classe C.

\subsubsection{Diagrama de Causa e Efeito}

O diagrama de causa e efeito, também conhecido como diagrama de Ishikawa ou diagrama espinha de peixe, é definido por Marshall Junior et al. (2007) como uma ferramenta de representação das possíveis causas que levam a um determinado efeito. 
As causas são agrupadas por categoria e semelhanças previamente estabelecidas, ou percebidas durante o processo de classificação. Com isso, a primeira etapa de elaboração do diagrama de causa e efeito é a discussão do assunto a ser analisado pelo grupo, contemplando seu processo, como e onde ocorre, áreas envolvidas e escopo (MARSHALL JUNIOR et al. 2007).

De acordo com Carpinetti (2010), a participação do maior número possível de pessoas envolvidas com o processo é muito importante para que se possa construir um diagrama completo. Na execução deste levantamento em equipe é aconselhado que sejam realizadas sessões de brainstorming, pois essa ferramenta tem o objetivo de auxiliar um grupo de pessoas a produzir o máximo possível de idéias em um curto período de tempo.

Uma vez definido o problema a ser analisado, a equipe deve se concentrar na identificação de todas as possíveis causas. Nesta fase, a equipe deve repetidamente formular e responder a pergunta: Que tipo de variabilidade (nas causas) poderia afetar a característica da qualidade de interesse ou resultar no problema considerado. Em seguida, para cada causa deve-se fazer a seguinte pergunta: Por que isso acontece? A resposta a essa pergunta levará a possíveis causas que se ramificam a partir da causa anterior com o objetivo às causas fundamentais da ocorrência de problemas (CARPINETTI, 2010).

Na construção do diagrama referido, o efeito (problema ou condição específica) está descrito no lado direito do diagrama (Figura 8) e o levantamento das possíveis causas, descrito conforme a classificação:

a) Método: relacionado à forma que o processo é realizado;

b) Matéria prima: relacionado aos insumos necessários para a realização do processo;

c) Mão-de-obra: relacionado à mão-de-obra utilizada para realizar o trabalho;

d) Máquina: relacionado a todos os equipamentos utilizados no processo;

e) Meio-ambiente: relacionada ao ambiente de trabalho como iluminação, temperatura, ruídos, etc;

f) Medida: relacionado à forma como se mede o desempenho do processo ou a forma como é controlado.

É importante citar que cada causa relacionada no diagrama e seu respectivo efeito devem ser estabelecidos não somente com base na experiência, mas sim como dados mensuráveis (CARPINETTI, 2010). 
Figura 8-Diagrama de Ishikawa ou Espinha-de-peixe.

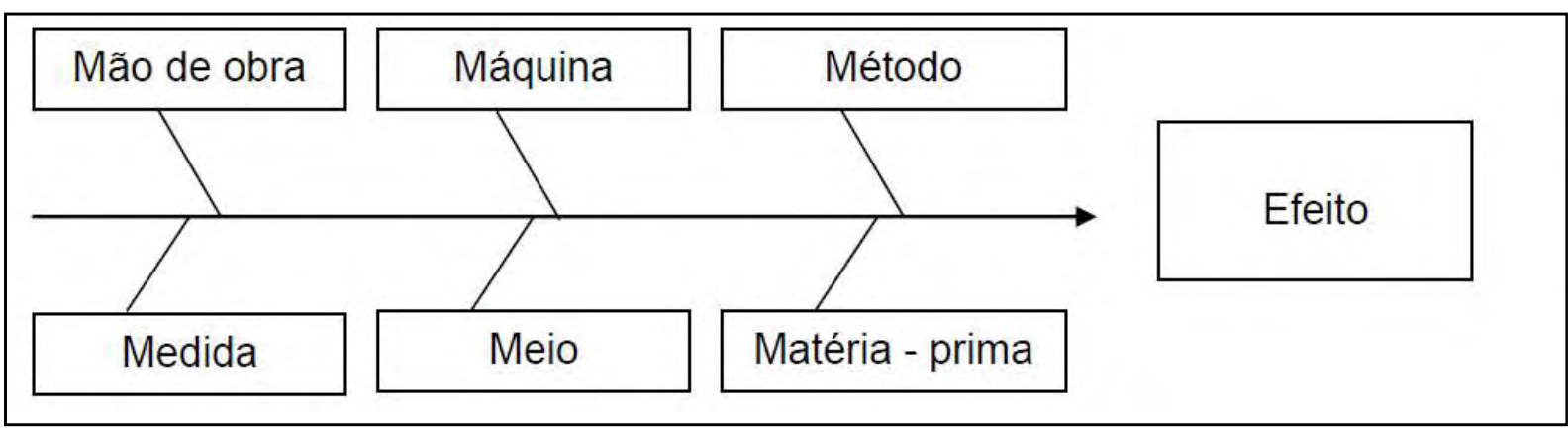

Fonte: SIMÕES, L.; RIBEIRO, C. M. O Ciclo PDCA como ferramenta da Qualidade Total. In: Encontro Cientifico Unisalesiano. 2009.

Ao desenvolver o diagrama de causa e efeito diante do problema de Contagem Bacteriana Total no leite na fazenda maior que $300.000 \mathrm{UFC} / \mathrm{mL}$, são identificadas as possíveis causas dos fatores de risco da proliferação bacteriana:

a) Método: Procedimento de ordenha e limpeza dos equipamentos, ou seja, a causa a ser apontada é a falta de cumprimento ou desconhecimento dos mesmos;

b) Máquina: Manutenção planejada dos equipamentos de ordenha, deste modo, a causa pode ser a falta de atendimento da manutenção programada;

c) Mão de obra: Treinamento de funcionários quanto aos procedimentos e técnicas, sendo a falta de treinamento uma causa;

d) Medida: Controle dos resultados mensais do tanque e desenvolvimento de indicador CBT. Se não houver acompanhamento ou amostras mensais, o produtor não identifica a CBT alta e não tem ação diante da procura de causas;

e) Ambiente: Sala de ordenha, sala de espera, cama dos animais, sala do tanque de refrigeração do leite, entre outros. Todos os ambientes devem ser limpos frequentemente, conforme procedimentos estabelecidos. A falta desta prática pode ser uma causa do problema estudado.

Conforme o diagrama construído na Figura 9, observam-se as possíveis falhas no processo de manejo de ordenha que podem trazer efeitos negativos na qualidade do leite. 
Figura 9-Diagrama de Causa e Efeito no estudo de caso de fatores de risco da CBT alta.

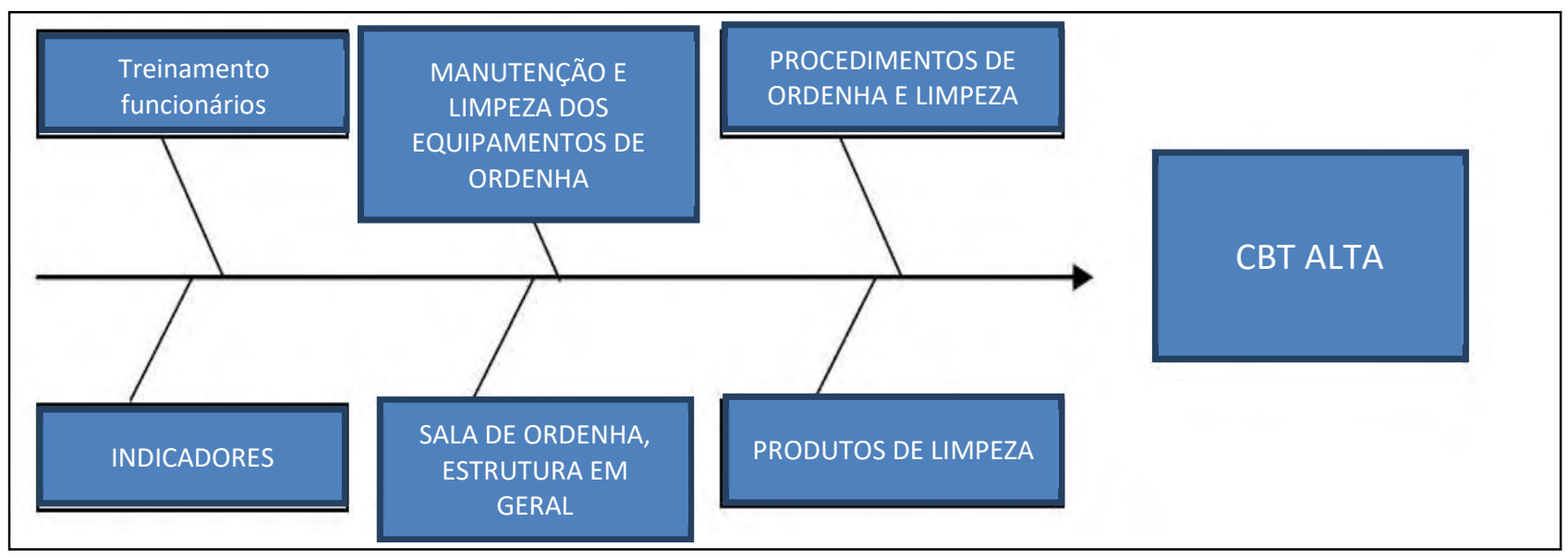

Fonte: Própria autoria.

\subsubsection{Planos de ação e análise: $5 W s$ e 2 Hs.}

A ferramenta 5W2H ou Plano de Ação é utilizada para descrever os problemas existentes, e assim obter um planejamento específico gerando ações corretivas efetivas (MARTINS, 2013).

Segundo Marshall Junior et al. (2007), o 5W2H é de cunho basicamente gerencial e busca fácil entendimento através da definição de responsabilidades, métodos, prazos, objetivos e recursos associados.

$\mathrm{O} 5 \mathrm{~W} 2 \mathrm{H}$ representa as iniciais das palavras, em inglês, why (por que), what (o que), where (onde), when (quando), Who (quem), how (como) e how much (quanto custa).

A Tabela 4 representa um exemplo prático de um desenvolvimento de um Plano de Ação com todos os detalhes do $5 \mathrm{~W} 2 \mathrm{H}$. Neste caso o objetivo é restabelecer os resultados de fazendas de um laticínio que estão fora do padrão em CBT, com um plano de ação direcionado e detalhado com prazo estabelecido. É importante realizar o planejamento junto aos envolvidos nas ações, para que sejam esclarecidas todas as dúvidas e haja consentimento da data estabelecida pelo prazo de execução das ações. Além disso, o líder o qual formulou o plano deve acompanhar criteriosamente a realização das ações dentro das exigências e do prazo. 
Tabela 4 - Plano de Ação com objetivo de Redução na CBT (contagem Bacteriana total) do leite de produtores.

\begin{tabular}{|c|c|c|c|c|c|}
\hline \multicolumn{6}{|c|}{ Plano de Ação } \\
\hline Setor: & Compra de leite in natura & & & & \\
\hline Objetivo: & Redução da CBT (contagen & m Bacteriana Total) & & & \\
\hline O QUE & QUEM QUANDO & ONDE & POR QUE & COMO & CUSTOS \\
\hline Realizar Visita em & & Fazenda & $\begin{array}{l}\mathrm{CBT}> \\
300.000\end{array}$ & $\begin{array}{l}\text { Utilizar a } \\
\text { ferramenta Check }\end{array}$ & \\
\hline Produtores & Técnico 1 até 15/03/2014 & fornecedora de leite & $\mathrm{UFC} / \mathrm{mL}$ & List-CBT & $R \$ 60,00$ \\
\hline $\begin{array}{l}\text { Coletar amostra de } \\
\text { leite e enviar ao }\end{array}$ & & Fazenda & $\begin{array}{l}\text { Avaliar } \\
\text { visita do }\end{array}$ & $\begin{array}{l}\text { Procedimento de } \\
\text { coleta de amostra }\end{array}$ & \\
\hline laboratório. & Técnico 2 até 16/03/2014 & fornecedora de leite & Técnico 1 & de leite, & $\mathrm{R} \$ 70,00$ \\
\hline
\end{tabular}

Fonte: Própria autoria.

\subsubsection{Método de Análise e Solução de Problemas (MASP)}

A solução dos problemas da empresa deve ser feita de forma metódica e com a participação de todos, ou seja, do presidente ao operador. Este é o princípio do "Gerenciamento Participativo" (CAMPOS, 1999).

Problema é o efeito indesejado de um processo, ou seja, é um resultado no qual não se está satisfeito ou uma meta não alcançada. É importante separar o efeito de causa, pois, para um mesmo problema (efeito), pode-se ter uma série de causas, que uma vez eliminadas ou controladas farão com que o problema seja solucionado ou fique sob controle (MARSHALL JUNIOR et al., 2007)

O Método de Análise e Soluções de Problemas (MASP) é uma ferramenta que trás maior detalhamento ao método PDCA, permitindo a realização do controle de qualidade em toda empresa (CARPINETTI, 2010; MARSHALL JUNIOR et al. 2007).

Os passos a seguir representam uma sugestão de desdobramento do ciclo PDCA segundo Marshall Junior et al. (2007):

10 Passo - Identificação do Problema:

- Selecionar o problema a solucionar;

- Nomear os responsáveis e a equipe, propondo data limite para a sua conclusão;

\section{$2^{\circ}$ Passo - Observação}

- Entender o problema, levantando seu histórico e frequência de ocorrência;

- Observar as características no local, como ambiente, instrumentos, confiabilidade dos padrões, treinamento, entre outras; 
$3^{\circ}$ Passo - Análise

- Identificar as causas mais prováveis do problema;

$4^{\circ}$ Passo - Plano de Ação

- Elaborar a estratégia e o plano;

$5^{\circ}$ Passo - Ação

- Divulgar o plano de ação;

- Treinar e capacitar pessoas, buscando o comprometimento de todos;

- Executar e acompanhar a ação, registrando os resultados;

- Coleta de dados e registros;

$6^{\circ}$ Passo - Verificação

- Comparar os resultados com as metas esperadas;

- Verificar a continuidade ou não do problema. Se os resultados esperados não foram alcançados, volte ao $2^{\circ}$ Passo;

- Listar eventos secundários;

$7^{\circ}$ Passo - Padronização

- Elaborar ou alterar o padrão;

- Comunicar internamente as alterações;

- Treinar todos os envolvidos no novo padrão;

$8^{\circ}$ Passo - Conclusão

- Registrar os avanços obtidos pelo grupo;

- Relacionar os problemas remanescentes;

- Planejar a solução dos problemas remanescentes, voltando a executar o PDCA;

- Refletir sobre o trabalho visando uma melhoria continua.

Exemplificando o MASP, a Clínica do Leite desempenha um trabalho de Método e Análise de Soluções de Problemas de Mastite em Rebanhos Leiteiros. Esta metodologia é aplicada através do tripé "Liderança - Método - Técnica", ou seja, a liderança engaja a equipe a se comprometer com os resultados através dos métodos estabelecidos e da técnica engajada (MACHADO, 2014).

A ordem é caracterizada pela metodologia OPA (Olhe - Pense - Aja): 
- A fase "Olhe" deve haver um diagnóstico da propriedade de leite constando os históricos de resultado da qualidade, ambiente, mão de obra, ordenha e procedência dos animais.

- A fase "Pense": Analisar a causa dos problemas através do diagrama de causa e efeito, definição das metas e elaboração do plano de ação.

- A fase "Aja": treinar as pessoas, acompanhar as rotinas, verificar o atingimento de metas e dar feed-back.

\subsection{Qualidade na cadeia produtiva do leite}

De acordo com Brito (2008), o esforço de produzir alimentos seguros é responsabilidade de todos os segmentos da cadeia de alimentos, isto é, envolve diferentes elos produtivos, desde a produção primária até o consumo.

Medidas de controle devem prevenir a proliferação bacteriana, a presença de resíduos químicos de antibióticos, pesticidas, metais pesados e micotoxinas resultantes de tratamento ou da ingestão de alimentos contaminados, bem como a prevenção de quaisquer contaminantes físicos (corpos estranhos) (BRITO, 2008).

Os instrumentos legais e as orientações para a produção de alimentos seguros geralmente definidos como "Códigos de Práticas Higiênicas" tais como as Boas Práticas Agropecuárias (BPA), Boas Práticas de fabricação (BPF), e o sistema APPCC (Análise de Perigos e Ponto Crítico de Controle), têm demonstrado sua efetividade especialmente nos segmentos de manufatura e distribuição de alimentos (BRITO, 2008).

A seguir estão descritos os principais procedimentos a serem seguidos para se obter produção segura em toda cadeia de produção de leite.

\subsubsection{A qualidade do leite na fazenda}

A produção de leite deve ser aprimorada de forma a se obter a garantia de um leite seguro e com qualidade. Diante desta demanda, as Boas Práticas Agropecuárias (BPA) na produção de leite englobam as áreas de saúde animal, higiene na ordenha, alimentação, bem-estar-animal e ambiente, constituindo-se no suporte adequado para uma produção eficiente e segura, conforme ilustra a Figura 10. 
Figura 10- Principais componentes e objetivos da boas práticas de produção de leite.

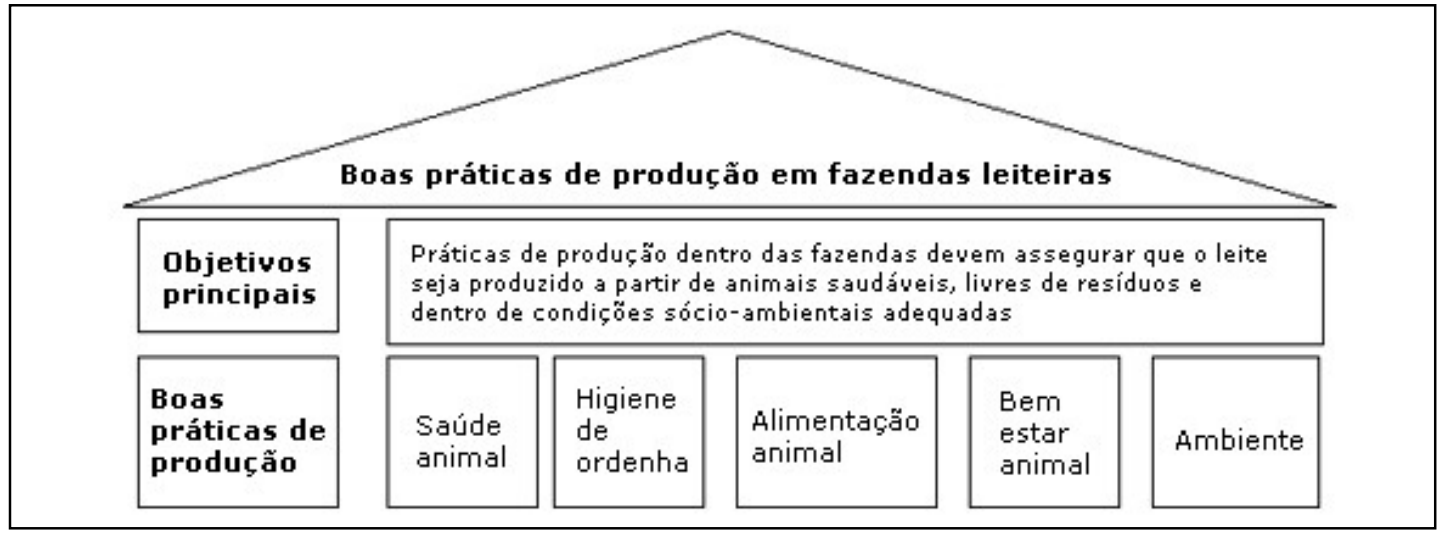

Fonte: SANTOS, M. V. Boas práticas de produção associadas à higiene de ordenha e qualidade do leite. In: O Brasil e a nova era do mercado do leite - Compreender para competir. Piracicaba-SP : Agripoint Ltda, 2007, v.1, p. 135-154.

De acordo com Santos (2007), as potenciais vantagens para os produtores que implantam esses programas são o aumento da competitividade, o oferecimento de produtos diferenciados e a maior garantia de permanência dos mercados. Para os consumidores, a principal vantagem é a garantia de alimentos seguros e de alta qualidade.

\subsubsection{A sanidade dos animais}

Os requisitos a seguir são baseados no programa de Boas Práticas Agropecuárias segundo Brito et al. (2008). A sanidade dos animais é primordial para a produção de um leite seguro, livre de patógenos e doenças. Deste modo, o produtor deve prevenir a entrada de doenças no rebanho, através das seguintes medidas:

- Compra ou entrada de animais com Boletim Sanitário conhecido;

- Programa de controle de pragas;

- Adotar um programa para a saúde do rebanho, que consista em:

a. Uma efetiva identificação dos animais;

b. Vacinações conforme orientação do Ministério da Agricultura, Pecuária e Abastecimento;

c. Controle de ectoparasitas e endoparasitas;

d. Registros de todos os tratamentos com identificação apropriada dos animais medicados; 
e. A utilização dos medicamentos deve ser orientada por um médico veterinário;

f. Guardar os medicamentos em local seco e seguro, preferencialmente com acesso restrito apenas ao responsável pelos tratamentos;

g. Além disso, os medicamentos indicados para uso em vacas em lactação devem ser separados dos medicamentos para vacas secas e animais não lactantes;

h. Isolamento dos animais doentes e separação do leite dos animais doentes e em tratamento, ou seja, o lote dos animais doentes e em tratamento deve ser ordenhado por último em uma unidade separada, além disso, o leite desses animais deve ser descartado, respeitando o período de carência do medicamento;

i. Deve haver adoção de medidas específicas relativas às doenças que afetam a saúde pública (zoonoses).

Os trabalhadores envolvidos na rotina da fazenda devem ser capacitados quanto aos registros e procedimentos a serem realizados.

\subsubsection{Cuidados no manejo e higiene da ordenha}

A ordenha é uma das tarefas mais importantes dentro de uma fazenda leiteira. A produção de leite de alta qualidade implica na necessidade de um manejo de ordenha que reduza a contaminação biológica, química e física do leite (SANTOS, 2007). Deste modo, o leite deve ser obtido e armazenado de forma higiênica e os equipamentos usados para ordenhar e armazenar o leite devem ser apropriados e mantidos de maneira correta e regular (BRITO et al., 2008).

Para que isto aconteça, deve-se garantir que os ordenhadores tenham hábitos apropriados de higiene, estejam livres de doenças infecto contagiosas e que recebam treinamentos de Boas Práticas na Ordenha. Além disso, as instalações da sala de ordenha devem ser mantidas limpas, tendo boa ventilação iluminação e drenagem, não deixando acumular fezes dos animais durante este processo. Deve haver fácil acesso de lavabos para a sanitização frequente das mãos dos ordenhadores. A utilização de luvas descartáveis pelos ordenhadores é recomendado, entretanto, deve haver a troca das luvas a cada lote de vacas ou quando as mesmas estiverem sujas.

A condução dos animais para a sala de ordenha deve ser realizada de maneira racional e sem estresse, pois agressões e gritos dos condutores de animais provocam 
nos animais a liberação do hormônio adrenalina que é antagônico à ocitocina. A ocitocina é o hormônio que promove a liberação do leite, atuando na contração de células que envolvem os alvéolos das glândulas mamárias (ZAFALON, 2008).

Antes do início da ordenha deve ser feito o teste da caneca de fundo preto ou telada, a fim de identificar novos casos de mastite clínica com o aparecimento de grumos no leite.

A identificação da mastite subclínica deve ser realizada através do "California Mastitis Test" (CMT) realizado na própria fazenda ou análise de Contagem de Células Somáticas (CCS) individuais dos animais realizada em laboratório externo, mensalmente. O resultado do CMT é classificado como negativo (sem viscosidade), suspeito (levemente viscoso), fracamente positivo (viscosidade moderada) e fortemente positivo (viscosidade intensa). Animais com CCS até 200.000 céls $/ \mathrm{mL}$ são saudáveis acima disso, são casos novos ou crônicos, de acordo com o histórico do animal (SANTOS; FONSECA, 2007).

Os animais devem ser ordenhados em linha de ordenha, de modo que as vacas com mastite clínica, subclínica fiquem em lote separado e sejam ordenhadas por último, a fim de evitar contaminação dos lotes sadios.

A utilização de água no úbere e tetos deve ser evitada, entretanto, caso esteja repleto de barro e sujidades, lava-se somente a região do teto e seca-se com papel toalha descartável, a fim de evitar que o resíduo dessa água escorra para o leite no momento da ordenha, contaminando-o.

O pré-dipping é um procedimento de desinfecção dos tetos e tem como objetivo a prevenção de mastite ambiental e a redução da contaminação bacteriana no leite. Este consiste na imersão dos tetos em solução desinfetante, podendo ser utilizada solução de iodo $(0,25 \%)$, clorexidine (de $0,25 \%$ a $0,5 \%$ ) ou ainda cloro $(0,2 \%)$. O ideal é a utilização do copo aplicador sem retorno para que a solução em contato com o teto não misture com a solução restante. A solução deve agir por 30 segundos e depois disso, seca-se os tetos com papel toalha descartável (ROSA, et al. 2009).

Em ordenha mecânica, a colocação das teteiras é considerada o momento crucial da ordenha, pois caso não seja bem feita, pode comprometer todas as etapas posteriores, inclusive, a qualidade do leite. O tempo de duração da ocitocina na corrente sanguínea é de no máximo 8 minutos. Por este motivo, o tempo recomendado entre a estimulação dos tetos até a colocação das unidades de ordenha seja de aproximadamente um minuto (ZAFALON, 2008). 
O registro de vácuo deve ser aberto apenas imediatamente antes da colocação das teteiras no animal, para evitar a entrada de ar no sistema de ordenha e a consequente flutuação do nível de vácuo, podendo ocorrer o gradiente de pressão reversa. Este gradiente faz com que o leite que está no copo coletor retorne ao canal do teto e à glândula mamária, possibilitando a contaminação bacteriana e a mastite. Durante a ordenha deve-se evitar o deslizamento das teteiras, o qual também possibilita a ocorrência do gradiente de pressão reversa. (ZAFALON, 2008).

No momento da retirada das teteiras, o registro de vácuo deve ser desligado para que não haja danos nos tetos dos animais. O conjunto de teteiras e o copo coletor não devem ser forçados para baixo com o vácuo ligado.

Após o término da ordenha, deve ser aplicada a solução pós-dipping, com intuito de proteger o esfíncter do teto que está dilatado, contra a entrada de microrganismos contagiosos e infecção das glândulas mamárias, sendo geralmente utilizada solução de iodo (0,5\%), de clorexidine (de 0,5 a 1,0\%) ou de cloro (de 0,3 a $0,5 \%$ ) (ROSA, et al. 2009). Além disso, após a ordenha deve ser oferecido alimento para os animais, diminuindo a probabilidade das vacas se deitarem. É fundamental, que ela permaneça em pé, pelo menos 30 minutos, para que o esfíncter se feche, diminuindo o risco de mastite ambiental.

\subsubsection{Manutenção preventiva da ordenha mecânica}

A manutenção preventiva dos equipamentos da ordenha mecânica é essencial para evitar injurias nos animais e contaminação do leite. Com isso, deve haver um cronograma de reparo a fim de garantir a reposição de peças, juntas, borrachas e calibração e aferição de termômetros, de acordo com a informação do fabricante. Além disso, a checagem do equipamento é fundamental para garantir o seu bom funcionamento e durabilidade (CBQL, 2002).

Durante a ordenha, o nível de vácuo do sistema deve ser aferido, para certificar que está dentro do limite, de acordo com o tipo de equipamento de ordenha, ou seja, Balde ao pé: $50 \mathrm{kPa}$; Canalizada Linha Alta: 48 a $50 \mathrm{kPa}$; Canalizada Linha Intermediária: 45 a 47 kPa; Canalizada Linha Baixa: 42 a 44 kPa (EMBRAPA, 2016).

Níveis abaixo do recomendado fazem com que haja deslizamento das teteiras, maior tempo de ordenha e a retirada do leite pode ser incompleta e irregular, podendo 
causar redução da produção, lesões nos tetos e esvaziamento incompleto do úbere, consequentemente a mastite (ZAFALON, 2008).

Diante disso, o fabricante Unsinox (2016) recomenda:

Se a pressão do vácuo estiver abaixo do recomendado, é provável que haja alguma entrada de ar no sistema. Portanto deve-se verificar se as tampas do interceptor estão corretamente posicionadas, na linha de vácuo verificar se há entrada de ar em conexões, tomadas de vácuo, válvulas do coletor e tampa(s) do latão (ões). Verificar se os pulsadores estão com frequência de 60 batidas por minuto.

De acordo com instruções do fabricante de ordenhadeira USINOX (2016), se a pressão do vácuo estiver acima do recomendado, é provável que o regulador de vácuo não esteja funcionando, normalmente por sujeira no filtro.

O nível de vácuo excessivamente alto e falhas no sistema de pulsação da ordenha levam a lesões atingindo a camada de queratina que compõe a face interna dos tetos e consequente formação de hiperqueratose (ZAFALON, 2008; EMBRAPA; 2016). Este fator faz com que haja maior acúmulo de bactérias na extremidade do teto, dificultando a sanitização e, como consequência, maiores ocorrências de mastite (ARAÚJO, 2012). Outro fator que leva a hiperqueratose nos tetos é a sobreordenha, ou seja, a continuação da ordenha mesmo após o término do fluxo de leite.

O principal componente para que a ordenhadeira massageie os tetos na frequência adequada por minuto é o pulsador. Este é uma válvula simples que alterna ar e vácuo na câmara de pulsação da teteira (LORENO, et. al. 2013). A relação de pulsação é o tempo da fase de ordenha e de massagem durante um ciclo de pulsação. Deste modo, uma relação de pulsação $60: 40$ representa $60 \%$ do tempo em ordenha e $40 \%$ em massagem. A fase de massagem é a que evita que o teto sofra danos; por isso, o risco de ordenhar mais rápido (aumentar a fase de ordenha) e diminuir a fase de massagem pode prejudicar o teto (EMBRAPA; 2016).

A troca das teteiras deve ser feita a cada 2.500 ordenhas se for de material sintético e a cada 5.000 a 7.500 ordenhas se for de silicone, ou a cada seis meses (EMBRAPA, 2016). Quando as borrachas dos insufladores ultrapassam o período de troca, elas apresentam rachaduras e tendem a absorver a gordura do leite, retendo bactérias e prejudicando a massagem dos tetos (ZAFALON, 2008). Além disso, pode ocorrer a subida da teteira obstruindo a prega anular do teto, tornando impossível a descida do leite (USINOX, 2016).

Segundo o CBQL (2002), o calculo do período de trocas $=2500$ / ( $\mathrm{a} \times \mathrm{b} / \mathrm{c}$ ), 
onde:

$\mathrm{a}=$ número de vacas ordenhadas por dia

$\mathrm{b}=$ número de ordenhas por dia

c = número de unidades de ordenha do equipamento

As mangueiras em contato com o leite devem ser trocadas a cada seis meses e as mangueiras de vácuo a cada um ano. Além disso, o nível do óleo do motor deve ser aferido ao ligar a ordenhadeira (CBQL; 2002).

\subsubsection{A Qualidade da água}

A qualidade da água utilizada na limpeza dos utensílios e máquinas de ordenha é extremamente importante, pois se estiver contaminada com coliformes, estes proliferam na superfície desses equipamentos, prejudicando a qualidade do leite. Portanto, o produtor deve conhecer a qualidade da água, quando armazenada em reservatório realizar a limpeza semestralmente e manter fechado e em boas condições para evitar o acesso de animais e possíveis contaminações (EMBRAPA, 2005).

No caso de poços e nascentes, os mesmos devem ser cercados e mantidos limpos ao seu redor. Os poços devem ficar tampados e ter uma pequena calçada de cimento com valetas ao entorno, para evitar a contaminação pelas chuvas e enxurradas (EMBRAPA, 2005).

Águas de açudes ou córregos são impróprias para a limpeza de equipamentos e utensílios e para a higiene pessoal, a menos que sejam tratadas (EMBRAPA, 2005). A concentração de Cloro para o tratamento da água, tornando a potável para consumo animal, humano e higienização da ordenha, deve ser 0,2 mg/L de cloro residual livre.

Além disso, segundo a EMBRAPA (2016), as características físico-químicas da água são fatores de grande relevância no processo de limpeza. A utilização de água rica em sais de cálcio e magnésio é o principal componente que afetará o processo de limpeza, uma vez que o produto só promoverá efeito de higienização após neutralizar estes sais.

\subsubsection{Limpeza do equipamento de ordenha, utensílios e tanque}


A limpeza correta dos utensílios e equipamentos da ordenha auxilia na produção de leite com qualidade. O leite ordenhado mecanicamente deixa resíduos nas tubulações, podendo ser uma fonte de contaminação para o leite, aumentando a CBT (EMBRAPA, 2016). Portanto, para garantir uma baixa contaminação, o equipamento deve ser limpo e higienizado com concentração de detergentes específicos, tempo de ação e temperatura correta, velocidade e turbulência das soluções de limpeza e drenagem adequada. (SANTOS, 2007).

Segundo a EMBRAPA (2016), existem dois tipos de resíduos que se acumulam nos equipamentos de ordenha:

a) Os Orgânicos: como as proteínas, gorduras e lactose. Podem ser removidos por soluções de produtos alcalino e alcalino clorado.

b) Os inorgânicos: como os minerais: Cálcio, Magnésio, Sódio, Potássio, etc. Estes resíduos formam na tubulação as chamadas "pedra do leite" e são removidos por produtos de concentração ácida.

Os depósitos de constituintes do leite no equipamento de ordenha se processam na forma de películas que são provenientes de reações bioquímicas, em que os componentes orgânicos se ligam na presença de um mineral (proveniente da água e do leite). Esta película é um excelente substrato para as bactérias favorecendo o ambiente onde elas podem se multiplicar.

Santos (2007) também recomenda o início da limpeza imediatamente após a ordenha, pois neste momento as tubulações estão mornas e não ocorreu formação de depósito de resíduos. Deve-se desconectar a tubulação de leite do tanque resfriador e deixar drenar todo resíduo da unidade final e bomba de leite.

Além disso, para sistemas de ordenha com limpeza por circulação, recomendase a limpeza manual externa das unidades finais e mangueiras, antes de acoplar as unidades de ordenha na linha de limpeza.

O Procedimento de limpeza segundo EMBRAPA (2016), é orientado conforme descrito a seguir:

a) Enxágue inicial: o enxágue com água morna (de $38^{\circ}$ a $43^{\circ} \mathrm{C}$ ), não recircular esse enxágue e descartar a água após a passagem pelo equipamento. Nesta etapa não deve utilizar água na temperatura ambiente $\left(18^{\circ}\right.$ a $\left.25^{\circ} \mathrm{C}\right)$, pois a gordura pode se fixar nas paredes do equipamento, uma vez que ela se solidifica. 
b) Limpeza com detergente alcalino clorado: a temperatura inicial deve ser de $75^{\circ}$ a $77^{\circ} \mathrm{C}$ e no final do ciclo não $<43^{\circ} \mathrm{C}$. Caso a temperatura do ciclo final esteja inferior a $43^{\circ} \mathrm{C}$ pode ocorrer deposição da fração sólida removida no início do ciclo (em temperatura alta).

Além disso, algumas recomendações para esta etapa estarão expostas a seguir:

- Duração de aproximadamente 10 minutos,

- $\quad$ Alcalinidade recomendada: para a solução é de 250 a 300 ppm;

- $\quad$ Conteúdo de compostos clorados varia de 50 a 80 ppm de $\mathrm{NaOCl}$ (hipoclorito de sódio).

- $\quad \mathrm{O}$ pH desta solução deve estar entre 10,0 e 11,5.

- Os detergentes devem ser adquiridos de firmas idôneas, sempre acompanhando o prazo de validade e guardados em local seguro.

- Após a circulação com detergente alcalino, deve ser realizada uma passagem da água em temperatura ambiente sem recircular, para tirar os restos de solução de limpeza.

c) Limpeza com detergente ácido: Os detergentes ácidos têm a função de remover os minerais provenientes do leite e da água utilizada na limpeza. A frequência do uso do detergente ácido depende da dureza da água, ou seja, águas ricas em minerais, acima de 150 ppm de CaCO3, o enxágue deve ser diário; abaixo de 150 ppm de $\mathrm{CaCO} 3$, a frequência pode ser semanal. Deixar a solução circular por cinco minutos com água morna $\left(35\right.$ a $45^{\circ} \mathrm{C}$ ) ou temperatura ambiente. $\mathrm{O}$ pH desta solução deve estar entre 3,0 e 4,0.

d) Desinfecção ou sanitização: esta etapa deve ser realizada de vinte a trinta minutos antes de iniciar a ordenha. A concentração do hipoclorito de sódio (150 ppm de cloro) à temperatura ambiente $\left(18\right.$ a $\left.25^{\circ} \mathrm{C}\right)$, deixando circular por cinco minutos. O objetivo desta sanitização é eliminar as bactérias que sobreviveram durante a limpeza e se desenvolveram durante o intervalo das ordenhas. Após a sanitização, não realizar o enxágue, apenas a drenagem (retirar o excesso de solução que pode ter ficado na tubulação).

O vácuo, ao passar do balde ou latão para o interior da tubulação, pode levar gotas de leite e formar incrustações no interior da tubulação, tornando-se focos de contaminação e dificultando o fluxo de ar. A Embrapa (2016) recomenda que a higiene 
da tubulação de vácuo deve ser realizada uma vez por mês, ou sempre que houver subida de leite para tubulação de vácuo.

O tanque de expansão deve ser imediatamente limpo após a retirada do leite. Todas as etapas utilizadas na limpeza de equipamentos de ordenha também devem ser seguidas na higienização dos tanques de resfriamento do leite. Uma limpeza inadequada do tanque de refrigeração pode levar à ocorrência de alta CBT no leite (EMBRAPA, 2016).

A orientação de limpeza manual de acordo com a EMBRAPA (2016) para equipamentos de balde ao pé, é através de detergente, escovas apropriadas e água. A escova exerce uma ação mecânica de grande importância. As escovas devem ser de boa qualidade, não muito duras a ponto de danificarem as borrachas. Na limpeza manual o detergente deve ser espumante para auxiliar na dispersão e na remoção dos resíduos da superfície, mantendo-o em suspensão.

É importante citar que, para utilização dos produtos de limpeza e desinfecção, recomenda-se que o ordenhador use aventais, luvas, botas e óculos de segurança. Em caso de contato com os olhos ou a pele, lavar com água em abundância, por no mínimo, 15 minutos.

\subsubsection{Tipos de microrganismos e a importância da cadeia de Frio}

As bactérias que contaminam o leite podem ser divididas em três grupos principais: psicrófilas, mesófilas e termófilas. A faixa ótima de crescimento da psicrófila se encontra entre 0 e $15^{\circ} \mathrm{C}$; a das mesófilas entre 20 e $40^{\circ} \mathrm{C}$; e a das termófilas entre 44 e $55^{\circ} \mathrm{C}$. Independente da temperatura ótima de crescimento, as bactérias têm diferentes capacidades de crescimento de acordo com a temperatura ambiente: as psicrotróficas e as termodúricas. As psicrotróficas são capazes de crescer em baixas temperaturas, ou seja, menores que $7^{\circ} \mathrm{C}$, entretanto a temperatura ótima de crescimento está entre 20 e $40^{\circ} \mathrm{C}$. Já as termodúricas correspondem ao grupo de bactérias capazes de resistir ao processo térmico de pasteurização $\left(72\right.$ a $\left.74^{\circ} \mathrm{C}\right)$ e possuem capacidade de crescimento em temperaturas de 4 a $7^{\circ} \mathrm{C}$ (EMBRAPA, 2016; SANTOS; FONSECA, 2007; PASSOS, 2003).

Em situações de higiene deficiente na ordenha e ausência de resfriamento do leite, há predomínio de bactérias mesófilas no leite, as quais fermentam a lactose e 
produzem ácido láctico e outros ácidos orgânicos, que elevam a acidez do leite e causam a coagulação da caseína (PASSOS, 2003).

O resfriamento é uma das etapas mais importantes para garantir a qualidade do leite na propriedade, pois reduz custos operacionais de produção, incluindo a deterioração do leite por atividade acidificante de bactérias mesófilas, possibilitando um maior tempo de armazenagem. Entretanto, pode ocasionar problemas tecnológicos associados à atividade de enzimas proteolíticas e lipolíticas de bactérias psicrotróficas (PINTO; MARTINS; VANETTI, 2006).

O tempo prolongado de armazenagem em temperaturas de refrigeração, associado com resfriamento inadequado do leite (resfriamento à temperatura entre 5 e $15^{\circ} \mathrm{C}$ ) e deficiência da higiene na ordenha favorecem o crescimento e o predomínio dos microrganismos psicrotróficos. Embora grande parte desses microrganismos seja destruída pela pasteurização, com exceção dos termodúricos, esse grupo apresenta capacidade de produção de enzimas proteolíticas e lipolíticas termorresistentes, que degradam os componentes do leite e mantém sua atividade enzimática mesmo depois da pasteurização ou mesmo o tratamento UHT (ultra high temperature), podendo resultar em coagulação do leite, desenvolvimento de sabor e odor alterado, redução de rendimento na produção de derivados e redução do tempo de prateleira dos produtos lácteos (SANTOS; FONSECA, 2007; PASSOS, 2003).

Portanto, a condição higiênica da produção do leite, manejo adequado, limpeza eficiente e manutenção preventiva e programada dos equipamentos de ordenha, qualidade da água e resfriamento são fundamentais para obtenção de um leite com qualidade e baixo grau de contaminação bacteriana.

O leite deve ser resfriado imediatamente após a ordenha para temperatura de aproximadamente $4^{\circ} \mathrm{C}$, dentro de duas horas. Além disso, após o leite ter sido ordenhado, resfriado e armazenado, esse pode permanecer na propriedade leiteira e ser recebido no estabelecimento industrial por um período máximo de até 48 horas (BRASIL, 2011).

A temperatura máxima de chegada do leite na recepção das unidades de processamento é de $10^{\circ} \mathrm{C}$, onde após liberação da recepção e descarregamento do produto, o mesmo é submetido à refrigeração a $4^{\circ} \mathrm{C}$ e enviado ao tanque de estocagem (BRASIL, 2011).

A CBT indica as condições gerais de higiene de ordenha e dos utensílios utilizados bem como da refrigeração, transporte e armazenamento do leite. Com isso, 
para identificar a ineficiência do manejo e higienização dos processos de toda cadeia, é necessário que sejam coletadas amostras do tanque de expansão do produtor, dos compartimentos do caminhão e do silo de armazenamento do laticínio para realizar análise de CBT. Deste modo, com rastreabilidade do processo, pode-se identificar em qual etapa está havendo perda considerável da qualidade, por contaminação bacteriana.

\subsubsection{A Qualidade do Leite no Transporte}

De acordo com Teixeira e Ribeiro (2000), o transporte a granel implica em coletar o leite produzido em uma ou mais propriedades (conforme capacidade do tanque do caminhão e volume captado nas propriedades), por meio de um tanque com dupla camada, dividido internamente por compartimentos, material de aço inox, com característica isotérmica. É instalada no veículo, uma bomba de sucção que transfere o leite do tanque de resfriamento para o tanque isotérmico de transporte.

Este sistema exige que o leite seja refrigerado na unidade de produção. O local do tanque na fazenda deve ser de fácil acesso ao veículo coletor, além disso, deve ser coberto e pavimentado, arejado, com iluminação, provido de água de boa qualidade e mantido limpo e higienizado (BRASIL, 2011).

O Agente de Coleta de leite, o qual geralmente é o motorista, deve trabalhar devidamente uniformizado, além de estar apto a realizar as análises de rotina e possuir hábitos higiênicos (BRASIL, 2011).

Antes de iniciar a coleta do leite, o agente de coleta deve realizar testes e medições para certificar se o leite está próprio para coleta ou não. O alizarol é um indicador de $\mathrm{pH}$, estabilidade de proteínas e térmica do leite e faz parte da rotina de análise do agente de coleta. De acordo com Fonseca e Santos (2007), a amostra de leite é cuidadosamente misturada a uma solução alcoólica contendo um indicador de pH (alizarina) e observa-se se ocorre a formação de um precipitado, ou coagulação.

De acordo com Fonseca e Santos (2007), possíveis causas de resultado positivo no teste podem estar associadas a:

- Um aumento na acidez do leite, causada pela multiplicação crescimento de bactérias, fermentação e liberação de ácidos;

- Ação de microrganismos sobre a caseína; 
- Desequilíbrio nutricional na relação Ca:P e outros desequilíbrios de minerais;

- Elevada porcentagem de vacas com mastite;

- Presença de colostro;

- Concentração de vacas no final de lactação.

Ao coletar a amostra, o agente de coleta deve homogeneizar o leite através do agitador automático do tanque de expansão por, no mínimo, 5 minutos. Para tanques com mais de 3 mil litros este tempo deve ser aumentado para dez minutos. Após a homogeneização, transferir o leite para o frasco como auxilio de uma concha (CASSOLI; MACHADO, 2006), registrar a temperatura e volume do leite e a aprovação ou não, de acordo com os testes do Alizarol e medição da temperatura, em formulário adequado (BRASIL, 2011).

O agente de coleta deve coletar uma amostra diária do leite do tanque do produtor, identificar o frasco e armazenar em caixa térmica dotada de termogel (gelo reutilizável). Esta amostra compõe as contraprovas de rastreabilidade que são utilizadas caso haja algum problema de qualidade no tanque do caminhão, tornando possível a identificação do produtor e o desenvolvimento de um plano de ação diante de um incidente na qualidade (ABNT, 2006). Isto acontece, porque na recepção de leite são feitas provas de plataforma, as quais não são feitas no momento de coleta, devido à complexidade e necessidade de equipamentos específicos.

Ao aprovar a coleta do leite, o agente de coleta deve fazer a sanitização do engate da mangueira e da saída do tanque de expansão ou da ponteira coletora de aço inoxidável. A transferência do leite do tanque de refrigeração por expansão direta para o carro-tanque deve se processar sempre em circuito fechado (BRASIL, 2011).

O leite que apresentar qualquer anormalidade ou não estiver refrigerado até a temperatura máxima admitida pela legislação em vigor não deve ser coletado a granel (BRASIL, 2011).

Os caminhões de transporte do leite devem ser lavados externamente antes do descarregamento e higienizados internamente após cada descarga (BRASIL, 2011).

É importante ressaltar que a IN 62 admite o transporte de leite em latões em temperatura ambiente, desde que o estabelecimento processador concorde em aceitar trabalhar com essa matéria-prima; que esta matéria-prima atenda as exigências microbiológica, físicas e químicas descritas nas Tabelas 1 e 2 (citadas 
anteriormente); o leite deve ser entregue no estabelecimento processador no máximo até $2 \mathrm{~h}$ (duas horas) após a conclusão da ordenha (BRASIL, 2011).

\subsubsection{O Controle da Qualidade do Leite Cru Refrigerado na Recepção}

A recepção do leite na indústria deve contar com laboratórios devidamente equipados para a realização do controle físico-químico e microbiológico do leite e demais produtos. O leite do conjunto de produtores, quando do seu recebimento no Estabelecimento Beneficiador, deve ser coletado a amostra de cada compartimento do tanque para a realização das análises requeridas IN51 (BRASIL, 2002), as quais permanecem as mesmas na IN 62 (BRASIL, 2011), conforme citado anteriormente.

Os limites das análises de recepção de leite estão detalhados nas tabelas 2 e 3 (citadas anteriormente). A IN 62 (BRASIL, 2011) informa que o leite do produtor cujas análises revelarem resultados fora do padrão deve ser, obrigatoriamente, submetido à nova coleta para análises em até 30 (trinta) dias. Além disso, o produtor deve ser comunicado da anormalidade para que adote as ações corretivas necessárias para o atendimento aos padrões de qualidade do leite. O leite que não atenda aos requisitos de qualidade deve sofrer destinação conforme Plano de Controle de Qualidade do estabelecimento, que deve tratar da questão baseando-se nas Normas de Destinação do Leite e Derivados.

\subsubsection{Garantia da Qualidade do Leite na Indústria ou Usina de Beneficiamento do Leite}

De acordo com a Resolução No 10 de 22/05/2003 do MAPA (BRASIL, 2003), as principais ferramentas usadas na atualidade para a garantia da inocuidade, qualidade e integridade dos alimentos de origem animal são:

- Boas Práticas de Fabricação (BPF);

- Procedimentos - Padrão de Higiene Operacional (PPHO)

- Análise de Perigos e Pontos Críticos de Controle (APPCC)

A Portaria 46 do MAPA, Brasil (1998), obrigou a implantação gradativa em todas as indústrias de produtos de origem animal do programa de garantia de qualidade APPCC, cujo pré-requisito essencial são as BPFs os PPHOs. 
O PPHO são procedimentos desenvolvidos, implantados e monitorizados, visando estabelecer a forma rotineira pela qual o estabelecimento industrial evitará a contaminação direta ou cruzada e a adulteração do produto, preservando sua qualidade e integridade por meio da higiene antes, durante e depois das operações industriais (BRASIL, 2003).

A implementação do Plano PPHO deve cumprir os seguintes critérios (BRASIL, 2003):

- Treinamento e Capacitação de Pessoal;

- Condução dos procedimentos antes, durante e após as operações;

- Monitoramento e avaliações rotineiras dos procedimentos e de sua eficiência;

- Revisão das ações corretivas e preventivas em situações de desvios e alterações tecnológicas dos processos industriais.

O plano PPHO deve ser estruturado diante dos 9 pontos básicos:

1. Segurança da água;

2. Condições e higiene das superfícies de contato com o alimento;

3. Prevenção contra a contaminação cruzada;

4. Higiene dos empregados;

5. Proteção contra contaminantes e adulterantes do alimento;

6. Identificação e estocagem adequadas de substâncias químicas e de agentes tóxicos;

7. Saúde dos empregados;

8. Controle integrado de pragas;

9. Registros.

De acordo com a Agência Nacional de Vigilância Sanitária (ANVISA), a implantação das Boas Práticas é uma exigência legal e deve ser um objetivo estratégico da empresa que busca oferecer um produto que satisfaça a necessidade da população e atenda aos padrões sanitários exigidos.

A Portaria n¹428 de 26/11/93 do Ministério da Saúde (MS) define Boas Práticas de Fabricação como "normas e procedimentos que visem atender a um determinado padrão de identidade e qualidade de um produto ou serviço" e que consiste na apresentação de informações referentes aos seguintes aspectos básicos:

a) Padrão de Identidade e Qualidade - PIQ; 
b) Condições Ambientais;

c) Instalações e Saneamento;

d) Equipamentos e Utensílios;

e) Recursos Humanos;

f) Tecnologia Empregada;

g) Controle de Qualidade;

h) Garantia de Qualidade;

i) Armazenamento;

j) Transporte;

k) Informações ao Consumidor;

I) Exposição / Comercialização;

m) Desinfecção / Desinfestação (BRASIL, 1993).

O sistema de APPCC tem como objetivo identificar, avaliar e controlar os perigos para a saúde do consumidor e caracterizar os pontos e controles considerados críticos para assegurar a inocuidade dos alimentos. Estes perigos podem ser por contaminação microbiológica, química ou física (QUEIROZ; ANDRADE, 2010).

Os perigos biológicos compreendem bactérias patogênicas e suas toxinas, vírus, parasitas e protozoários envolvidos em surtos de doenças de origem alimentar (QUEIROZ; ANDRADE, 2010).

Segundo a Embrapa (2016), os perigos biológicos graves no leite e derivados incluem: Brucella spp., Clostridium botulinum, Listeria monocytogenes, Salmonella Typhi, Salmonella Paratyphi, Salmonella Dublin, Shigella dysenteriae e os vírus das hepatites A e E. Os perigos biológicos moderados, com potencial de disseminação ampla, incluem: Salmonella spp., Escherichia coli, E. coli enteroinvasiva, E. coli 0157:H7, Shigella spp., vários tipos de vírus e Cryptosporidium spp. Os perigos biológicos classificados como moderados e com disseminação limitada, incluem Bacillus cereus, Campylobacter jejuni e outras espécies, Clostridium perfringens, Staphylococcus aureus, Aeromonas spp., Yersinia enterocolitica e parasitas.

Os perigos físicos incluem cacos de vidro, madeiras, metais, fios de cabelo ou outros objetos que podem causar injúrias ou até mesmo necessitar de intervenções cirúrgicas. Os perigos químicos compõem os antibióticos, defensivos agrícolas, 
anabolizantes, resíduo de produtos sanitizantes/desinfetantes (QUEIROZ; ANDRADE, 2010).

Ao elaborar o Plano APPCC, a sequência preliminar inicia-se pela definição de objetivos, identificação do organograma da empresa (listagem dos membros das equipes), descrição do produto e uso esperado, elaboração do fluxograma do produto (com descrição de cada etapa do processo), validação do fluxograma (RIBEIROFURTINI; ABREU, 2006). Além desses passos, o APPCC é composto por sete princípios que controlam os perigos a saúde do consumidor, conforme descritos abaixo de acordo com Queiroz e Andrade (2010):

$1^{\circ}$ Princípio: Análise de Perigos e Medidas de Controle - Nesta fase são identificados todos os perigos físicos, químicos e microbiológicos em cada uma das etapas dos processos, matéria-prima e ingredientes. Verificam-se quais perigos são controlados pelos programas de pré-requisitos e são denominados Pontos de Controle (PCs);

$2^{\circ}$ Princípio: Identificação dos Pontos Críticos de Controle (PCC): Os perigos identificados no $1^{\circ}$ princípio que não são controlados pelo programa de Pré Requisitos são considerados PCCs. Com o auxilio de uma árvore decisória (Figura 11), determina-se se é um PCC ou um PC. Os pontos considerados como PCCs devem ser identificados e enumerados no fluxograma; 
Figura 11 - Árvore decisória usada para a identificação dos PCC's

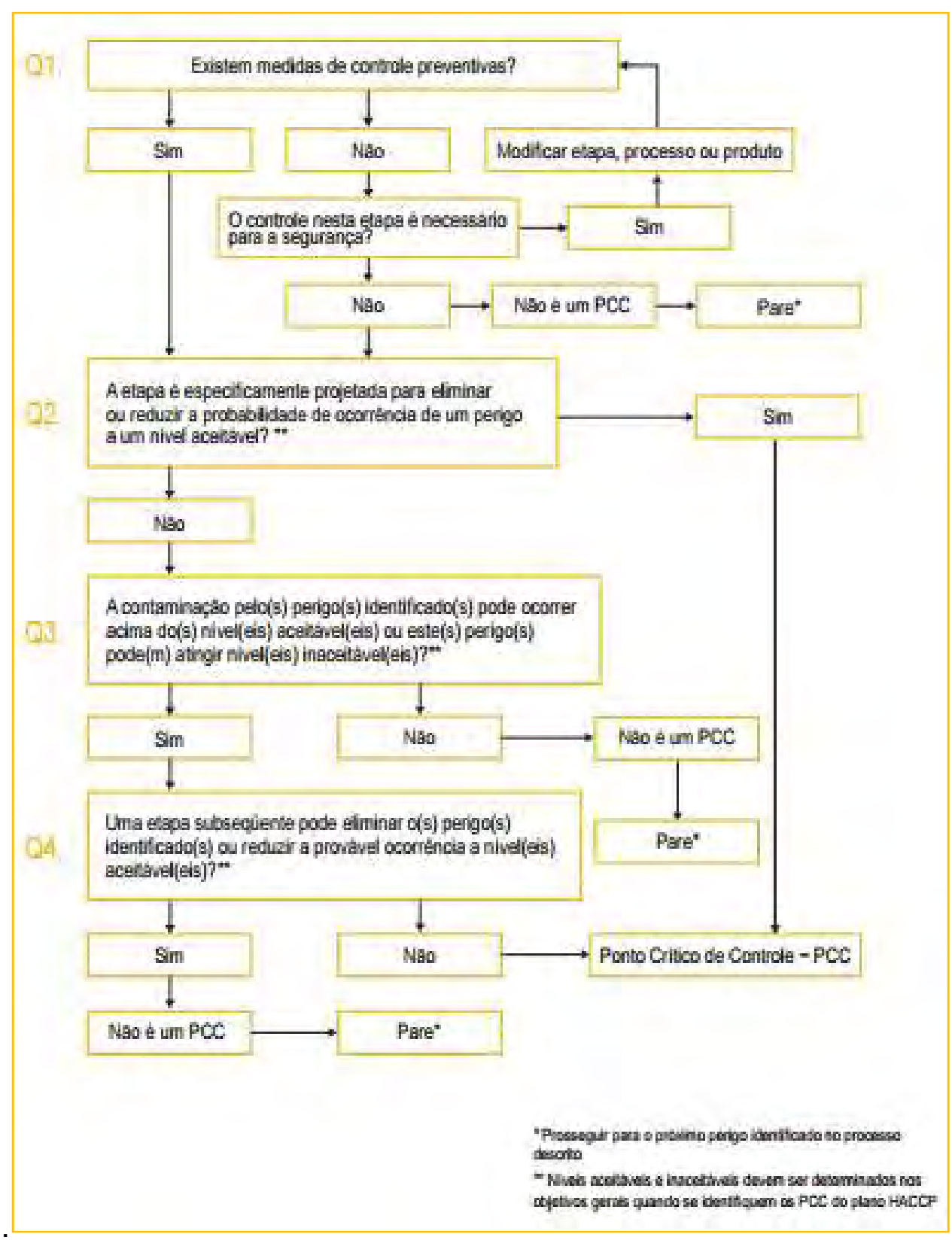

Fonte: Organização Pan-Americana da Saúde. Higiene dos Alimentos - Textos Básicos. Agência Nacional de Vigilância Sanitária; Food and Agriculture Organization of the United Nations. - Brasília. 2006. $64 \mathrm{p}$.

$3^{\circ}$ Princípio: Estabelecimento dos limites críticos - É o valor associado ao PCC através de um controle que mantém o processo seguro (Ex. Tempo, Temperatura, pH. Acidez Titulável, etc);

$4^{\circ}$ Princípio: Estabelecimento dos Procedimentos de monitorização - O primeiro passo é determinar o que monitorar, quando, como e quem será o responsável, que deverá ser treinado e capacitado para esta tarefa, ou seja, é a 
observação ou mensuração para avaliar se um determinado PCC está sob controle e para gerar dados de registro fiel para uso futuro na verificação;

. $5^{\circ}$ Princípio: Estabelecimento das ações corretivas - As ações corretivas específicas devem ser desenvolvidas para cada PCC de forma a controlar um desvio nos limites críticos ou na faixa de segurança, a fim de garantir a segurança nos processos;

$6^{\circ}$ Princípio: Estabelecimento dos processos de verificação - Nesta fase, é feita uma revisão de todos os procedimentos de monitoramento e análises microbiológicas para garantir que os PCCs estão sob controle, verifica-se também as ações corretivas, treinamentos, entre outros. Esta revisão tem o objetivo de adequar todos os registros e avaliar se algumas determinações estão sendo muito rigorosas;

$7^{0}$ Princípio: Estabelecimento dos processos de registro - Todo tipo de documentação gerado no sistema APPCC e estes devem ser mantidos datados, assinados e disponíveis quando necessário para comprovação de seu funcionamento correto. Quando for para validação do plano ou auditoria, os princípios 6 e 7 podem inverter sua ordem.

Considerando o processamento do leite até a pasteurização, conforme o Quadro 1 foram encontrados dois Pontos Críticos de Controle sendo um de origem Química na recepção do leite devido a possibilidade da presença de antibiótico no leite e outro de origem Biológica devido a possibilidade de sobrevivência de microrganismos patogênicos na pasteurização.

Santos e Fonseca (2007) relatam que as razões para evitar a ocorrência de resíduos de antibióticos no leite, no aspecto toxicológico, incluem a possibilidade de esses resíduos causarem reações alérgicas nos consumidores. Além disso, algumas drogas apresentam atividade carcinogênica ou mutagênica, como os nitrofuranos, o clorafenicol e a sulfametazina. Outro fator é a ocorrência de resíduos de antibióticos trazerem resistência bacteriana.

No aspecto tecnológico, os resíduos de antibióticos podem tornar impróprio o leite para a produção de fermentados, principalmente iogurtes e queijos, pois as culturas lácteas utilizadas na fabricação desses produtos são sensíveis a determinados níveis de antibióticos encontrados no leite, causando consideráveis perdas econômicas para a indústria processadora (SANTOS; FONSECA, 2007).

Na pasteurização foi determinado um perigo de natureza biológica, pois o leite 
in natura chega com elevada carga microbiana, e a pasteurização é a única forma de controlar esse risco, não havendo outra etapa subsequente efetiva para a eliminação de micro-organismos patogênicos.

A etapa de pasteurização é um PCC, pois não há etapa anterior ou posterior efetiva para a redução de microrganismos patogênicos a um nível aceitável e, o ítem a ser controlado (binômio tempo/temperatura) não faz parte do programa de prérequisitos. Portanto, a medida de controle deste perigo será a correta execução do binômio tempo/temperatura de pasteurização. Isso será evidenciado e registrado através de controles de medição de temperatura pela carta gráfica do pasteurizador.

O Quadro 1 apresenta os perigos e pontos críticos de controle (PCC) do processamento do leite pasteurizado destacando o PCC biológico e químico e suas medidas de controle.

Quadro 1 - Determinação de perigos e pontos críticos de controle do processamento do leite pasteurizado.

\begin{tabular}{|c|c|c|c|}
\hline $\begin{array}{c}\text { ETAPAS DO } \\
\text { PROCESSO }\end{array}$ & $\begin{array}{c}\text { IDENTIFICAÇÃO DO } \\
\text { PERIGO }\end{array}$ & $\begin{array}{c}\text { MEDIDAS DE } \\
\text { CONTROLE }\end{array}$ & PCC \\
\hline \multirow{2}{*}{ Recepção do Leite } & Antibiótico (Q) & $\begin{array}{c}\text { Realização de testes para } \\
\text { verificação da presença de } \\
\text { antibiótico }\end{array}$ & Não \\
\cline { 2 - 4 } & $\begin{array}{c}\text { Multiplicação de micro- } \\
\text { organismo patogênico (B) }\end{array}$ & Pasteurização & Não \\
\hline \multirow{3}{*}{ Resfriamento/Estocagem } & $\begin{array}{c}\text { Multiplicação de micro- } \\
\text { organismos patogênicos (B) }\end{array}$ & Pasteurização & Não \\
\cline { 2 - 4 } & Toxinas (Q) & Controle de temperatura & Sim \\
\hline \multirow{2}{*}{ Pasteurização } & Sobrevivência de micro- & Controle de tempo e \\
temperatura & \\
\hline
\end{tabular}

Fonte: ZANIOLO, J. A. Implantação do Sistema APPCC na Produção de Queijo Tipo Muçarela. Enciclopédia Biosfera, Centro Científico Conhecer - Goiânia, v.11 n.22; p. 2015.

No Quadro 2 pode ser verificado os PCCs e seus respectivos limites críticos, monitoramento, ação corretiva e verificação para garantir o controle e a efetividade dos controles e a não ocorrência dos riscos nas etapas da recepção do leite e pasteurização. 
Quadro 2 - Mapa descritivo dos pontos críticos de controle do processamento de Leite pasteurizado.

\begin{tabular}{|l|l|l|l|l|l|l|}
\hline PCC & PERIGO & $\begin{array}{l}\text { PONTO DE } \\
\text { CONTROL } \\
\text { E }\end{array}$ & $\begin{array}{l}\text { LIMÍTE } \\
\text { CRíTICO }\end{array}$ & $\begin{array}{l}\text { MONITORAMENT } \\
\text { O }\end{array}$ & $\begin{array}{l}\text { AÇÃO } \\
\text { CORRETIV } \\
\text { A }\end{array}$ & $\begin{array}{l}\text { VERIFICAÇÃ } \\
\text { O }\end{array}$ \\
\hline $\begin{array}{l}\text { RECEPÇÃO DO } \\
\text { LEITE }\end{array}$ & $\begin{array}{l}\text { Resíduo de } \\
\text { antibiótico }\end{array}$ & $\begin{array}{l}\text { Teste de } \\
\text { detecção de } \\
\text { resíduos }\end{array}$ & Ausência & $\begin{array}{l}\text { Teste de detecção } \\
\text { de antibiótico por } \\
\text { compartimento dos } \\
\text { tanques de todos } \\
\text { os caminhões }\end{array}$ & $\begin{array}{l}\text { Descarte } \\
\text { adequado do } \\
\text { leite e } \\
\text { comunicaçã } \\
\text { o aos } \\
\text { fornecedores }\end{array}$ & $\begin{array}{l}\text { Verificação da } \\
\text { técnica e da } \\
\text { validade dos } \\
\text { kits }\end{array}$ \\
\hline $\begin{array}{l}\text { PASTEURIZAÇÃ } \\
\mathbf{O}\end{array}$ & $\begin{array}{l}\text { Sobrevivência } \\
\text { de } \\
\text { microrganismo } \\
\text { s patogênicos }\end{array}$ & $\begin{array}{l}\text { Binômio: } \\
\text { tempo e } \\
\text { temperatura }\end{array}$ & $\begin{array}{l}72 \text { a } \\
75^{\circ} \mathrm{C} \text { por } \\
10 \text { a 15 } \\
\text { segundo } \\
\text { s }\end{array}$ & $\begin{array}{l}\text { Inspeção do } \\
\text { marcador de } \\
\text { temperatura e } \\
\text { tempo de retenção } \\
\text { do leite }\end{array}$ & $\begin{array}{l}\text { Ajuste de } \\
\text { tempo e } \\
\text { temperatura }\end{array}$ & $\begin{array}{l}\text { Aferição de } \\
\text { equipamentos } \\
\text { e instrumentos; } \\
\text { pesquisa de } \\
\text { peroxidase e } \\
\text { fosfatase }\end{array}$ \\
\hline
\end{tabular}

Fonte: ZANIOLO, J. A. Implantação do Sistema APPCC na Produção de Queijo Tipo Muçarela. Enciclopédia Biosfera, Centro Científico Conhecer - Goiânia, v.11 n.22; p. 2015.

\section{MATERIAIS E MÉTODOS}

De acordo com o objetivo da pesquisa e sua abrangência, pode-se defini-la como pesquisa descritiva, uma vez que descreve e analisa, particularmente, o Programa Qualileite da Danone. No entanto, para a consecução dos objetivos propostos, foram utilizados métodos tanto de abordagem qualitativa como quantitativa, em diferentes momentos, porém, com propósitos complementares. Deste modo, obtém-se uma avaliação completa, possibilitando avaliar o programa como um todo, buscando melhoria continua em sua execução.

A pesquisa descritiva compreende os levantamentos de campo, seja por questionamento verbal ou escrito e serve para que o pesquisador obtenha informações dos entrevistados (MALHOTRA et al., 2005). Neste trabalho foram adotados os procedimentos de estudo de caso (YIN, 2005), utilizando-se técnicas de entrevistas semiestruturadas com líderes e técnicos das cooperativas envolvidas (Corples, Coopas e Cooperativa "X"), com o intuito de avaliar erros e acertos do Programa Qualileite Danone.

O trabalho de campo consistiu na implantação e acompanhamento do Programa Qualileite em cooperativas fornecedoras à Danone e posterior coleta de dados para avaliação dos resultados quantitativos e qualitativos (Figura 12). 
Figura 12 - Etapas do trabalho de campo

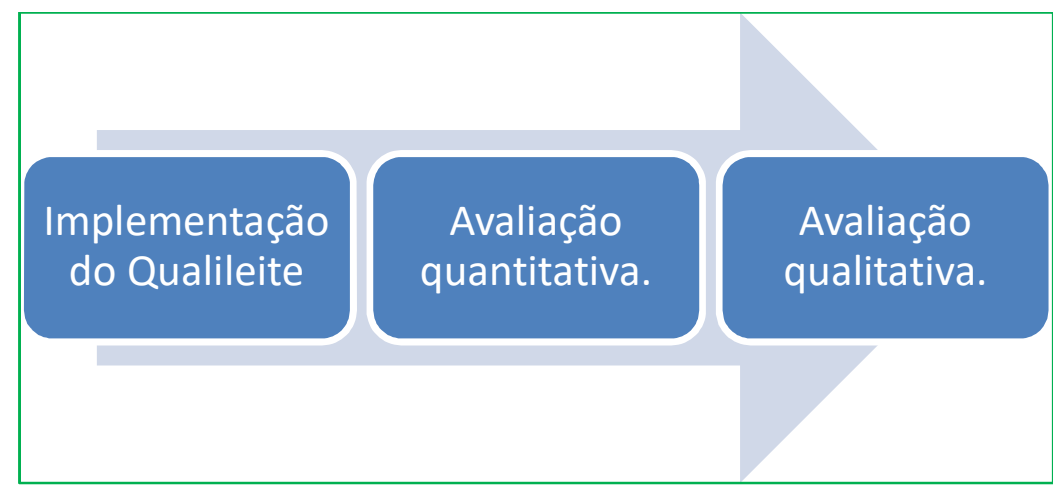

Fonte: Própria autoria

Os procedimentos de abordagem quantitativa estão restritos à análise dos critérios objetivos de qualidade do leite, após a implantação do Programa Qualileite Danone, nas respectivas cooperativas que fizeram parte desta pesquisa. A Figura 13 ilustra as diferentes abordagens utilizadas na pesquisa e seus respectivos propósitos.

Figura 13 - Abordagens metodológicas utilizadas na pesquisa
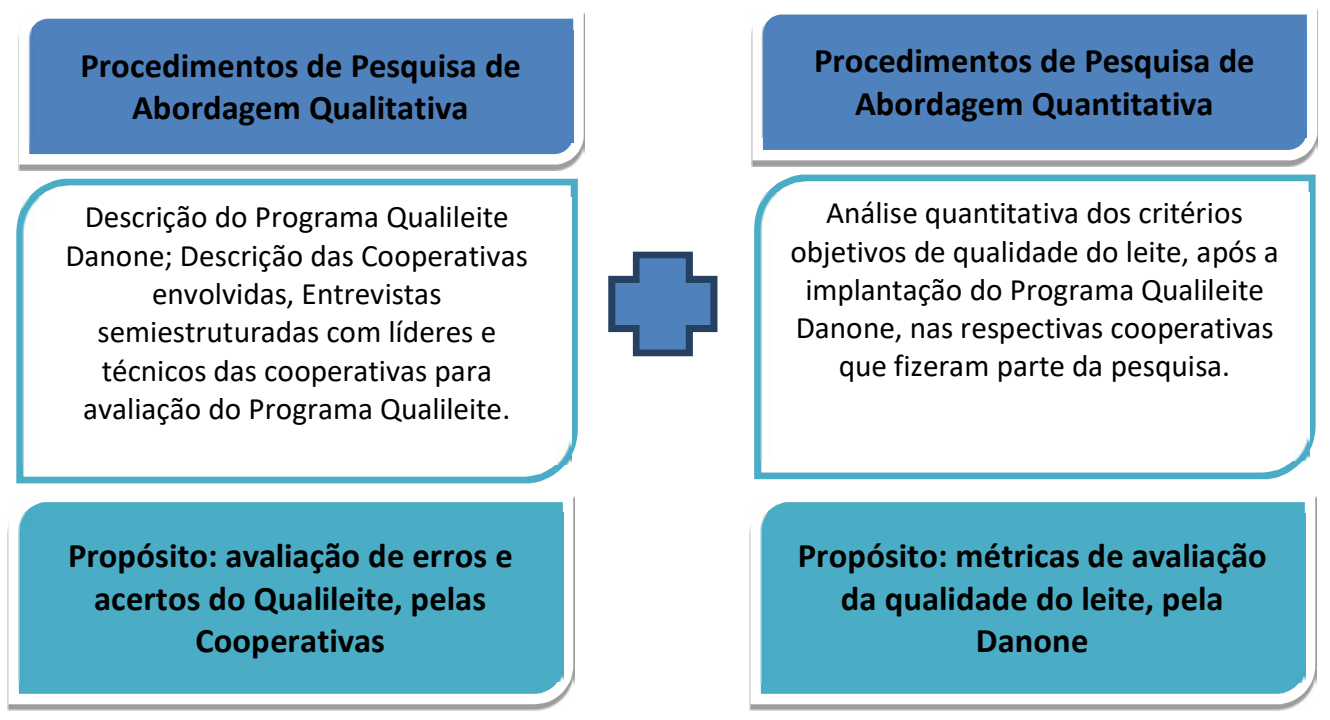

Fonte: Própria autoria

\subsection{Descrição das cooperativas participantes do Programa Qualileite}

O Programa Qualileite foi aplicado em três cooperativas fornecedoras de leite à Planta de Poços de Caldas - MG da Danone, ambas localizadas no Sul de Minas Gerais, sendo elas a Cooperativa Regional de Produtores de Leite de Serrania (Corples), Cooperativa dos Produtores Agropecuaristas de Santa Rita de Caldas 
(Coopas) e Cooperativa " $\mathrm{x}$ ", as quais suas características estão descritas conforme Tabela 5. O volume de leite provido das cooperativas do programa Qualileite representa $33 \%$ do volume total fornecido à Danone por cooperativas.

Tabela 5 - Características das cooperativas participantes do programa Qualileite.

\begin{tabular}{|c|c|c|c|}
\hline Características: & Corples & Coopas & Cooperativa $\mathrm{X}$ \\
\hline Volume de captação diária & 68000 & 35000 & 95000 \\
\hline No de Produtores & 309 & 220 & 540 \\
\hline Média volume produtor dia & 220 & 159 & 176 \\
\hline Volume médio entregue à Danone por dia em 2014. & 30.000 & 13.000 & 27.000 \\
\hline$\%$ Produtores tanque refrigerado individual & $73 \%$ & $100 \%$ & $85 \%$ \\
\hline \% Produtores tanque refrigerado comunitário & $27 \%$ & 0 & $15 \%$ \\
\hline \% Volume com frequência de coleta de leite 24 horas & $45 \%$ & 0 & 0 \\
\hline \% Volume com frequência de coleta de leite 48 horas & $55 \%$ & $100 \%$ & $100 \%$ \\
\hline Tempo de Rota (da 1a coleta até chegar na cooperativa). & $8 \mathrm{~h}$ & $5 \mathrm{~h}$ & $5 \mathrm{~h}$ \\
\hline Taxa de ocupação dos tanques de transporte de leite & $80 \%$ & $80 \%$ & $80 \%$ \\
\hline Condição dos Caminhões e tanques de transporte. & boa & boa & Ruim \\
\hline Lavagem externa do Caminhão? & $\operatorname{sim}$ & $\operatorname{sim}$ & Não \\
\hline Lavagem interna do tanque? & $\operatorname{sim}$ & $\operatorname{sim}$ & $\operatorname{Sim}$ \\
\hline Temperatura do leite ao chegar na cooperativa? & $\begin{array}{c}\text { entre } 4^{\circ} \mathrm{C} \text { a } \\
10^{\circ} \mathrm{C}\end{array}$ & $<7^{\circ} \mathrm{C}$ & $<10^{\circ} \mathrm{C}$ \\
\hline Estrutura de resfriamento do leite na cooperativa é eficiente? & $\operatorname{sim}$ & $\operatorname{sim}$ & Sim \\
\hline Início do programa: & jun/12 & jun/14 & $\mathrm{mar} / 14$ \\
\hline
\end{tabular}

Fonte: Programa Qualileite Danone

\subsubsection{Corples}

Localizada em Serrania, a Corples possui uma captação diária de 68.000 litros de leite/dia, sendo aproximadamente $50 \%$ deste volume são destinados à produção interna de leite pasteurizado, doce de leite, iogurte, requeijão e queijos. O volume excedente da produção é destinado à venda do leite cru refrigerado para laticínios, incluindo a Danone. Esta cooperativa possui 309 produtores de leite cooperados com média de produção diária de 220 litros, sendo que $27 \%$ do volume captado vêm de tanques comunitários, ou seja, cada tanque refrigerado armazena o leite de diversos produtores. Além disso, 55\% do volume captado são coletados a cada 48 horas e $45 \%$ a cada 24 horas.

O tempo médio de percurso das rotas da primeira coleta até chegar à cooperativa é de 8 horas. A taxa de ocupação dos tanques dos caminhões é de $80 \%$.

${ }^{2}$ Por motivos éticos e comerciais o nome da cooperativa "X" não será revelado. 
Ao chegar à cooperativa, o caminhão é lavado externamente antes de entrar na plataforma de analise da carga e descarga do leite e depois de descarregar é lavado internamente conforme procedimento adotado pela empresa. Para liberação do recebimento do leite na plataforma da cooperativa, todas as análises exigidas pela legislação são realizadas.

\subsubsection{Coopas}

Localizada em Santa Rita de Caldas, a Coopas possui um posto de resfriamento de leite com captação diária de 35.000 litros, com 220 produtores com média de produção diária de 160 litros. Todos os produtores possuem tanque de expansão individual, cuja coleta de leite é feita a cada 48 horas.

O tempo médio de percurso das rotas da primeira coleta até chegar à cooperativa é de 5 horas. A taxa de ocupação dos tanques dos caminhões é de $80 \%$. O caminhão ao chegar à cooperativa é lavado externamente e após descarregar o leite é lavado internamente conforme procedimento adotado pela empresa. Todas as análises exigidas pela legislação são realizadas para a liberação do recebimento do leite na plataforma da Cooperativa.

\subsubsection{Cooperativa " $X "$}

A Cooperativa " $X$ " é um laticínio que possui atualmente captação diária de 95.000 litros, é composta por 540 produtores de média de produção diária de 175 litros. Do total captado, $85 \%$ do leite é armazenado na propriedade em tanques individuais e o restante (15\%) em tanque comunitários. A coleta de leite é feita a cada 48 horas. O tempo médio de percurso das rotas da primeira coleta até chegar à cooperativa é de 5 horas. A taxa de ocupação dos tanques dos caminhões é de $80 \%$. A conservação desses tanques está em condições desfavoráveis, pois são antigos, amassados e, além disso, o caminhão ao chegar à cooperativa não é lavado externamente antes de entrar na plataforma de análise da carga e descarga do leite. Entretanto, depois de descarregar é lavado internamente conforme procedimento adotado pela cooperativa. Para liberação do recebimento do leite na plataforma da Cooperativa, todas as análises exigidas pela legislação são realizadas. 


\subsection{O Programa Qualileite da Danone}

O Programa Qualileite da Danone é focado em desenvolver a gestão da qualidade das cooperativas com objetivo de obter melhores resultados de CBT do leite recebido pela Danone.

A adesão das cooperativas no Programa Qualileite, ocorre de forma comercial, via contrato, no qual constam os acordos de fornecimento de volume diário, exigências de qualidade e cumprimento dos requisitos estipulados no programa. Consta como anexo ao contrato firmado, uma tabela ${ }^{3}$ de pagamento pela qualidade do leite, onde são especificadas, respectivamente, as bonificações em caso de resultados positivos e as penalizações em caso de resultados negativos. A partir do resultado da amostra da carga diária de leite, é estipulado o pagamento de acordo com o atendimento (ou não) aos critérios de qualidade estabelecidos no Qualileite. Além disso, existe uma bonificação de incentivo à participação no Qualileite de $R \$ 0,02 / L$, entretanto, para que a cooperativa receba esta bonificação de incentivo ao programa, ela deve cumprir as premissas do Qualileite, assim como as ações devem ser concluídas dentro do prazo e o objetivo atingido.

As premissas do Programa Qualileite são:

1. Comprometimento da Diretoria da cooperativa e do time técnico da cooperativa/laticínio com a melhoria continua e adequação da qualidade do leite aos padrões exigidos pela Danone;

2. Comprometimento da cooperativa/laticínio em replicar, para seus produtores, o modelo de gestão de qualidade do leite dos produtores da Danone;

3. Comprometimento da cooperativa/laticínio e da Danone em praticar o pagamento por qualidade do leite (Danone x cooperativa e cooperativa x produtores);

4. A cooperativa fornecedora de leite deve coletar no mínimo 3 (três) amostras mensais por produtor (composição+CBT), sendo que no mesmo dia que coleta amostra de produtor, deve haver coletas de rotas, no qual devem ser enviadas a um laboratório credenciado na Rede Brasileira de Laboratórios de Análise da Qualidade do Leite (RBQL), reconhecido pelo Ministério da Agricultura, Pecuária e Abastecimento (MAPA).

\footnotetext{
3 Por questões de confidencialidade exigida pela Danone, a tabela de pagamento pela qualidade do leite de cooperativas não será exposta.
} 
5. A cooperativa deverá disponibilizar um ponto focal ao programa para desenvolver a metodologia proposta pelo Qualileite e um time de campo para desenvolver os trabalhos de melhoria da qualidade.

6. Todas as visitas em produtores com problemas na qualidade devem ser registradas por meio de um Check-list de campo. Além disso, deve conter um relatório de ações com prazo e assinatura do produtor.

7. Deve haver um Check-list mensal dos caminhões, para verificar todos os pontos que podem prejudicar a qualidade da rota. As não conformidades devem ser corrigidas em curto prazo ou imediatamente.

8. Deve haver uma Instrução de Trabalho do procedimento de CIP (sigla em inglês Clean in Place) de todos os caminhões (após cada descarregamento) e tubulações (duas vezes ao dia), de modo que todas as concentrações e tempo de limpeza sejam cumpridos.

\subsection{Implementação do Programa Qualileite}

A implementação do Programa Qualileite nas cooperativas fornecedoras de leite à Danone está estruturado em seis passos, tendo como premissa teórica o modelo PDCA (Plan, Do, Check, Action), além de outras ferramentas de gestão da qualidade aplicadas para organizar dados, identificar causas dos problemas e desenvolver os planos de ações.

O fluxo de implementação do programa pode ser visualizado na Figura 14.

Figura 14 - Passo-a-passo de implementação do programa.

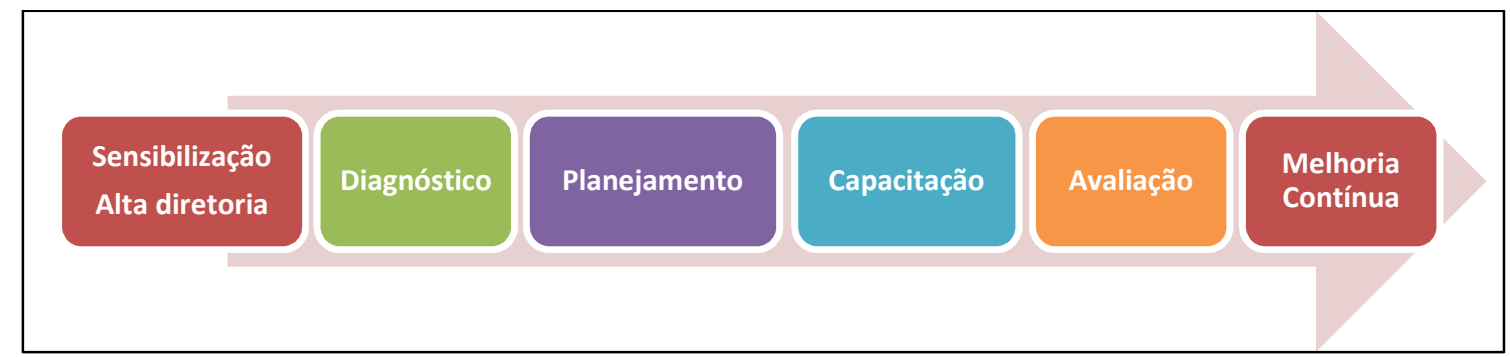

Fonte: Própria autoria 
A seguir estão detalhados cada um dos passos da implantação do Programa Qualileite.

\section{$1^{\circ}$ Passo: Sensibilização}

Neste passo, realiza-se uma visita de sensibilização para apresentação da metodologia e etapas de implementação do programa para a Diretoria da cooperativa. Na sequência, a Diretoria da cooperativa tem o compromisso de apresentar a equipe técnica e gerencial que será responsável pelo andamento das etapas do programa.

\section{$2^{\circ}$ Passo: Avaliação e diagnóstico}

Nesta fase, realizam-se as atividades de diagnóstico e avaliação da Gestão de Qualidade na cooperativa, procurando checar qual é o perfil dos produtores (e seus respectivos sistemas produtivos), estrutura de veículos de coleta do leite e estrutura de refrigeração e armazenamento. Com isso, verifica-se qual é o perfil de resultados da CBT do leite nas fazendas, no transporte e silo. A partir dessas informações, definem-se os objetivos e metas de obtenção de resultados. No geral, o diagnóstico é realizado com até duas visitas na cooperativa.

Nesta fase, a cooperativa é orientada a analisar os resultados de qualidade dos produtores e realizar rotas ou sequencias de coleta conforme os resultados de CBT. Deste modo, evita-se que o leite com CBT elevada (maior que $100.000 \mathrm{UFC} / \mathrm{mL}$ ) misture com o leite de boa qualidade (menor que $100.000 \mathrm{UFC} / \mathrm{mL}$ ).

Com isso, a cooperativa tem três alternativas para segregar o leite:

- $\left.1^{a}\right)$ Enviar o leite segregado dos produtores com melhores resultados, direto para a recepção de leite Danone, sem passar pelo silo da cooperativa, conforme ilustrado na Figura 15; 
Figura 15 - Segregação do leite em rotas que vão direto para a Danone.

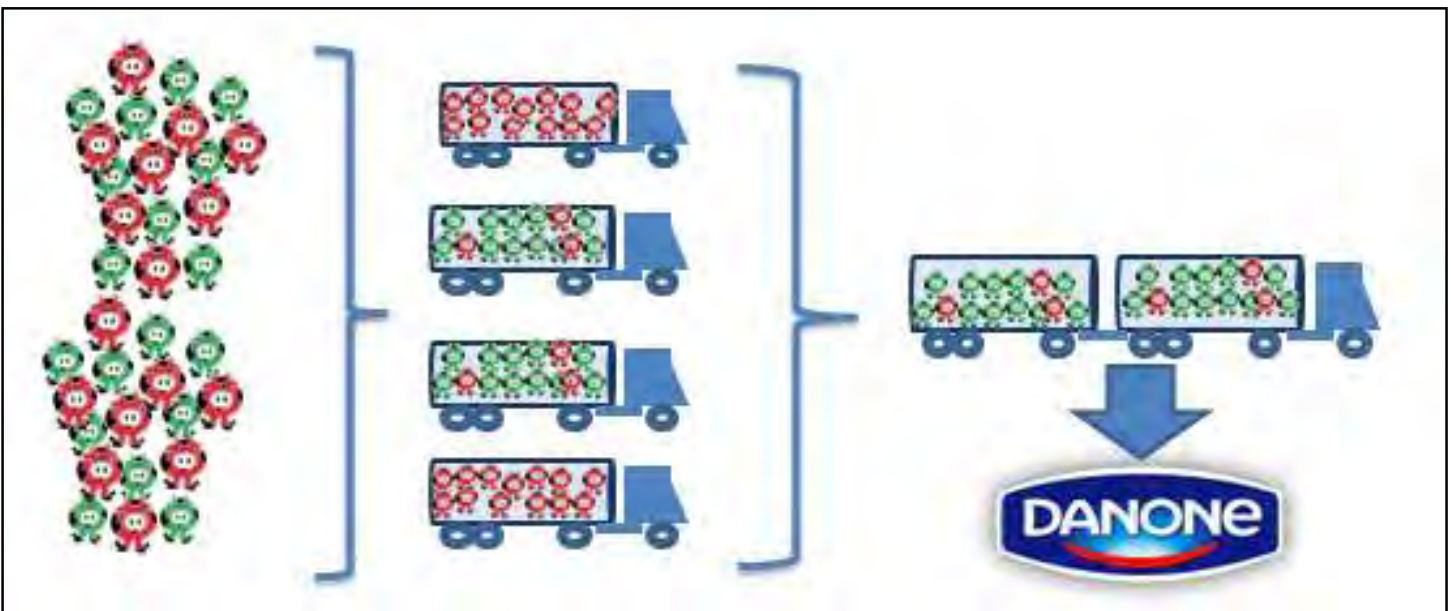

Fonte: Programa Qualileite Danone.

- $\left.\quad 2^{a}\right)$ Transvase de leite dos caminhões das rotas segregadas direto para o caminhão de envio para a Danone, passando somente pelo resfriador, sem armazenar no silo (Figura 16).

Figura 16 - Transferência do leite segregado para caminhões que vão direto para a Danone.

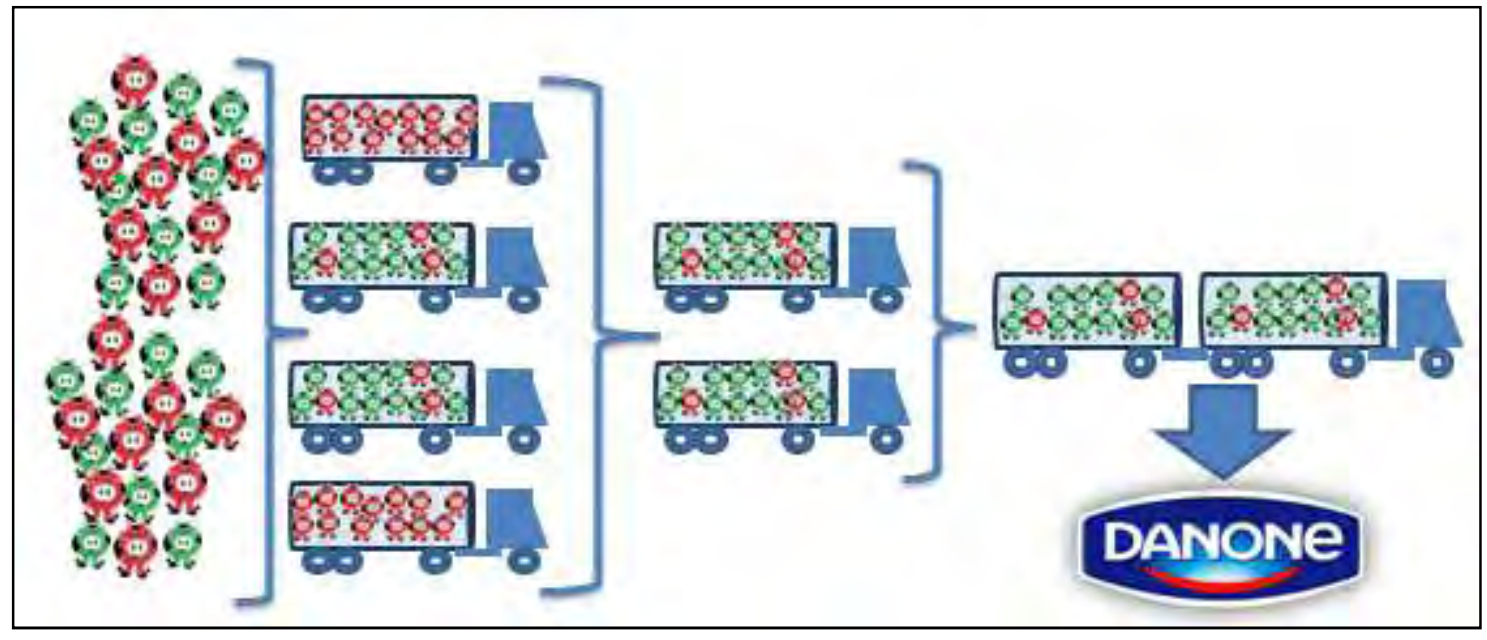

Fonte: Programa Qualileite Danone. 
- $3^{\mathrm{a})}$ Segregar as rotas num silo específico da cooperativa e carregar o caminhão para enviar o leite para a Danone (Figura 17);

Figura 17- Segregação do leite de rotas em silos específicos

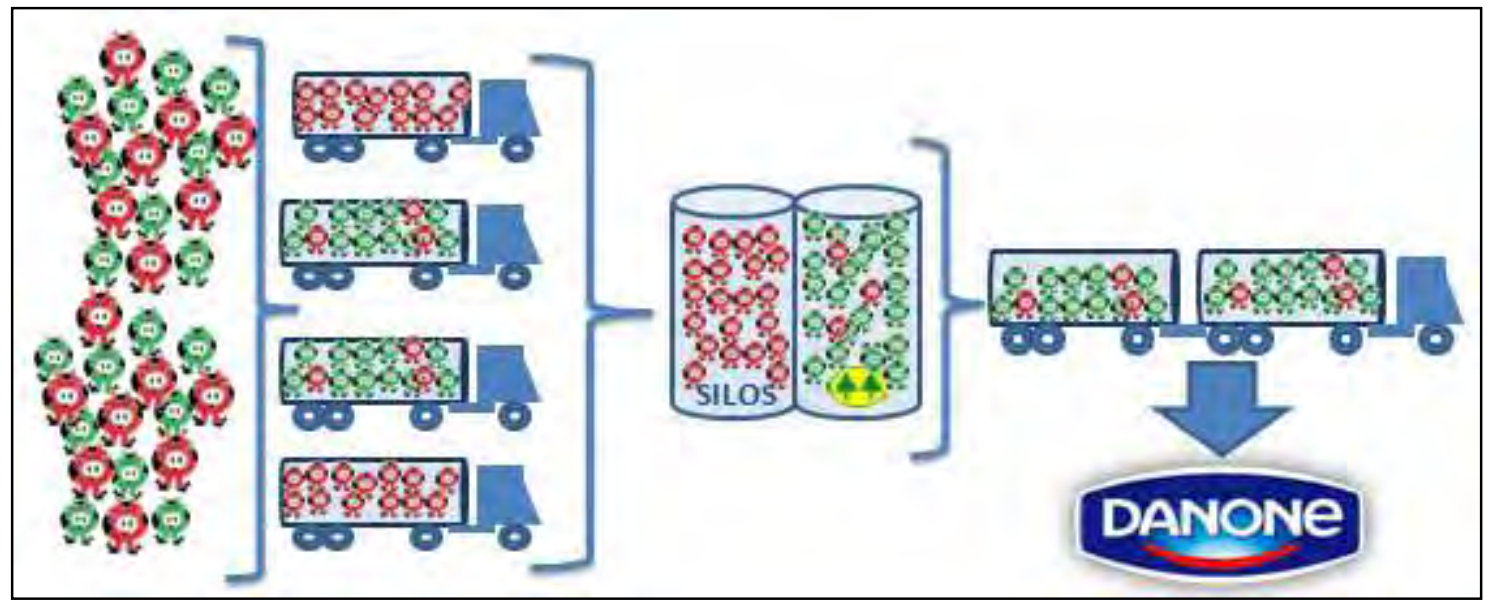

Fonte: Programa Qualileite Danone.

Por meio dessas alternativas de envio, o leite com qualidade superior não é misturado com o leite de qualidade inferior, havendo possibilidade de obter bons resultados da carga de leite na recepção Danone. É importante ressaltar que estas alternativas são ações paliativas, ou seja, são ações de curto prazo que trazem bons resultados e podem estimular a adoção de boas práticas aos demais produtores; no entanto, o objetivo central do programa é aplicar a gestão da qualidade do leite em toda a cadeia do leite da cooperativa a fim de obter $100 \%$ do volume dentro da especificação da IN 62.

\section{$3^{\circ}$ Passo: Definição do Planejamento.}

No $3^{\circ}$ passo define-se o planejamento através da implantação das ferramentas de gestão, plano de coletas de amostras e monitoramento de qualidade, plano de cursos e treinamentos de qualificação aos funcionários. Além disso, determinam-se os investimentos para todas as ações planejadas.

\section{$4^{\circ}$ Passo: Capacitação do time interno, transportadores e produtores.}

No $4^{\circ}$ passo, inicia-se a capacitação do time interno da cooperativa por meio do aperfeiçoamento dos controles gerenciais de dados e informações, delineamento de objetivos e metas e transferência de informações por meio de relatórios.

Neste caso, é proposta a utilização e adequação de um acompanhamento dos 
resultados dos produtores, utilizando-se a Curva $\mathrm{ABC}^{4}$, no qual constam os resultados das coletas mensais e relaciona-se com o volume de fornecimento diário de cada produtor. Deste modo encontra-se o perfil da qualidade dos produtores e têm-se uma visão dos produtores com qualidade fora do objetivo, os quais devem ser orientados pelo técnico de campo através de uma visita à propriedade. No mesmo sentido, é feita a compilação dos resultados dos compartimentos dos caminhões e o volume dos mesmos. Estes resultados mensais são tabulados numa planilha para acompanhar a evolução do ano e atingimento dos objetivos através de gráficos ilustrativos.

Uma das premissas do Qualileite é o pagamento diferenciado pela qualidade do leite à Cooperativa e, consequentemente, a cooperativa repassar este diferencial aos produtores, pois os mesmos devem ser incentivados financeiramente a atingir a qualidade almejada. No entanto, quando os parâmetros de qualidade não são atingidos, da mesma forma, cabe à cooperativa penalizar os produtores pela falta de qualidade do leite produzido. Portanto, é extremamente importante a implantação do sistema de pagamento pela qualidade do leite logo no início do programa para estimular a adesão dos produtores no atendimento dos objetivos da qualidade.

Ainda sobre a capacitação do time interno à cooperativa, um técnico de campo é treinado para fazer um check-list à campo, a fim de verificar as boas práticas de ordenha, qualidade da água, checagem estrutural da ordenhadeira, limpeza dos equipamentos, ambiente condições de sanidade dos animais. Neste check-list, o técnico faz um relatório final e passa orientações com um plano de ação ao produtor.

Um técnico da cooperativa também é treinado pelo programa Qualileite para checar as condições estruturais do caminhão tanque, as condições higiênicas do agente de coleta e os equipamentos de coleta de leite e de amostras. Aos transportadores de leite, é proposto um treinamento de boas práticas da coleta de leite e amostras de qualidade e rastreabilidade, análise de resultados e importância da segregação do leite.

Da mesma forma, o analista de laboratório da cooperativa é treinado para adequar-se a todas as metodologias e análises laboratoriais feitas na recepção de leite pelos técnicos da Danone. Além disso, este analista também é treinado para

\footnotetext{
${ }^{4}$ A Curva $A B C$ é uma ferramenta de refinamento da gestão que indicará quais são as prioridades de acordo com a representatividade do volume dos produtores. Maiores detalhes, já foram inseridos no capítulo anterior.
} 
aplicar ou aperfeiçoar as Boas Práticas de Fabricação e Análise de Perigos e Pontos Críticos de Controle do laticínio ou usina de captação e refrigeração de leite.

$\mathrm{Na}$ fase de capacitação, as cooperativas são orientadas pelo Qualileite a participarem do Programa Leite Legal. O Leite Legal é um programa do sistema CNA (Confederação da Agricultura e Pecuária do Brasil)/SENAR (Serviço Nacional de Aprendizagem Rural), em parceria com o SEBRAE (Serviço Brasileiro de Apoio a Micro e Pequenas Empresas), que cria possibilidades por meio de ações de formação profissional rural, para que os pequenos e médios produtores produzam leite de qualidade, atendendo aos padrões exigidos pela legislação, contribuindo para o desenvolvimento do setor. A capacitação teórica e prática têm 16 horas de carga horária e contemplam temas, como: fisiologia da glândula mamária; manejo de ordenha, higiene, controle de mastite e qualidade da água.

\section{$5^{\circ}$ Passo: Avaliação dos Indicadores}

No $5^{\circ}$ passo, avalia-se a CBT em todos os elos do caminho do leite, do produtor ao silo da empresa e ao chegar na Danone, para certificar-se que a gestão da qualidade da cadeia de produção está sendo efetiva. Ao final, verificam-se o atendimento das metas e o andamento das ações e objetivos planejados.

\section{$6^{\circ}$ Passo: Melhoria Continua:}

Cada processo tem um cronograma de atividades e a expectativa de resultados esperados. A partir dessa avaliação, são identificadas as melhorias necessárias.

Todas as etapas são registradas num relatório de visita do Qualileite constando a descrição das atividades desempenhadas, o cenário encontrado e os planos de ação.

\subsection{Análise quantitativa dos resultados}

Foram analisados os resultados de média geométrica trimestral da CBT dos produtores das cooperativas, conforme é orientado na IN 62. Além disso, na Danone houve uma coleta de amostra de leite de cada carga proveniente de cooperativas, a fim de avaliar a porcentagem do volume que chega com resultados de CBT menores que 300.000 UFC/mL. 
Tanto as Cooperativas participantes do programa quanto a Danone, analisaram o leite cru integral no Laboratório da Clinica do Leite (Escola Superior de Agricultura Luiz de Queiroz - Universidade de São Paulo), credenciado ao RBQL (Rede Brasileira de Laboratórios de Controle da Qualidade do Leite), cujas metodologias estão descritas a seguir (CASSOLI; MACHADO, 2006):

1) Determinação da composição do leite cru (gordura, proteína, lactose, sólidos totais) realizada através do equipamento Bentley 2000 que utiliza a metodologia de infravermelho.

2) Determinação da contagem de células somáticas presentes no leite cru (CCS) realizada através do equipamento Somacount 300 que utiliza a metodologia de citometria de fluxo.

3) Determinação da contagem bacteriana total do leite cru (CBT) realizada através do equipamento Bactocount que utiliza a metodologia de citometria de fluxo.

Através de frascos de plasticos $50 \mathrm{~mL}$ e conservadas em bronopol (2-bromo2nitro-1,3-propanodiol) na concentração de $8 \mathrm{mg}$ do ingrediente ativo para cada 40 $\mathrm{mL}$ de amostra para análise de CCS e Composição. Frascos de $50 \mathrm{~mL}$ conservados em $130 \mu \mathrm{L}$ de azidiol (efeito bacteriostático composto de azida sódica, cloranfenicol, etanol, citrato de sódio e azul de bromofenol) para análise de CBT (CASSOLI; MACHADO, 2006).

A metodologia de determinação da CBT, conforme já mencionado, é a citometria de fluxo. Nesta técnica são utilizados corantes fluorecentes específicos, como é o caso do brometo de etídio. O corante penetra na célula bacteriana e se liga ao RNA e DNA. Quando excitadas pelo laser, as células passam a emitir radiação em comprimento de onda $620 \mathrm{~nm}$ que é coletada pelo sistema óptico, transferida para o sistema de filtros e posteriormente transformada em impulso elétrico pelo sistema eletrônico. Os impulsos por sua vez, são transformados em números de bactérias e estes, relacionados ao volume de leite analisado. Os resultados emitidos por este equipamento são expressos em números de bactérias por $\mathrm{mL}$ de leite e representam a contagem individual de bactérias $(\mathrm{CBI})$. Entretanto, como os padrões legais máximos para CBT do leite são estabelecidos em UFC (unidades formadoras de Colônias), a CBI deve ser transformada em UFC através de uma equação (SANTOS; FONSECA, 2007) (CASSOLI, 2005). 


\subsection{Análise qualitativa do Qualileite}

Como mencionado anteriormente, a pesquisa descritiva abriga várias técnicas que procuram descrever e traduzir a questão principal, promovendo o entendimento do problema, no caso, como as diferentes cooperativas internalizam a dinâmica do Programa Qualileite e qual a efetividade dos resultados alcançados. Em outras palavras, pretende-se ter uma melhor compreensão dos erros e acertos do Programa Qualiteite nas diferentes cooperativas e, sobretudo, entender o que potencializa tais resultados.

Em virtude do escopo e objetivo do programa, o método qualitativo é mais direcionado à compreensão dos fatos do que à mensuração de fenômenos (YIN, 2005). A pesquisa qualitativa é adequada em estudos de assuntos complexos, permitindo que o pesquisador obtenha informações mais detalhadas e trabalhe com mais profundidade a questão a ser estudada. A maior vantagem deste tipo de pesquisa reside na riqueza dos detalhes obtidos.

Neste sentido, foi adotado o método de estudos multicasos, sendo que cada cooperativa analisada compõe um caso específico, cujas variáveis a serem analisadas são comuns aos casos. De acordo YIN (2001), os estudos multicasos são caracterizados pelo maior foco na compreensão e na comparação qualitativa dos fenômenos, além de proporcionar uma maior abrangência dos resultados, não se limitando às informações de uma só organização.

Os casos abordados foram retratados por meio de entrevistas semiestruturadas com representantes das cooperativas participantes do programa, conforme modelo descrito a seguir:

1) O programa trouxe facilidades e conhecimentos para a rotina operacional e técnica cooperativa?

2) Quais foram as ferramentas e treinamentos mais importantes para a melhoria no desempenho das atividades?

3) Houve melhoria nos indicadores da qualidade do leite da cooperativa?

4) Houve melhoria na remuneração por qualidade do leite vendido para a Danone?

5) Qual foi a aceitação dos funcionários quanto à mudança de procedimentos: Pagamento pela qualidade, Check-list de campo, check- 
list de caminhão, aumento de amostragem, adequação das análises de recepção de leite e treinamentos?

6) Qual foi a aceitação dos produtores quanto ao pagamento pela qualidade do leite, treinamento leite legal e aplicação do check-list de campo pelo técnico da cooperativa?

7) Qual foi a aceitação dos motoristas quanto aos procedimentos de higiene na coleta e treinamento de agente de coleta de leite?

8) Qual é sua avaliação de 0 a 10 para o Qualileite da Danone?

9) Você recomendaria este programa para outra cooperativa?

Para tanto, foram conduzidas 4 (quatro) entrevistas semi-estruturadas com os responsáveis pela condução do programa nas cooperativas (diretor, técnico, etc), realizadas no período compreendido entre 01/03/2016 à 30/04/2016.

\section{RESULTADOS}

Os resultados aqui apresentados são relativos às diferentes abordagens metodológicas adotadas para a avaliação do Programa Qualileite. Por este motivo, optou-se por desdobrar a análise dos resultados em duas frentes distintas, porém complementares: uma frente de análises quantitativas - que demonstram os resultados objetivos da qualidade do leite com o a adoção do Qualileite, e outra frente de análises qualitativas - que relatam as percepções dos gestores das cooperativas, com a implantação do programa e os impactos aos produtores cooperados.

\subsection{Resultados Quantitativos}

Desde o início da implantação do programa e, sobretudo, devido às ações de curto prazo (segregação do leite de melhor qualidade ao leite de qualidade inferior), a Danone tem recebido leite de melhor qualidade das cooperativas participantes do Qualileite. Após a aplicação de todas as capacitações técnicas, ferramentas da gestão da qualidade planejadas e efetivação das ações estabelecidas, o programa apresentou evolução de resultados, com melhorias consistentes na qualidade do leite recebido das cooperativas participantes. 
Este fato é claramente exposto na Figura 18, a qual mostra a diferença significativa da qualidade do leite do programa Qualileite versus o volume do leite de outros fornecedores não participantes do Qualileite, ou seja, a média do volume de leite com CBT menor que 300.000 UFC/mL no Qualileite em 2014 foi 40\%, enquanto as cooperativas não participantes do Qualileite somaram apenas 3\%. Em 2015 este comparativo apresentou média de 55\% no Programa Qualileite e apenas 3\% nas demais cooperativas, conforme Figura 19. Este resultado comprova a eficiência do programa e mostra que há oportunidades para que as empresas invistam em ações que tragam melhorias na qualidade e obtenham melhores resultados.

Figura 18 -\% do volume de leite provido de cooperativas na recepção Danone com CBT $<300.000$ UFC/mL em 2014.

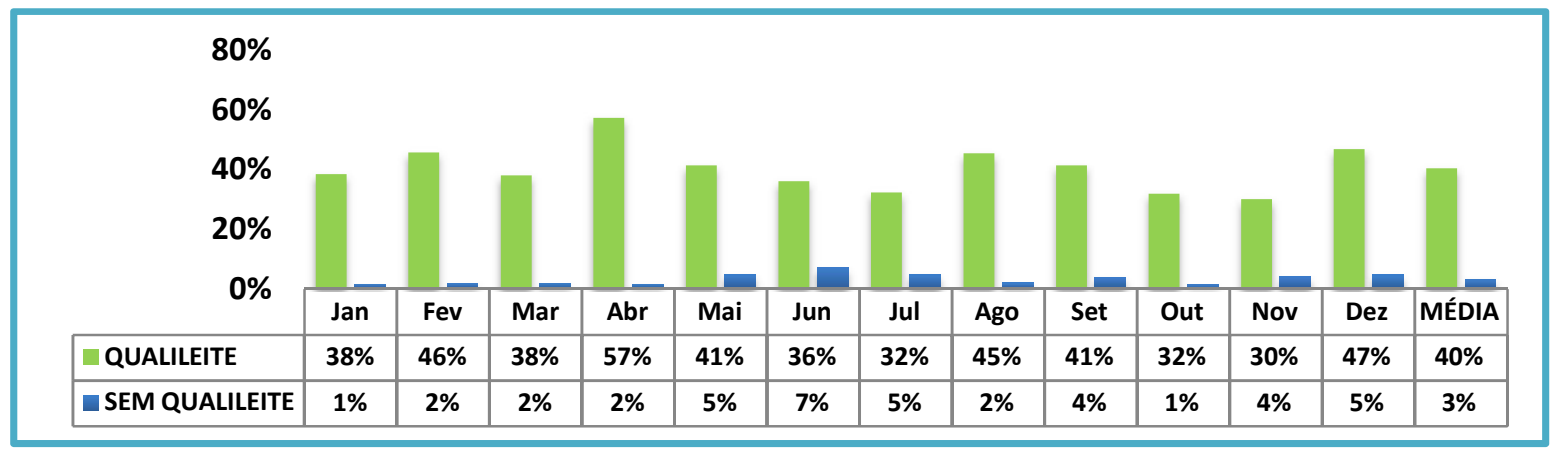

Fonte: Programa Qualileite Danone.

Figura 19 - \% do volume de leite provido de cooperativas na recepção Danone com CBT $<300.000$ UFC/mL em 2015.

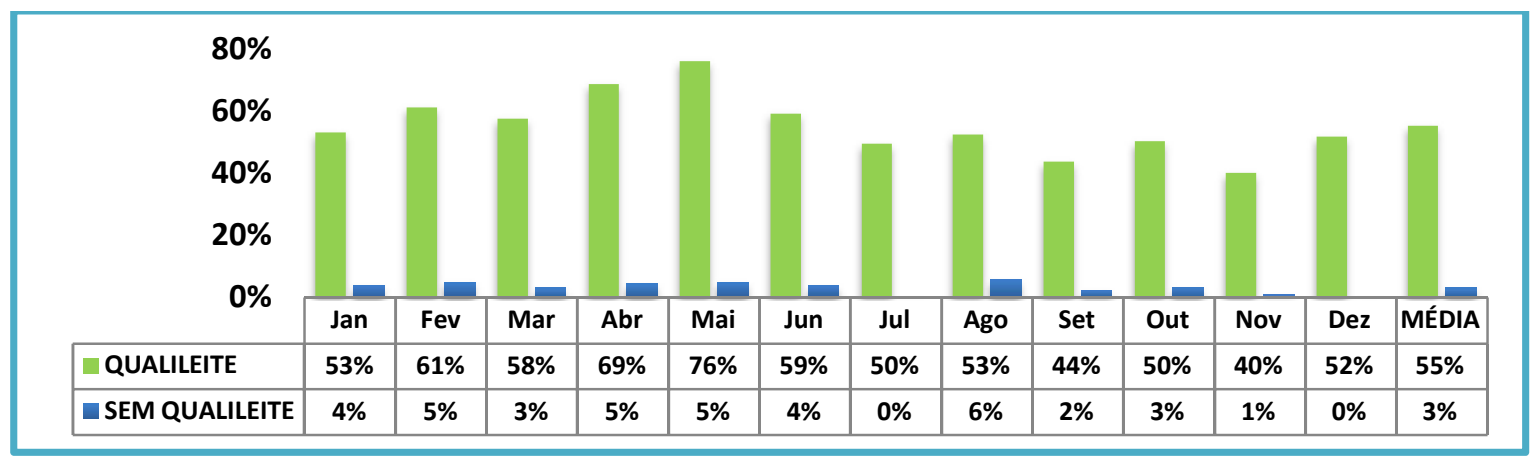

Fonte: Programa Qualileite Danone. 


\subsubsection{Análises quantitativas por cooperativa}

A seguir serão apresentadas as análises quantitativas por cooperativa desde os resultados de produtores até os resultados encontrados na recepção do leite Danone.

\section{a) CORPLES}

i) Cooperados

Os cooperados da Corples apresentaram média geométrica trimestral de CBT, conforme descrito a seguir:

- Em 2012: 217.000 UFC/mL; Grupo estatístico A;

- Em 2013: 238.000 UFC/mL; Grupo estatístico A;

- Em 2014: 234.000 UFC/mL; Grupo estatístico A;

- Em 2015: 234.000 UFC/mL; Grupo estatístico A.

Ao analisar os dados mensais de CBT no período de 2012 a 2015 no método estatístico de Tukey a um nível de significância de 5\%, não rejeitamos a hipótese de igualdade entre as médias anuais encontradas, ou seja, as médias não diferem significativamente.

A Figura 20 apresenta os resultados dos produtores da Corples desde 2012 e apresenta uma linha de tendência descendente. Entretanto, no final de 2013 houve um pico de $433.000 \mathrm{UFC} / \mathrm{mL}$, coincidindo com a saída do técnico de campo em setembro de 2013 e a consequente elevação de CBT nas propriedades leiteiras, as quais as visitas no campo foram retomadas em janeiro de 2014 pelo técnico substituto e a CBT foi regularizada em fevereiro de 2014 com a média de 264.000 UFC/mL. 
Figura 20 - Média Geométrica Trimestral CBT Produtores Corples

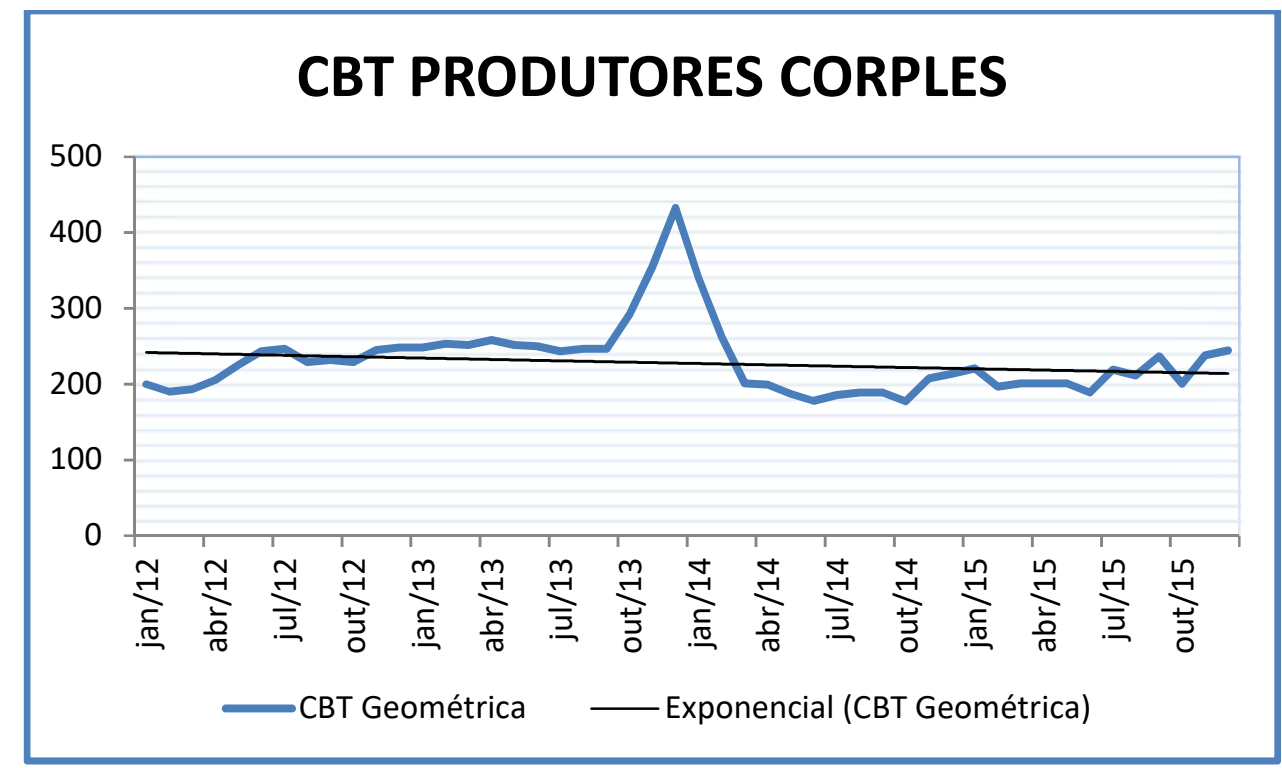

Fonte: Programa Qualileite Danone.

Com isso, pode-se afirmar que em 2015 a Corples atendeu aos limites atuais de CBT da IN 62 (menor que $300.000 \mathrm{UFC} / \mathrm{mL}$ ), entretanto, para atender aos limites desta normativa a partir de julho de 2018 (que será menor que 100.000 UFC/mL), precisará intensificar ainda mais os trabalhos a campo.

ii) Cooperativa

Ao analisar os resultados da Corples na recepção de Leite da Danone, é possível verificar a melhoria imediata com o início do Qualileite em Junho de 2012, conforme exposto na Figura 21. Isso graças ao reflexo das ações de curto prazo do Qualileite, como por exemplo, a segregação do leite mencionada anteriormente. 
Figura 21 - Indicador CBT Corples em 2012 com o início do Qualileite em junho.

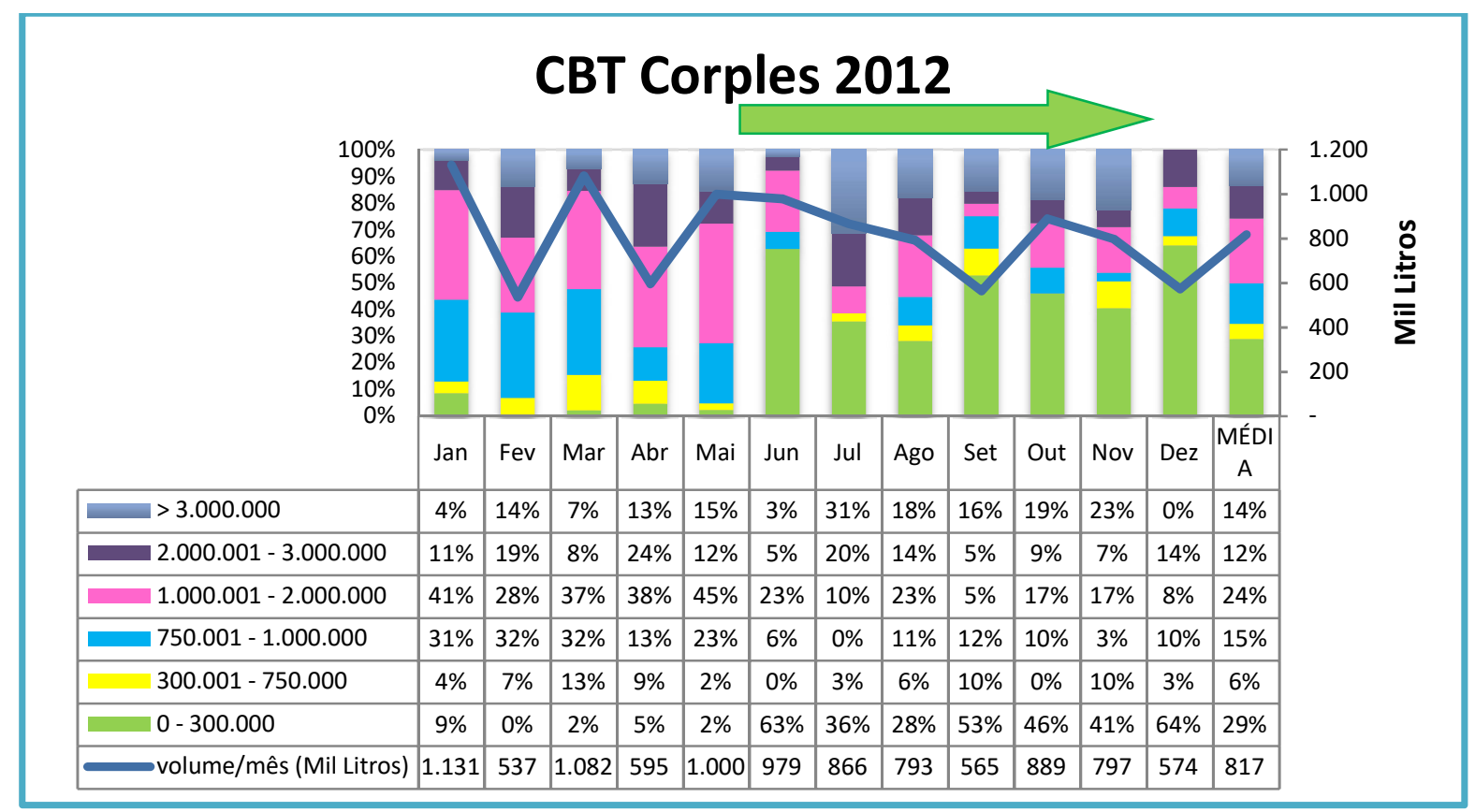

Fonte: Programa Qualileite Danone.

Com isso, verifica-se na Figura 22 que cooperativa de Serrania (Corples) aumentou o volume com CBT abaixo de 300.000 UFC/mL de 2012 para 2013 em 26 pontos percentuais, ou seja, 29\% em 2012 evoluindo para 55\% em 2013. Entretanto com a evolução de volume entregue de 574.000 litros/mês em 2013 para 939000 litros/mês em 2014 o volume com resultados abaixo de 300.000 UFC/mL reduziu para 40\%, mas recuperou em 2015 com 62\%. 
Figura 22 - Indicador CBT Corples de 2012 a abril de 2016 na recepção de leite Danone.

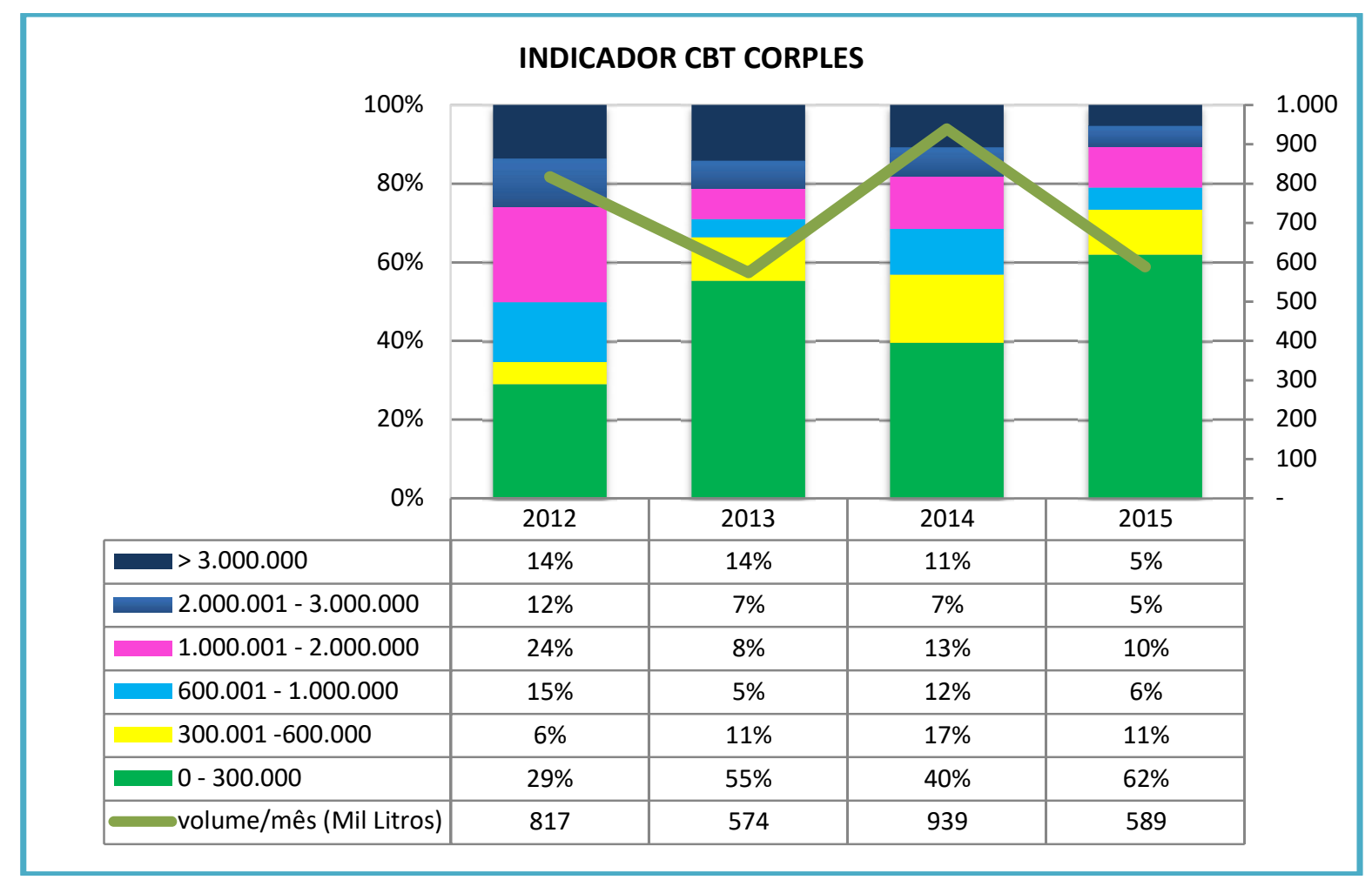

Fonte: Programa Qualileite Danone.

Isto ocorreu devido ao volume excedente não possuir qualidade, com isso a cooperativa iniciou o trabalho de desenvolvimento da qualidade do leite dos produtores para assim obter melhorias gradativas. Conforme já mencionado, esta cooperativa possui $27 \%$ do volume de leite provido de tanques comunitários, ou seja, encontra-se até 30 produtores compartilhando um tanque de até dois mil litros. Por se tratar de diversos produtores num mesmo tanque, os trabalhos de melhoria da qualidade são mais onerosos e demandam maiores atenções e perseverança da equipe técnica da cooperativa.

Durante os 6 primeiros meses do programa, mediu-se a quantidade de cumprimento de ações em relação às ações propostas às 3 cooperativas. De 32 ações propostas à Corples, apenas 3 não foram cumpridas, ou seja, $10 \%$ do total.

A primeira ação não cumprida foi a solicitação de coletar 8 amostras de produtor e rota durante 2 meses, sendo que a cooperativa coletava apenas 2 amostras/mês. Esta ação foi solicitada para refinar o diagnóstico e entender melhor o perfil de cada produtor, podendo encontrar oscilações de resultados de um mesmo produtor num 
período de 60 dias. Entretanto, devido ao custo, esta ação não foi cumprida, e com isso, o diagnóstico foi analisado através das 2 amostras mensais praticadas pela cooperativa. Fator que não prejudicou o andamento do programa.

A segunda ação não cumprida foi a não realização de um evento de sensibilização, ressaltando a importância da qualidade do leite e capacitação aos produtores. Esta ação é muito importante para incentivar e capacitar os cooperados, principalmente devido ao grande volume provido de tanques comunitários e com pouco conhecimento em boas práticas de higiene na ordenha. Portanto, esta é uma ação que certamente reflete impacto positivo nos resultados.

\section{b) COOPAS}

i) Cooperados

Os cooperados da Coopas apresentaram média geométrica trimestral de CBT, conforme descrito a seguir:

- Em 2012: 135.000 UFC/mL; Grupo estatístico A;

- Em 2013: 153.000 UFC/mL; Grupo estatístico A B;

- Em 2014: 83.000 UFC/mL; Grupo estatístico B C;

- Em 2015: 53.000 UFC/mL; Grupo estatístico C.

Ao analisar os dados mensais de CBT no período de 2012 a 2015 no método estatístico de Tukey a um nível de significância de 5\%, as médias de 2012 - 2013, 2013 - 2014 e 2014 - 2015 são iguais. As médias 2012 - 2014, 2012 - 2015 e 2013 2015 apresentam diferenças significativas.

Em 2013 antes do início do programa, a média foi de 153.000 UFC/mL, já em 2015, com dois anos de andamento do programa, a média foi de $53.000 \mathrm{UFC/mL}$, melhorando $34 \%$ a média de CBT em relação ao ano que antecedeu o início do programa.

Conforme a Figura 23, os resultados apresentam uma linha de tendência decrescente e atendem ao limite de CBT atual (menor que $300.000 \mathrm{UFC} / \mathrm{mL}$ ) e se mantiver o padrão de controle e resultados, estará dentro das exigências da IN 62 em 2018. 
Figura 23 - Média Geométrica Trimestral CBT Produtores Coopas

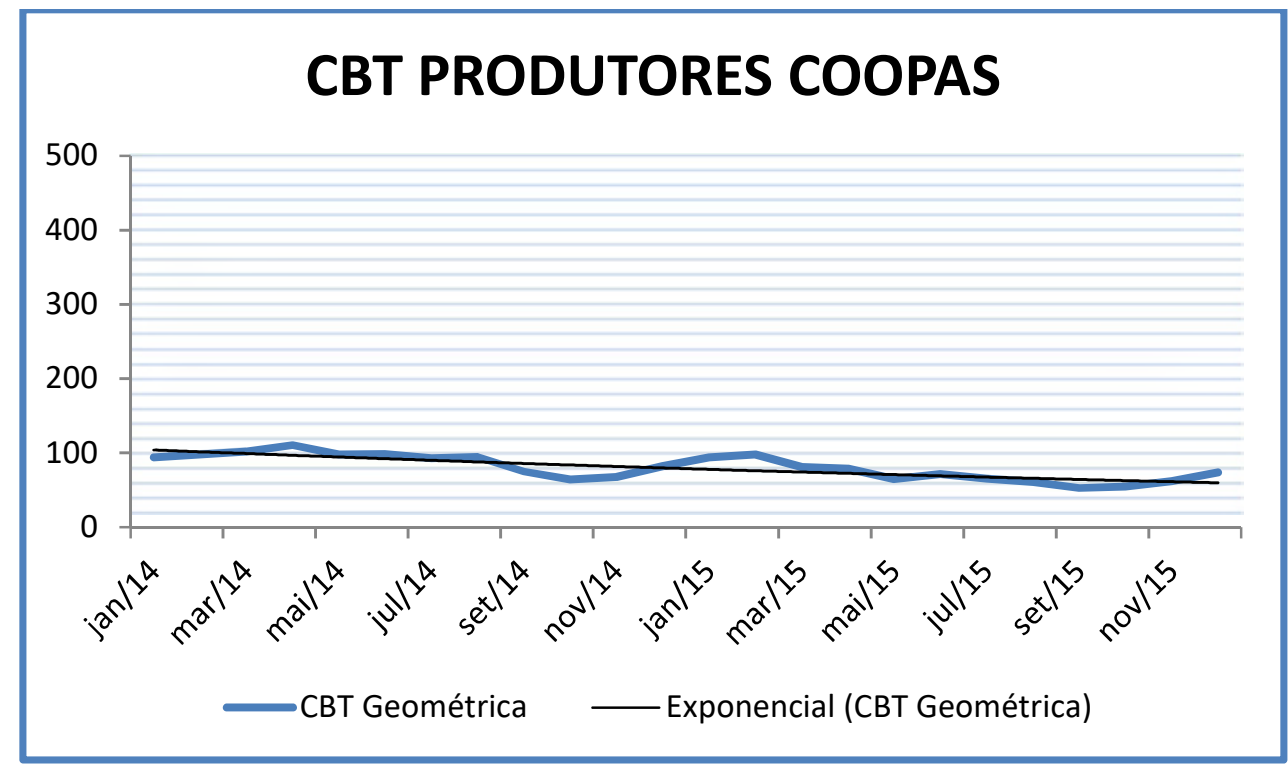

Fonte: Programa Qualileite Danone.

\section{ii) Cooperativa}

A Cooperativa de Santa Rita de Caldas (Coopas), no qual iniciou as atividades do Qualileite em junho de 2014, apresentou bons resultados na média deste ano saindo de $15 \%$ (<300.000 UFC/mL) em 2013 atingindo 42\% em 2014 e 46\% em 2015 (Figura 24). 
Figura 24 - Indicador CBT COOPAS de 2012 a 2015 na recepção de leite Danone.

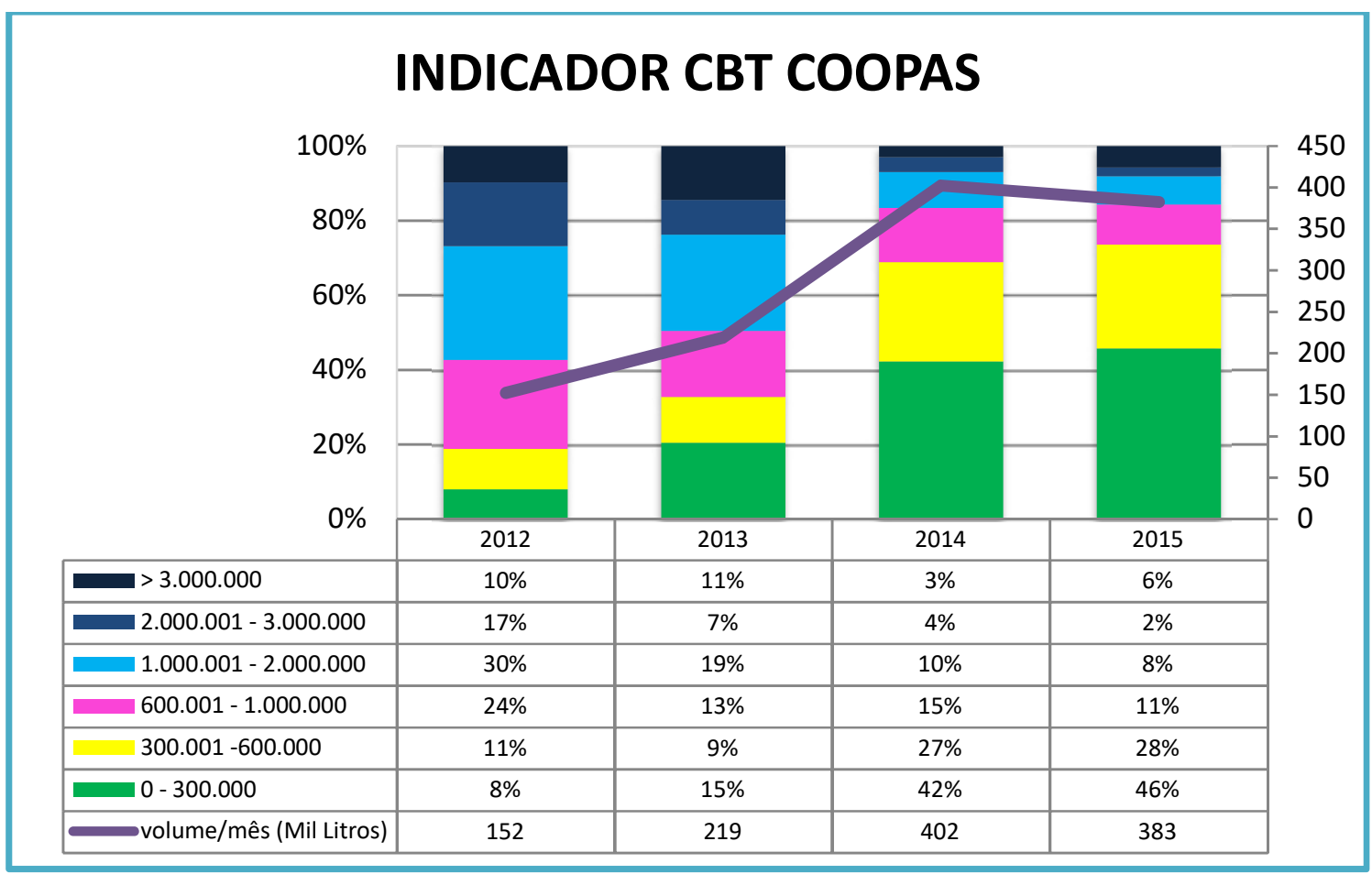

Fonte: Programa Qualileite Danone.

Em 2014 apesar de a média ter sido 42\%, em outubro e novembro com o início do período chuvoso, foram identificados produtores com resultados fora do objetivo (100.000 UFC/mL) na curva abc, os quais foram visitados e orientados retomando para $41 \%$ em dezembro (Figura 25). É importante ressaltar que 100\% do volume são de produtores de tanque individual, fator que otimiza o trabalho do técnico no campo, possibilitando obtenção de resultados mais rápidos. 
Figura 25 -Indicador CBT Coopas em 2014 com o início do Qualileite em junho.

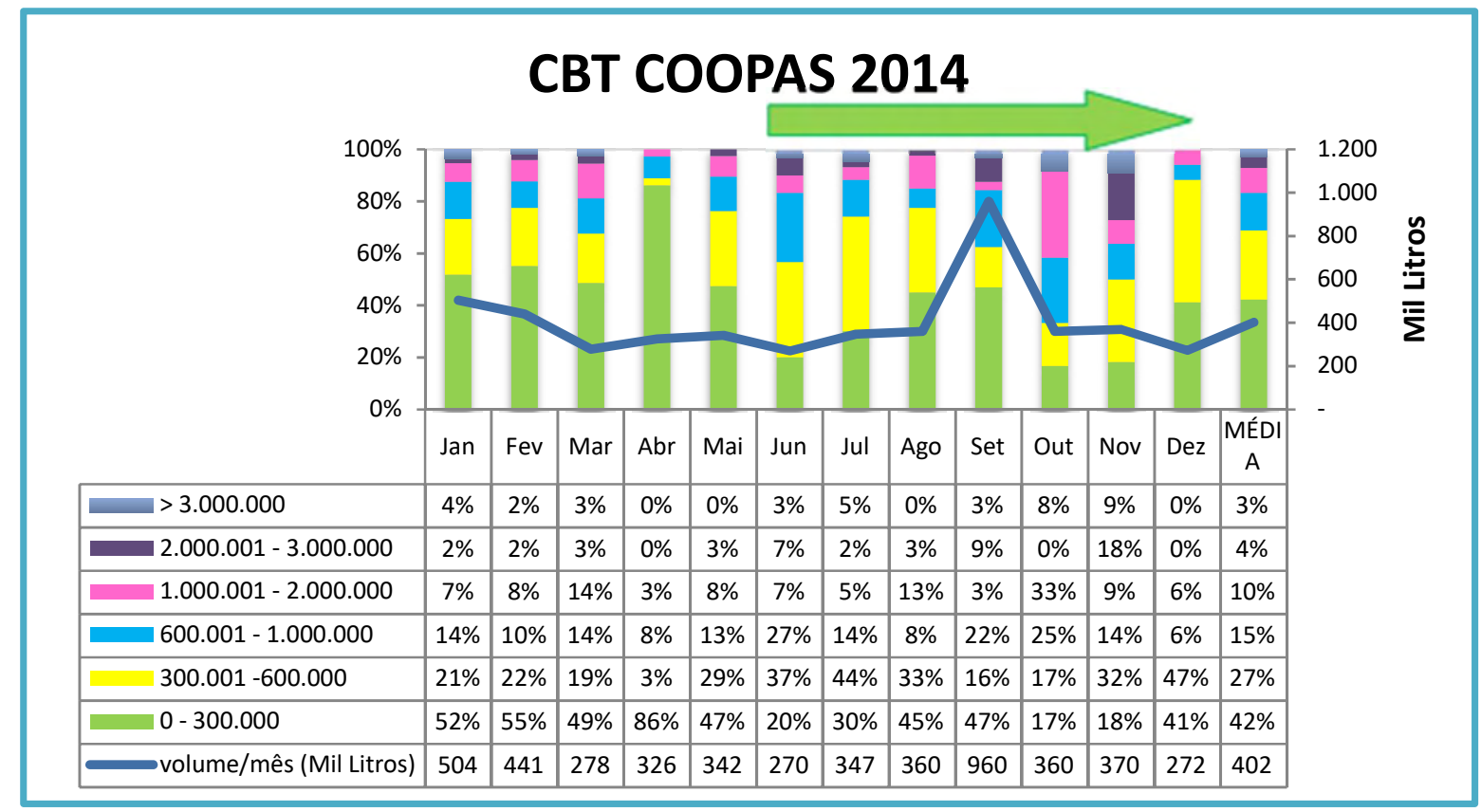

Fonte: Programa Qualileite Danone.

No que diz respeito às ações não cumpridas nos 6 primeiros meses do programa, a cooperativa deixou de cumprir 6 de 17 propostas, ou seja, 35\%. Neste período, a cooperativa estava estruturando o setor de qualidade do leite, houve troca de funcionários o que atrasou o cumprimento das ações.

A cooperativa atrasou em formar um grupo de 15 produtores para participarem do Programa Leite Legal; realização de verificação dos caminhões-tanque e plano de ação diante de não conformidades; Apresentação dos relatórios de visita de campo; coletas de amostra de silo para avaliar a eficiência da segregação do leite. Entretanto, após a formação do setor de qualidade e treinamento dos funcionários em 2015, a cooperativa evoluiu no cumprimento das ações.

c) "COOPERATIVAX"

i) Cooperados

Os cooperados da "Cooperativa X" apresentaram média geométrica trimestral de CBT, conforme descrito a seguir:

- Em 2012: 272.000 UFC/mL; Grupo estatístico B;

- Em 2013: 358.000 UFC/mL; Grupo estatístico A;

- Em 2014: 278.000 UFC/mL; Grupo estatístico A B; 
- Em 2015: 193.000 UFC/mL; Grupo estatístico C.

Ao analisar os dados mensais de CBT no período de 2012 a 2015 no método estatístico de Tukey a um nível de significância de 5\%, as médias de 2013 - 2014 e 2012 - 2014 são iguais. As médias 2012 - 2013, 2012 - 2015, 2013 - 2015 e 2014 2015 apresentam diferenças significativas.

Os resultados de CBT média geométrica trimestral em 2014 e 2015 foram 278.000 UFC/mL e 193.000 UFC/mL respectivamente, ou seja, obteve redução de $31 \%$.

A Figura 26 apresenta os resultados de média geométrica trimestral dos cooperados e de acordo com estes dados, pode-se afirmar que em 2015 esta cooperativa atendeu aos limites da IN 62 (menor que 300.000 UFC/mL), porém para o aumento do rigor que entrará em vigor em 2018 (menor que 100.000 UFC/mL), a cooperativa terá que intensificar os trabalhos a campo, reduzindo a média geométrica de seus produtores.

Figura 26 - Média Geométrica Trimestral CBT Produtores Cooperativa X"

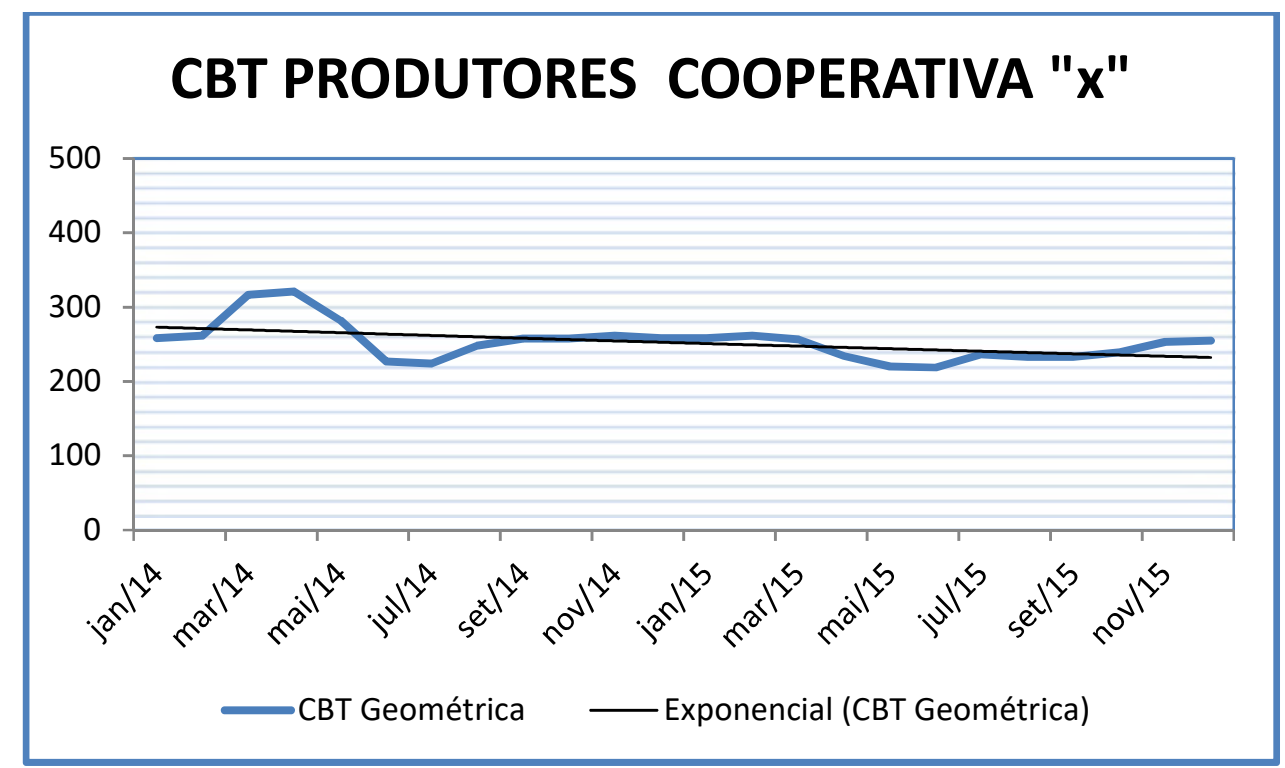

Fonte: Programa Qualileite Danone.

ii) Cooperativa

A cooperativa "X" iniciou o Qualileite em março de 2014, mas tevê o trabalho interrompido em novembro de 2014 , pois não atendeu a $44 \%$ dos requisitos e 
cumprimento de ações estabelecidas pelo programa e com isso, não renovou o contrato de fornecimento. Consequentemente, não houve evolução nos resultados, ou seja, apenas $9 \%$ do volume com resultados de CBT $<300.000$ UFC/mL (Figura 27).

Figura 27 - Indicador CBT Cooperativa "X” 2014, com início do Qualileite em março. e interrupção em novembro.

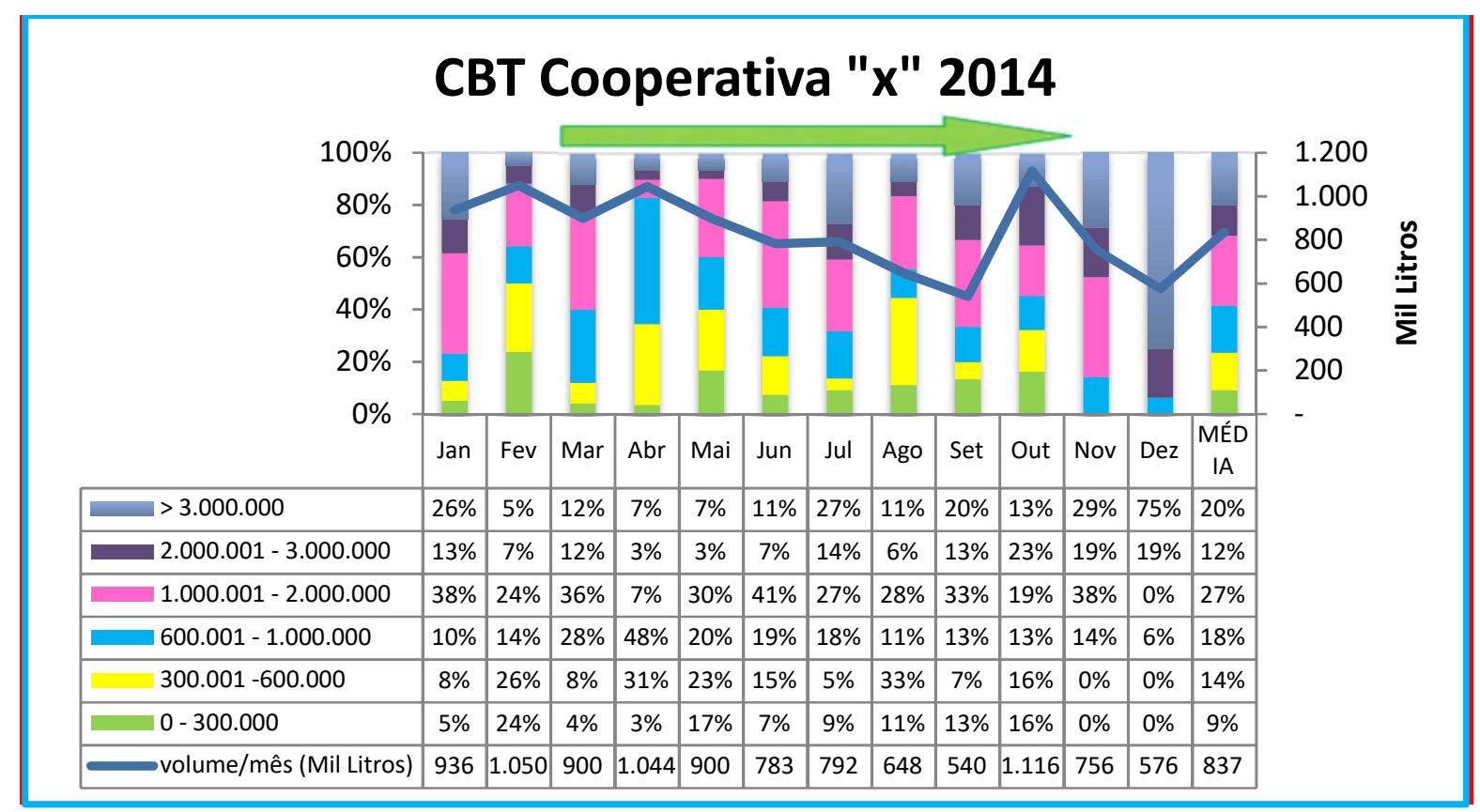

Fonte: Programa Qualileite Danone.

Entre as ações não cumpridas, destacam-se o não pagamento pela qualidade do leite dos cooperados, as condições estruturais dos caminhões tanque estavam precárias, os mesmos não eram lavados externamente antes de descarrega-los e houve relatos de funcionários a parte interna do tanque não era lavada antes de realizar a segunda rota de coleta do leite do dia. Além disso, a cooperativa foi convidada a participar de um treinamento oferecido pela Danone de APPCC (Análise de Perigos e Pontos Críticos de Controle), entretanto não compareceu. Com isso, as visitas dependiam de uma evolução no cumprimento das ações propostas para que pudéssemos progredir no cronograma do programa, caso que não ocorreu e o mesmo foi suspenso. 


\subsubsection{Análise quantitativa entre as cooperativas}

A Coopas obteve melhor resultado em 2015 (53.000 UFC/mL), pois além de ter tido um bom desempenho no Qualileite, possui menor número de cooperados (220) em relação às demais cooperativas (Corples 309 produtores com CBT em 2015 234.000 UFC/mL e "Cooperativa X" 540 produtores e CBT 2015193.000 UFC/mL) considerando que todas as cooperativas do programa dispõem de apenas um técnico de campo independente do número de produtores, ou seja, quanto menos produtores, melhor será a abrangência do atendimento a campo. Além disso, 100\% dos cooperados da Coopas possuem tanque refrigerado individual, fator que facilita 0 trabalho no campo, obtendo respostas mais rápidas.

Por outro lado, a Corples e a Cooperatixa "X" possuem $27 \%$ e 15\% do volume de leite de tanques comunitários respectivamente, fator que demanda maiores cuidados de controle e intensifica o trabalho dos técnicos no campo. Outra desvantagem da Corples em relação à Coopas e Cooperativa "X" é o tempo médio das rotas para coletar o leite, o qual a Corples leva 8 horas enquanto as demais levam 5 horas, ou seja, maior tempo de permanência do leite no tanque do caminhão durante o transporte, podendo prejudicar a qualidade do leite devido à multiplicação das bactérias psicotróficas.

Um interessante indicador é a porcentagem de ações de curto prazo não cumpridas diante das estabelecidas nos primeiros seis meses de atuação do programa em ambas as cooperativas. Conforme exposto na Figura 28, nota-se que a cooperativa de Serrania (Corples) tevê menor porcentagem de ações não cumpridas em relação à cooperativa de Santa Rita de Caldas (Coopas), ou seja, 10\% contra 35\% respectivamente. Ao comparar com os resultados iniciais de ambas as cooperativas, verifica-se maior estabilidade na Corples após o início do Qualileite (Figura 21 exposta anteriormente), devido à agilidade no cumprimento das ações estabelecidas pelo programa, enquanto a Coopas tem maiores oscilações nos resultados de qualidade ao longo de 2014 (Figura 25 exposta anteriormente). 
Figura 28 - Porcentagem de ações não cumpridas diante das estabelecidas nos primeiros seis meses do programa

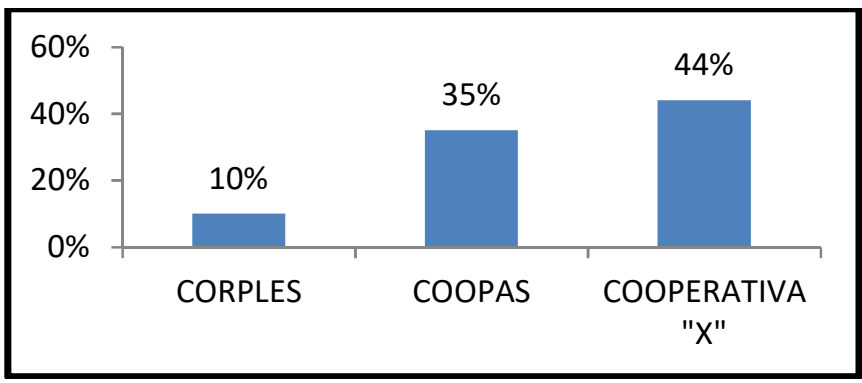

Fonte: Programa Qualileite Danone. 
Para melhor acompanhamento das cooperativas do programa e tomadas de decisões quanto às falhas e atrasos no cronograma do programa, um check-list foi desenvolvido e esta exposto no Quadro 3. Deste modo, além do andamento das ações, visualiza-se o check-list do Qualileite e verifica se as cooperativas estão evoluindo conforme o planejado. Caso a empresa não esteja cumprindo as ações e não tenha evolução nos resultados, o bônus de incentivo ao Qualileite oferecido pela Danone é suspenso. Não havendo reação da cooperativa, o contrato e o programa são interrompidos. Este foi o caso ocorrido com a Cooperativa "X", na qual apresentou diversas não conformidades no check-list e deixou de cumprir $44 \%$ das ações propostas no início do programa.

Quadro 3 - Check-List de ações e passos do Qualileite.

\begin{tabular}{|c|c|c|c|c|}
\hline & & CORPLES & COOPAS & COOPERATIVA $X$ \\
\hline \multirow{5}{*}{$\begin{array}{l}\text { ESTRUTURA } \\
\text { BÁSICA }\end{array}$} & TÉCNICO DE CAMPO & (:) & (;) & (:) \\
\hline & ANALISTA DE RESULTADOS & (;) & (:) & (;) \\
\hline & MÍNIMO 3 ANÁLISES/MÊS PRODUTOR; CAMINHÃO & (:) & (:) & (-) \\
\hline & PAGAMENTO PELA QUALIDADE DO LEITE & (:) & (-) & (2) \\
\hline & RECURSOS TECNOLÓGICOS & (:) & (:) & (:) \\
\hline INTEGRAÇÃO & $\begin{array}{l}\text { DANONE (DEPARTAMENTO DE } \\
\text { APROVISIONAMENTO LEITE E LABORATÓRIO } \\
\text { RECEPÇÃO DO LEITE) }\end{array}$ & (:) & (:) & (:) \\
\hline DIAGNÓSTICO & $\begin{array}{l}\text { PERFIL DOS PRODUTORES; LOGISTICO; } \\
\text { PLATAFORMA; ARMAZENAMENTO. }\end{array}$ & (:) & (:) & (:) \\
\hline \multicolumn{2}{|r|}{ SEGREGAÇÃO } & (:) & (:) & (:) \\
\hline & & & & \\
\hline \multirow{3}{*}{ PLANEJAMENTO } & PRODUTORES & (:) & (:) & (:) \\
\hline & TRANSPORTADORES & (i) & (:) & (-) \\
\hline & INTERNO & (-) & (-) & (2) \\
\hline \multirow{5}{*}{ CAPACITAÇÃO } & TREINAMENTO PRÁTICO TÉCNICO CAMPO & (:) & (;) & (2) \\
\hline & PROGRAMA LEITE LEGAL & (;) & (:) & (:) \\
\hline & TREINAMENTO CHECK-LIST CAMINHÃO & (:) & (:) & (:) \\
\hline & TREINAMENTO APPCC E BPF & (:) & (:) & (2) \\
\hline & FERRAMENTAS DE GESTÃO & (-); & (-) & (2) \\
\hline & 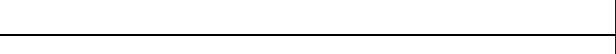 & & & \\
\hline \multirow{4}{*}{ VERIFICAÇÃO } & ATINGIMENTO DOS OBJETIVOS & (:) & (:) & (2) \\
\hline & CUMPRIMENTO DAS AÇÕES & (-) & (-) & (2) \\
\hline & TREINAMENTO CHECK-LIST CAMINHÃO & (;) & (;) & (2) \\
\hline & MELHORIA CONTÍNUA: NOVAS AÇÕES CICLO PDCA & (-); & (:) & (2) \\
\hline
\end{tabular}

Fonte: Programa Qualileite 


\subsection{Análises Qualitativas}

\section{A análise qualitativa consistiu em ouvir os responsáveis pelas cooperativas} envolvidas no programa, com o intuito de colher percepções sobre os impactos positivos e negativos - que o Qualileite proporcionou às cooperativas e cooperados, bem como, levantar possíveis pontos de melhoria do programa.

O Quadro 4 sintetiza algumas das percepções obtidas quanto à adesão do Qualileite nas cooperativas:

Quadro 4: Respostas das cooperativas ao questionário de avaliação do programa. Continua.

\begin{tabular}{|c|c|c|c|}
\hline Perguntas & CORPLES & COOPAS & COOPERATIVA $X$ \\
\hline $\begin{array}{l}\text { 1) O programa trouxe facilidades e } \\
\text { conhecimentos para a rotina operacional e } \\
\text { técnica cooperativa? Padrão de resposta: } \\
\text { SIM/NÃO/EM PARTES. }\end{array}$ & SIM & SIM & $\begin{array}{l}\text { Em partes, pois não foi } \\
\text { totalmente implantado. }\end{array}$ \\
\hline $\begin{array}{l}\text { 2) Quais foram as ferramentas e } \\
\text { treinamentos mais importantes para a } \\
\text { melhoria no desempenho das atividades? }\end{array}$ & $\begin{array}{l}\text { A troca de } \\
\text { conhecimentos foi uma } \\
\text { das mais importantes: } \\
\text { Conhecimentos técnicos } \\
\text { para melhoria da } \\
\text { qualidade microbiológica } \\
\text { do leite. Conhecimentos } \\
\text { na gestão da qualidade } \\
\text { utilizando o excel. }\end{array}$ & $\begin{array}{l}\text { Check list elaborados, } \\
\text { treinamento com a clinica do } \\
\text { leite e QCONZ, pagamento por } \\
\text { qualidade. }\end{array}$ & $\begin{array}{l}\text { Estamos realizando visitas } \\
\text { aos produtores não } \\
\text { conforme. }\end{array}$ \\
\hline $\begin{array}{l}\text { 3) Houve melhoria nos indicadores da } \\
\text { qualidade do leite da cooperativa? Padrão } \\
\text { de resposta: SIM/NÃO/EM PARTES. }\end{array}$ & $\begin{array}{l}\text { Sim com as constantes } \\
\text { visitas e pagamento por } \\
\text { qualidade por parte da } \\
\text { Danone tivemos que } \\
\text { fazer constantes visitas } \\
\text { nos produtores para que } \\
\text { eles se adequassem ao } \\
\text { padrão de qualidade } \\
\text { exigido. Houve melhora } \\
\text { na análise de CBT }\end{array}$ & $\begin{array}{l}\text { Sim, houve melhora de volume } \\
\text { chegando na Cooperativa sendo a } \\
\text { média do ano de } 2015 \text { de } 70 \% \text { do } \\
\text { volume abaixo de } 100 \text { mil } \\
\text { UFC/mL. }\end{array}$ & Sim \\
\hline $\begin{array}{l}\text { 4) Houve melhoria na remuneração por } \\
\text { qualidade do leite vendido para a Danone? } \\
\text { Padrão de resposta: SIM/NÃO/EM PARTES. }\end{array}$ & Sim & $\begin{array}{l}\text { Sim, teve o contrato feito com a } \\
\text { Danone que tem um preço } \\
\text { diferenciado. }\end{array}$ & Sim \\
\hline $\begin{array}{l}\text { 5) Qual foi a aceitação dos funcionários } \\
\text { quanto à mudança de procedimentos: } \\
\text { Pagamento pela qualidade, Check-list de } \\
\text { campo, check-list de caminhão, aumento de } \\
\text { amostragem, adequação das análises de } \\
\text { recepção de leite e treinamentos. Padrão } \\
\text { de resposta: MUITO } \\
\text { BOA/BOA/RAZOAVEL/FRACA/RUIM }\end{array}$ & Muito boa & $\begin{array}{l}\text { Razoável, pois no inicio foi difícil } \\
\text { porque eram muita amostras de } \\
\text { leite a serem coletadas, muitas } \\
\text { perguntas nos check-list e os } \\
\text { motoristas respondiam: "pra que } \\
\text { fazer tantas perguntas meu } \\
\text { caminhão está bom", a } \\
\text { repercussão no campo e } \\
\text { cooperativa sobre o pagamento } \\
\text { pela qualidade: "vai pagar por } \\
\text { qualidade os produtores vão } \\
\text { sair". Essas eram as conversas } \\
\text { que escutávamos mais com o } \\
\text { tempo foram acostumando e } \\
\text { aceitando a idéia. }\end{array}$ & Razoável \\
\hline
\end{tabular}


Quadro 4: Respostas das cooperativas ao questionário de avaliação do programa (conclusão).

\begin{tabular}{|c|c|c|c|}
\hline $\begin{array}{l}\text { 6) Qual foi a aceitação dos produtores } \\
\text { quanto ao pagamento pela qualidade do } \\
\text { leite, treinamento leite legal e aplicação do } \\
\text { check-list de campo pelo técnico da } \\
\text { cooperativa? Padrão de resposta: MUITO } \\
\text { BOA/BOA/RAZOAVEL/FRACA/RUIM }\end{array}$ & Boa & $\begin{array}{l}\text { Boa, pois houveram produtores } \\
\text { que aceitaram bem, outros que } \\
\text { saíram devido ao pagamento por } \\
\text { qualidade, outros que } \\
\text { procuraram melhorar pra receber } \\
\text { maior bonificação. Entretanto } \\
\text { isso fez com que selecionasse o } \\
\text { perfil de produtores preocupados } \\
\text { com a melhoria da qualidade e } \\
\text { hoje temos produtores que } \\
\text { reclamam quando o resultado } \\
\text { fica acima de } 10 \mathrm{mil} \text { UFC/mL. }\end{array}$ & Razoável \\
\hline $\begin{array}{l}\text { 7) Qual foi a aceitação dos motoristas } \\
\text { quanto aos procedimentos de higiene na } \\
\text { coleta e treinamento de agente de coleta de } \\
\text { leite? Padrão de resposta: MUITO } \\
\text { BOA/BOA/RAZOAVEL/FRACA/RUIM }\end{array}$ & Boa & $\begin{array}{l}\text { Boa: Em torno de } 80 \% \text { dos } \\
\text { motoristas foram aprovados, } \\
\text { houve agente de coleta } \\
\text { dispensado por não atender os } \\
\text { novos procedimentos, assim } \\
\text { renovou-se o quadro de } \\
\text { motoristas da COOPAS. }\end{array}$ & Razoável \\
\hline $\begin{array}{l}\text { 8) Qual é sua avaliação de } 0 \text { a } 10 \text { para o } \\
\text { Qualileite da Danone: }\end{array}$ & 10 & $\begin{array}{l}\text { Pelo desenvolvimento do } \\
\text { trabalho e instruções } 10 .\end{array}$ & $\begin{array}{l}\text { Nota } 8 \text {. Um } \\
\text { programa bom mas não } \\
\text { implantamos totalmente }\end{array}$ \\
\hline $\begin{array}{l}\text { 9) Você recomendaria este programa para } \\
\text { outra cooperativa? Padrão de Resposta: } \\
\text { SIM/NÃO }\end{array}$ & Sim & $\begin{array}{l}\text { Sim, pois foi muito produtivo e } \\
\text { interessante. }\end{array}$ & Sim \\
\hline
\end{tabular}

A respeito de facilidades e conhecimentos adquiridos no programa, as cooperativas Corples e Coopas consideram que o programa trouxe muito aprendizado e as ferramentas mais importantes para a melhoria no desempenho das atividades foram os check-lists (Caminhão e Produtor), as visitas direcionadas a produtores não conforme, implantação do sistema de pagamento pela qualidade, treinamentos e gestão da informação.

Todas as cooperativas citaram que houve melhorias na qualidade do leite e com isso melhor remuneração do leite comprado pela Danone.

Sobre a aceitação dos funcionários quanto aos novos procedimentos implantados pelo programa, a Corples considerou que houve boa aceitação, entretanto a Coopas e a Cooperativa " $X$ " consideraram razoável a aceitação, principalmente no início, pois aumentaram à quantidade de amostras (produtor e 
caminhão), os trabalhos de gestão desses resultados foram intensificados e vinculados com os check-lists e principalmente houve uma certa insegurança de implantar um sistema de pagamento/penalização pela qualidade e perder grande parte dos produtores. Essa mesma insegurança foi sanada após a implantação do pagamento pela qualidade do leite que selecionou o perfil de produtores preocupados em melhorar a qualidade. Com isso, as cooperativas Coopas e Corples declararam que houve uma boa aceitação dos produtores diante as ferramentas implantadas no programa.

Em relação à aceitação dos motoristas às ferramentas do programa, a Coopas e a Corples consideraram "boa aceitação" e os motoristas que não se adequaram foram dispensados.

Com relação às notas que as cooperativas deram ao programa: A Coopas e Corples declararam nota 10 e a Cooperativa "X" nota 8. Todas elas recomendariam o programa para ser implantado em outras cooperativas.

\section{DISCUSSÃO}

Durante a implantação do programa Qualileite na Danone, a análise das três cooperativas participantes caracterizou dois casos de sucesso, Coopas e Corples, as quais os resultados quantitativos se destacaram positivamente diante dos passos adotados na metodologia de atuação do programa e qualitativamente houve uma boa avaliação diante do programa como um todo, especificamente diante a melhoria organizacional na aplicação das ferramentas adotadas no programa.

Entretanto, houve um caso no qual não houve sucesso na implantação, a Cooperativa "X", a qual não evoluiu no atendimento de ações e consequentemente não houve evolução nos resultados quantitativos na recepção de leite Danone, fator que levou ao rompimento do programa sem que o mesmo tenha sido totalmente implementado. Com isso, a avaliação qualitativa da cooperativa declarou que é um bom programa, mas ressaltou a falta de conclusão de todos os passos do Qualileite.

Diante deste fato, notou-se a necessidade de adotar critérios na seleção do perfil de cooperativas a serem selecionadas ao programa. Com isso, diversas regras foram criadas para avaliar o perfil da cooperativa e para exigir ferramentas básicas para implementação do programa por parte da Danone. Além disso, foi necessário 
firmar um contrato comercial constando as regras do programa, tabela de pagamento pela qualidade do leite e obrigações do fornecedor e do comprador.

No entanto, no decorrer da implantação do programa, constatou-se que o perfil da alta liderança da Cooperativa é um diferencial para o desenvolvimento ou estagnação das ações do programa. Isso quer dizer que a cooperativa precisa, em primeiro lugar, ter o comprometimento da alta diretoria e aderir às exigências do planejamento, como: aumento do número de amostras e análises mensais de produtor e caminhões, contratação de técnico para atuar no campo, disponibilizar um analista para coordenar internamente as ações do programa, entre outros.

Apesar de oferecer capacitações aos técnicos e funcionários envolvidos, notouse uma limitação na estrutura de governança, ou seja, embora o Presidente e a Diretoria estejam cientes da importância do programa, é preciso sensibilizar os demais colaboradores e, sobretudo, imprimir liderança e motivação no ambiente de trabalho. Caso contrário, a falta de comprometimento dos demais níveis - gerenciais e operacionais - dificultam o andamento das ações.

O Qualileite é uma trabalho no qual mesmo após a implementação da metodologia na cooperativa é necessário que haja um acompanhamento periódico, para que possa reavaliar os procedimentos segundo o ciclo PDCA, de modo que haja uma melhoria continua na gestão e em parâmetros objetivos de qualidade do leite e padronização das atividades com o objetivo de garantir que os desvios não voltem a ocorrer.

\section{CONCLUSÃO}

Diante das exigências em CBT e CCS apresentadas pela IN 62, no qual tem se tornado cada vez mais rígida, aliada à forte preocupação das indústrias em se adequarem à normativa e também adquirirem uma matéria prima de melhor qualidade, este programa tem grande relevância, à medida que visa capacitar e adequar produtores e cooperativas aos requisitos exigidos pela IN 62, beneficiando não apenas a Danone, mas a cadeia produtiva do leite como um todo. Além disso, o Programa Qualileite foi uma inovação do time de fomento da Danone e é pioneira entre as grandes empresas de captação de leite.

Através da implementação das ferramentas do programa e das etapas de diagnóstico, planejamento, ação, verificação, girando o ciclo de melhoria continua do 
PDCA, o Qualileite foi avaliado pelas respostas dos participantes no questionário de avaliação qualitativa, mostrando que aprimorou a gestão da qualidade das cooperativas participantes e aproximou o relacionamento entre cooperativas e Danone.

Houve evolução dos resultados de CBT dos produtores das cooperativas, entretanto, devido ao perfil de produtores e estrutura de cada cooperativa, a efetividade foi diferente para cada uma delas. No que diz respeito aos resultados da carga de leite das cooperativas na recepção Danone, houve melhoria nos resultados da Coopas e Corples, comprovando a efetividade do Qualileite em obter leite com melhor qualidade de seus fornecedores, trazendo melhorias em toda a cadeia do leite.

Ambas as Cooperativas atendem o limite da IN 62 em CBT, ou seja, possuem média geométrica trimestral menor que $300.000 \mathrm{UFC} / \mathrm{mL}$, entretanto, apenas a Coopas está preparada para o limite que entrará em vigor em 2018 (menor que 100.000 UFC/mL).

Portanto, para as cooperativas almejarem a excelência na qualidade e o atendimento da IN 62 em 2018, muito trabalho ainda deve ser feito, com foco em orientação aos produtores de leite, com trabalho próximo de acompanhamento, englobando nos objetivos a melhoria e atendimento de todos os parâmetros exigidos nesta normativa. 


\section{REFERÊNCIAS}

ABNT NBR ISSO 22000; Associação Brasileira de normas técnicas; Sistemas de Gestão da Segurança de Alimentos - Requisitos para qualquer organização na cadeia produtiva de alimentos. 2006. 35 paginas. ICS 67.020 .

ASSUMPÇÃO, M. R. P. Reflexões para Construção de Metodologia para Desenvolvimento Sustentável na Cadeia de Suprimento: Adendo a relatório técnico apresentado à FAPESP - Departamento de Engenharia de Produção, Universidade Federal de São Carlos. São Carlos, 2002.57 p.

BRASIL. Ministério da Agricultura e Abastecimento. Portaria n. 46, de 10 de fevereiro de 1998. Institui o sistema de análise de perigos e pontos críticos de controle: APPCC a ser implantado nas indústrias de produtos de origem animal. Diário Oficial da União, Brasília, DF, 10 fev. 1998. Seção

BRASIL. Instrução Normativa ${ }^{\circ} 51$, de 18 de setembro de 2002. Ministério de Agricultura, Pecuária e Abastecimento. Aprova os Regulamentos Técnicos de Produção, Identidade e Qualidade do Leite tipo A, do Leite tipo B, do Leite tipo C, do Leite Pasteurizado e do Leite Cru Refrigerado e o Regulamento Técnico da Coleta de Leite Cru Refrigerado e seu Transporte a Granel. Publicado no Diário Oficial da União de 20/09/2002, Seção 1 , Página 13.

BRASIL. Instrução normativa n. 62, de 29 de dezembro de 2011. Ministério de Agricultura, Pecuária e Abastecimento. Atualiza a IN nº 51. Diário Oficial da União, 30 dez. 2011. Disponível em:<http://www.in.gov.br/visualiza/index.jsp?data=30/12/2011\&jornal=1\&pagina=6\&t otalArquivos=160>. Acesso em: 27 jan. 2014.

BRASIL. Resolução DIPOA - 10. Institui o Programa Genérico de Procedimentos Padrão de Higiene Operacional - PPHO, A ser utilizado nos estabelecimentos de Leite e Derivados que funcionam sob o regime de Inspeção Federal, como etapa preliminar e essencial dos programas de segurança alimentar do tipo APPCC (Análise de Perigos e Pontos Críticos de Controle). de 22 de maio de 2003. Ministério da Agricultura, Pecuária e Abastecimento. Secretaria de Defesa Agropecuária. Departamento de Inspeção de Produtos de Origem Animal. Seção 1, P. 4. 2003.

BRASIL. Portaria No 1.428, de 26 de novembro de 1993. Regulamento Técnico para Inspeção Sanitária de Alimentos COD - 100 À 001.000. Disponível em: http://bvsms.saude.gov.br/bvs/saudelegis/gm/1993/prt1428 2611 1993.html.

Acessado em: 20/06/2016.

BRASIL. Ministério da Agricultura e Abastecimento. Diário Oficial da União - Seção 1. $\mathrm{N}^{\circ} 84$. Instrução Normativa $\mathrm{N}^{\circ} 7$ de 3 de maio de 2016.

BRITO, J. R. F. Boas Práticas Agropecuárias na produção de leite. In: BARBOSA, S.B.P., BATISTA, A.M.V., MONARDES, H. III Congresso Brasileiro de Qualidade do Leite. Recife: CCS Gráfica e Editora, 2008, v.1, p. 129-143 
BRITO M. A. et al. Estabilidade ao Alizarol. EMBRAPA Gado de Leite. Empresa Brasileira de Pesquisa Agropecuária. [20--?]. Disponível em:

<http://www.agencia.cnptia.embrapa.br/Agencia8/AG01/arvore/AG01_195_21720039 246.html> Acessado em: 12/03/2015.

CBQL; Conselho Brasileiro de Qualidade do Leite. Comitê de Equipamentos de Ordenha: recomendações do Comitê de Equipamentos/ Conselho Brasileiro de Qualidade do Leite - São Paulo: Quiron, 2002. 28p.; $21 \mathrm{~cm}$

CARPINETTI, L. C. R. Gestão da Qualidade: conceitos e técnicas. São Paulo SP Ed Atlas, 2010. 241p.

CAMPOS, V. F. Controle da Qualidade Total (no estilo japonês). Belo Horizonte. MG. Editora de Desenvolvimento Gerencial, 1999.

CASSOLI, L. D.; MACHADO, P. F. Manual de Instruções para Coleta e Envio de Amostras de Leite para Análise. 2006. Laboratório Credenciado na RBQL do Ministério da Agricultura, Pecuária e Abastecimento (MAPA). DISPONÍVEL EM: $<$ http://www.clinicadoleite.com.br/fazenda/B2B-

FazendasLocaweb/Biblioteca_de_arquivos_files/manual\%20de\%20procedimento\%20para\%20coleta \%20fazenda.pdf> ACESSADO EM 09/04/2016

CASSOLI, L. D. Validação da Metodologia de Citometria de Fluxo para avaliação da contagem bacteriana do leite cru. Dissertação (Mestrado). Escola Superior de Agricultura Luiz de Queiroz. Piracicaba, 46p. 2005.

DURR, J.W. Programa nacional de melhoria da qualidade do leite: uma oportunidade única. In: DURR, J.W., CARVALHO, M.P., SANTOS, M.V. O Compromisso com a Qualidade do Leite. Passo Fundo: Editora UPF, 2004, v.1, p. 38-55.

EMBRAPA GADO DE LEITE. Importância econômica. 2009. Disponível em: http://sistemasdeproducao.cnptia.embrapa.br/FontesHTML/Leite/LeiteSudeste/import ancia.html. Acesso em: 25 mar. 2015.

EMBRAPA GADO DE LEITE. Limpeza dos utensílios e equipamentos de ordenha. Disponível em: http://www.cnpgl.embrapa.br/sistemaproducao/book/export/html/283. Acessado em: 15/03/2016.

EMBRAPA; Boas práticas agropecuárias na produção leiteira - Parte I - Brasília, DF; 2005. 39 p. : il. - (Série Qualidade e segurança dos alimentos). PAS Campo Programa Alimentos Seguros, Setor Campo. Convênio CNI/SENAI/SEBRAE/EMBRAPA. ISBN 85-7383-320-3. Disponível em: http://www.agricultura.gov.br/arq_editor/5.pdf Acessado em: 21/02/2016.

FAO (Food and Agriculture Organization). Food Outlook. 2013. Milk and Milk Products. Disponível em: <HTTP://www.fao.org/>. Acessado em: 04/05/2016.

GONÇALVES, Paulo Sergio. Administração de materiais. 3. ed. Rio de Janeiro: Elsevier, 2010. 
HARDING, F. Milk quality. New York: Blackie Academic \& Professional, 1995, 165 p. Disponível em <http://link.springer.com/chapter/10.1007/978-1-4615-2195-2 6\#page1>. Acessado em: 09/02/2016.

IBGE, 2014. Quantidade de Leite Total. Disponível em: <http://www.sidra.ibge.gov.br/bda/tabela/listabl.asp?c=74\&z=t\&o=23>. Acessado em: 11 de abril de 2015.

IBGE, 2011. Produção da Pecuária Municipal. Disponível em <http://www.ibge.gov.br/home/estatistica/economia/ppm/2011/ Acessado em: 12/03/2016.

IBGE, 2015. Produção Animal no $4^{\circ}$ trimestre de 2014. Disponível em: <http://www.ibge.com.br/home/estatistica/indicadores/agropecuaria/producaoagropec uaria/abate-leite-couro-ovos_201404comentarios.pdf> . Acessado em: 11 de abril de 2015.

LEITE BRASIL. Associação Brasileira dos Produtores de Leite. Disponível em: <http://www.leitebrasil.org.br/> Acessado em: 12/12/2015.

MACHADO, P. M. Método de Análise e Soluções de Problemas de Mastite em Rebanhos Leiteiros. Clinica do Leite. Apresentado no $2^{\circ}$ Workshop Mastite. 2014

MALHORTA, N. K. et al. Introdução à Pesquisa de Marketing. São Paulo: Pearson Prentice Hall, 2005.

MAPA. Ministério da Agricultura, Agropecuária e Abastecimento. Disponível em: <http://www.agricultura.gov.br/legislacao>. Acessado em 22/05/2013.

MARIANI, C.A; Método PDCA e ferramentas da qualidade no gerenciamento de processos industriais: um estudo de caso. RAI - Revista de Administração e Inovação, São Paulo, v. 2, n. 2, p. 110-126, 2005.

MARSHALL JUNIOR, I. et al. Gestão da Qualidade. Rio de Janeiro. Ed FGV, 2007. $196 p$.

MARTINS, R. T. Estudo de Caso sobre o uso de ferramentas de gestão da qualidade em uma empresa rural. Universidade de Brasilia UNB. Faculdade UNB Planaltina FUP. Brasilia DF. 2013.

Organização Pan-Americana da Saúde. Higiene dos Alimentos - Textos Básicos; Agência Nacional de Vigilância Sanitária; Food and Agriculture Organization of the United Nations. - Brasília: Organização Pan-Americana da Saúde, 2006. 64 p.: il.

PACHECO, A. P. et al.. O ciclo PDCA na gestão do conhecimento.PPGEGC Universidade Federal de Santa Catarina. 2007. Disponível em: <http://www.isssbrasil.usp.br/isssbrasil/pdfs2/ana.pdf> Acessado em 19/5/2013. 
PHILIPPI, S. T.; LATTERZA, A. R.; CRUZ, A. T. R.; RIBEIRO, L. C. Pirâmide alimentar adaptada: guia para escolha dos alimentos. Rev. Nutr. 1999, vol.12, n.1, pp. 65-80. Disponível em: <http://dx.doi.org/10.1590/S1415-52731999000100006>. Acessado em:01/02/2016.

PAS Campo - Programa Alimentos Seguros, Setor Campo. Boas práticas agropecuárias na produção leiteira - Parte II. - Brasília, DF : Embrapa Transferência de Tecnologia, 2005. 20 p.

PASSOS, T. Microrganismos Psicrotróficos no leite. Artigo técnico ReHAgro. 17/10/2003. Disponível em:

http://rehagro.com.br/plus/modulos/noticias/ler.php?cdnoticia=688. Acessado em: 18/06/2016.

PINTO, C.L.; MARTINS, M. L.; VANETTI, M. C. D. Qualidade Microbiológica de Leite Cru Refrigerado e Isolamento de Bactérias Psicrotróficas Proteolíticas. Ciênc. Tecnol. Aliment., Campinas, 26(3): 645-651, jul.-set. 2006.

POZO, Hamilton. Administração de recursos materiais e patrimoniais: uma abordagem logística. 2. ed. São Paulo: Atlas, 2002.

QUEIROZ, V.M; ANDRADE, H.V; Importância das Ferramentas da Qualidade BPF/APPCC no Controle dos Perigos nos Alimentos em um Laticínio. FAZUFaculdades Associadas de Uberaba, Av. do Tutunas, 720 - CEP 38061-500, Uberaba - MG. Cadernos de Pós Graduação da FAZU, V. 1 (2010).

RIBEIRO-FURTINI, L.L; ABREU, L.R; Utilização de APPCC na Indústria de Alimentos. Ciênc. agrotec., Lavras, v. 30, n. 2, p. 358-363, mar./abr., 2006 RAMOS, T. M. et al. Gestão de Qualidade em Pequenas Empresas Processadoras de Leite: Situação Atual e Recomendações. Ver. Inst. Latic. "Cândido Tostes", Maio/Jun, n 374, 65, 2010. P. 17-25.

ROSA, et al., Boas Práticas de Manejo - Ordenha. Jaboticabal : Funep, 200943 p. : il. ISBN 978-85-7805-033-7. Disponível em:

http://www.agricultura.gov.br/arq editor/file/Aniamal/Bemestaranimal/manual ordenha.pdf Acessado em: 21/02/2016

SANTOS, M. V. Boas práticas de produção associadas à higiene de ordenha e qualidade do leite. In: O Brasil e a nova era do mercado do leite - Compreender para competir. Piracicaba-SP : Agripoint Ltda, 2007, v.1, p. 135-154.

SANTOS, M. V.; FONSECA, L. F. L. Estratégias para o controle de mastite e melhoria da qualidade do leite. Pirassununga, SP: Ed. Dos Autores, 2007.

SANTOS, M. V. Padrões mínimos de qualidade do leite: é necessária uma nova revisão da IN 62?. MilkPoint. Postado em 28/08/2014. Disponível em:

<http://www.milkpoint.com.br/mypoint/6239/p_padroes_minimos_de_qualidade_do_I eite_e_necessaria_uma_nova_revisao_da_in_62_5597.aspx> Acessado em $01 / 03 / 2015$ 
SELEME, R.; STANDLER, H. Controle da Qualidade: As Ferramentas Essenciais. Curitiba: IBPEX. 2008

SIMÕES, L.; RIBEIRO, C. M. O Ciclo PDCA como ferramenta da Qualidade Total. In: Encontro Cientifico Unisalesiano. 2009. Disponível em:

http://www.unisalesiano.br/pdfs2/ana.pdf Acessado em: 20/08/2013.

SCALCO, A. R.; TOLEDO, J. C. Gestão da qualidade em laticínios do estado de São Paulo: situação atual e recomendações. Revista de Administração, São Paulo v.37, n.2, p.17-25, abril/junho 2002

TEIXEIRA, S. R.; RIBEIRO, M. T. Instrução técnica para o produtor de leite. Qualidade e Segurança Alimentar. N²2. EMBRAPA. Empresa Brasileira de Pesquisa Agropecuária. DEZ/2000.

TOLEDO, et al.; Coordenação da Qualidade em Cadeias de produção; Estrutura e Método para Cadeias Agroalimentares. Gestão e Produção. v.11, n.3, p.355-372, set.-dez. 2004

USDA. United States Department of Agriculture. PSD: production, supply and distribution online. Reports. Washington, 2014. Disponível em: <http:// www.fas.usda.gov/psdonline/download/psd_dairy_csv.zip>. Acesso em: 01/08/2014.

VALOR ECONÔMICO. Consumo de lácteos perde fôlego no pais. Publicado em 08/12/2015. Disponível em: <http://www.valor.com.br/agro/4345974/consumo-delacteos-perde-folego-no-pais> Acessado em: 22/04/2016.

ZANIOLO, J. A. Implantação do Sistema APPCC na Produção de Qualijo Tipo Muçarela. Enciclopédia Biosfera, Centro Científico Conhecer - Goiânia, v.11 n.22; p. 2015.

ZAFALON, et al., Boas práticas de ordenha [Recurso eletrônico]. São Carlos: Embrapa Pecuária Sudeste, 2008. Disponível em: http://central3.to.gov.br/arquivo/228631/ Acessado em: 07/03/2016.

YIN, Robert K. Estudo de Casos: Planejamento e Métodos. São Paulo: Editora Bookman, 212p, 2005. 